\title{
The Henson Gletscher Formation, North Greenland, and its bearing on the global Cambrian Series 2-Series 3 boundary
}

\author{
GERD GEYER \& JOHN S. PEEL
}

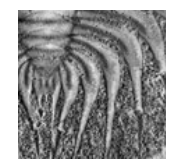

\begin{abstract}
The Henson Gletscher Formation of North Greenland yields moderately diverse trilobite faunas which bracket the Cambrian Series 2-Series 3 boundary interval. A number of the trilobite taxa permit correlation into other parts of Laurentia and to other Cambrian continents, thus enhancing correlation within this stratigraphical interval of the traditional Lower-Middle Cambrian boundary. In particular, the occurrence of Ovatoryctocara granulata and O. yaxiensis substantially improves the intercontinental recognition of the $O$. granulata level, a prime GSSP candidate. In contrast, the level with Oryctocephalus indicus cannot be located in a number of Cambrian continents with sufficient precision, making this level unsuitable for the definition of a GSSP for the base of the Cambrian Series 3 and Stage 5. Further support for the correlation potential of the base of the range of Ovatoryctocara granulata comes from recent carbon isotope studies that indicate a striking negative excursion in sections of South China (ROECE event) that probably coincides with similar excursions in Laurentia. Four new trilobite species are described: Zacanthopsis blakeri sp. nov., Protoryctocephalus arcticus sp. nov., Eoptychoparia pearylandica sp. nov. and Onchocephalus? freucheni sp. nov. - Key words: Lower-Middle Cambrian boundary, trilobite biostratigraphy, global correlation, GSSP, Henson Gletscher Formation, Greenland.
\end{abstract}

GeYer, G. \& PEEL, J.S. 2011. The Henson Gletscher Formation, North Greenland, and its bearing on the global Cambrian Series 2-Series 3 boundary. Bulletin of Geosciences 86(3), 465-534 (22 figures). Czech Geological Survey, Prague. ISSN 1214-1119. Manuscript received December 30, 2010; accepted in revised form September 2, 2011; published online September 23, 2011; issued September 30, 2011.

Gerd Geyer, Department of Earth Sciences (Palaeobiology), Uppsala University, Villavägen 16, SE-752 36 Uppsala, Sweden, and Bayerisches Landesamt für Umwelt, Hans-Högn-Straße 12, 95030 Hof, Germany; gerd.geyer@geo.uu.se - John S. Peel, Department of Earth Sciences (Palaeobiology), Uppsala University, Villavägen 16, SE-752 36 Uppsala, Sweden; john.peel@pal.uu.se

Discussions of the traditional Lower-Middle Cambrian boundary and the newly proposed base of the global Series 3 and Stage 5 of the Cambrian have been in focus since at least 1971, as witnessed by the unpublished correspondence of the members of a semi-formal Working Group on the Lower-Middle Cambrian boundary (1971) and the protocols of the International Subcommission on Cambrian Stratigraphy (1974). While various scientific difficulties were quickly recognized, the issue was not addressed in much detail before the Cambrian subdivision initiative of the ISCS started in 1999 (Geyer \& Shergold 2000). Discussions in the ISCS indicated a general agreement that historical perspectives should not necessarily have priority in finding a practical solution. A novel approach for the definition of a GSSP for the base of Series 3 and Stage 5 concerned a species referred to Oryctocephalus indicus. Although a key species, it had not played a major role in Lower-Middle Cambrian boundary discussions prior to its proposal as a suitable marker for the base of a Middle Cambrian series (Yuan et al. 1997, Sundberg et al. 1999, Peng et al. 2000, McCollum \& Sundberg 2002, Sundberg \& McCollum 2003, Sundberg 2009).

In this paper we show that the level with Oryctocephalus indicus cannot be located precisely on a number of Cambrian continents, thus making it unsuitable for defining a GSSP for the base of the Cambrian Series 3 and Stage 5.

In addition, we demonstrate that the general occurrence of Ovatoryctocara granulata and O. yaxiensis in North Greenland substantially improves recognition of the O. granulata level on a global scale. Auxiliary trilobite species enable a relatively fine-scaled global correlation of this stratigraphic level into nearly all Cambrian continents in which the traditional Lower-Middle Cambrian transition is preserved in biostratigraphically resolvable strata. Thus, we strongly recommend utilization of the 
Ovatoryctocara granulata level to define the base of the Cambrian Series 3 and Stage 5 on a global scale, and suggest that the Molodo River section in northeastern Siberia and the Balang section in Guizhou, P.R. of China, currently provide the best perspectives for placement of the GSSP.

The background to this discussion is provided by the fauna of the Henson Gletscher Formation of North Greenland (Fig. 1). In total, almost 40 different trilobites can be recognized from the relevant stratigraphic interval of the Henson Gletscher Formation. Most of these were described by Blaker \& Peel (1997) and about 15 species have particular implications for intercontinental biostratigraphy. A large number of species allow direct correlation into other regions of Laurentia, but these species and their meaning are not discussed herein in detail. Instead, we will focus on those species which permit a correlation into other Cambrian continents.

\section{The Henson Gletscher Formation of North Greenland}

The oldest richly fossiliferous Cambrian strata in North Greenland are siliciclastic sediments of the Buen Formation which record a major expansion of the developing transarctic Franklinian Basin (Higgins et al. 1991; Ineson \& Peel 1997, from which the following account is briefly summarized). Lower beds of the formation preserve the Sirius Passet Lagerstätte of Montezuman (Nevadella Zone) age (Cambrian Series 2, Stage 3) with Buenellus higginsi (Conway Morris et al. 1987, Blaker \& Peel 1997, Babcock \& Peel 2007, Peel 2010, Ineson \& Peel 2011) but higher levels of the formation yield Limniphacos, Mesolenellus and Olenellus (Blaker \& Peel 1997).

The Buen Formation is overlain abruptly by lower Cambrian carbonates which represent the first stage in the development of a major carbonate platform that extended across North Greenland in the early Palaeozoic. In the Cambrian, a restricted shallow water carbonate platform passed northwards into a deeper water outer shelf which itself gave way farther north to a deep water trough. In the west the development of the carbonate sequence was aggradational, but in central and eastern areas early Cambrian-earliest Ordovician sediments form part of northwards prograding succession referred to the Brønlund Fjord Group (which includes the Henson Gletscher Formation; Fig. 1B) and the overlying Tavsens Iskappe Group. The Brønlund Fjord and Tavsens Iskappe groups are dominated by deeper water carbonates and siliciclastic sediments, characteristically with units of dark carbonates and shales separated by carbonate turbidites and mass flow deposits. The carbonate turbidites and mass flow deposits represent periods of active progradation during periods of relative sea level highstand whereas the dark carbonates and shales represent periods of relative lowstand. The alternation of highstand and lowstand deposition is reflected in the lithostratigraphic subdivision of both groups, such that the dark, recessive sediments of the Henson Gletscher Formation represents a period of lowstand between prominent, pale weathering, prograding highstand deposits of the Aftenstjernes $\varnothing$ and Sydpasset formations (Fig. 1B).

The Henson Gletscher Formation is composed of dark, recessive, shaly weathering, bituminous and cherty limestones, dolostones and mudstones with a strongly sooty aspect. A middle member of pale weathering, cream, finegrained sandstones thins towards the north but south-eastwards the Henson Gletscher Formation grades into the Sæterdal Formation that is composed almost entirely of such sandstones. Coarse skeletal packstones and grainstones are known from the lower part of the Henson Gletscher Formation at Løndal (Fig. 1D, locality 6). Thin mass flow breccias composed of dark carbonate clasts identical with surrounding lithologies occur sporadically. The Henson Gletscher Formation is $62 \mathrm{~m}$ thick at its type locality in southern Lauge Koch Land (Fig. 1D, E, locality 2), but thickens to $112 \mathrm{~m}$ in southern Freuchen Land (Fig. 1D, E, locality 1). Along the northern coast of Greenland, the formation varies in thickness between 20-60 m, but attains $90 \mathrm{~m}$ in northern Nyeboe Land, to the northwest of the present study area.

Fossils are scattered throughout the formation except for the barren sandstone units. Fossils usually appear in oligospecific associations of mostly trilobites with some inarticulate brachiopod and helcionelloid species, often as dense accumulations of mostly disarticulated sclerites on bedding planes of thin, platy, argillaceous limestones. Such associations are generally rich in immature individuals, but usually have only disarticulated sclerites and rarely more-or-less complete carcasses. These taphonomic conditions indicate that these studied horizons were affected by occasional rapid burial and intermittent short-distance transport.

The Henson Gletscher Formation includes trilobite faunas with a strongly Laurentian aspect, but also includes faunal elements known from other Cambrian palaeogeographic regions such as the Siberian Platform, the Sayan-Altay Fold belt, and the Yangtze/South China Platform. The biostratigraphic zones recognized from the Henson Gletscher Formation range from the traditional latest Early Cambrian Olenellus Zone to the late Mid Cambrian Ptychagnostus gibbus Zone (Drumian Stage) (Palmer \& Peel 1979; Robison 1984; Blaker 1986, 1991; Peel 1994; Blaker \& Peel 1997). Hence, according to the orthodox biostratigraphical zonation of Laurentia, the Olenellus, Plagiura-Poliella, Albertella, Glossopleura, Ptychagnostus atavus and Ptychagnostus gibbus zones are represented if the faunal succession is complete, thus characterizing a Dyeran through Marjuman succession. 
A

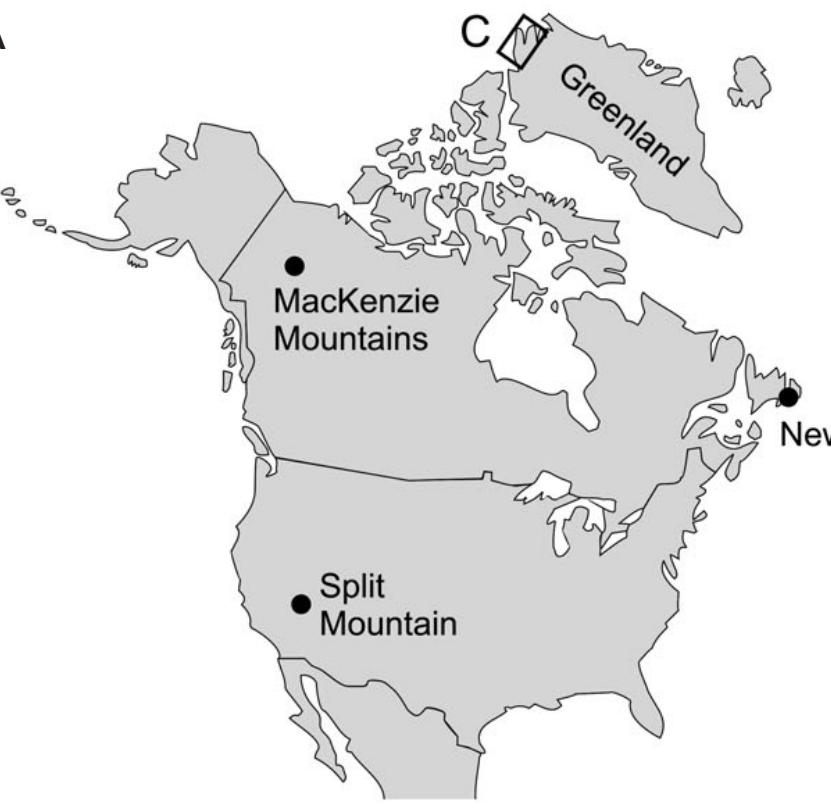

C

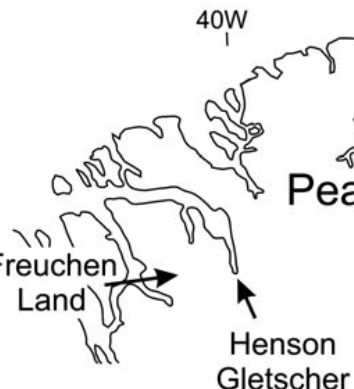

Gletscher

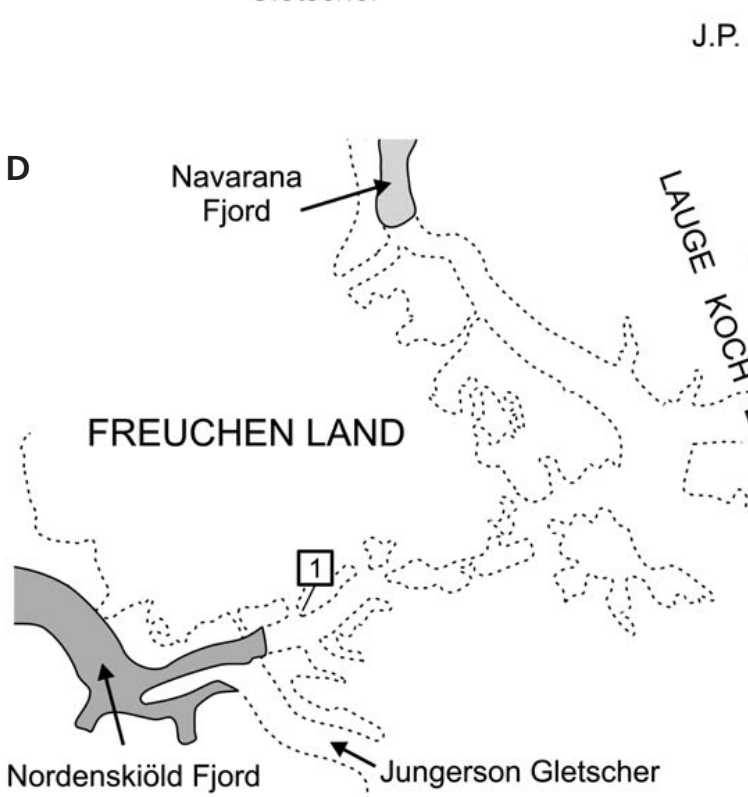

B

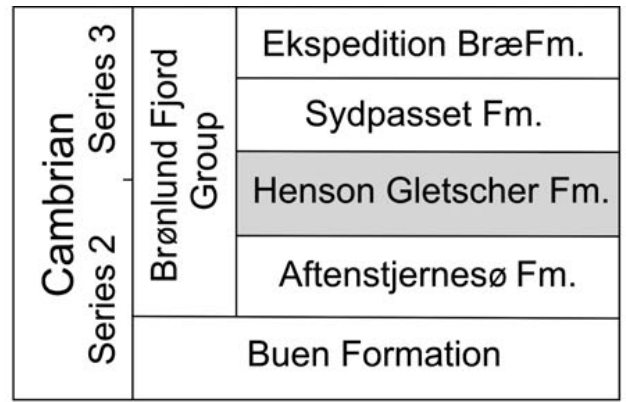

Newfoundland

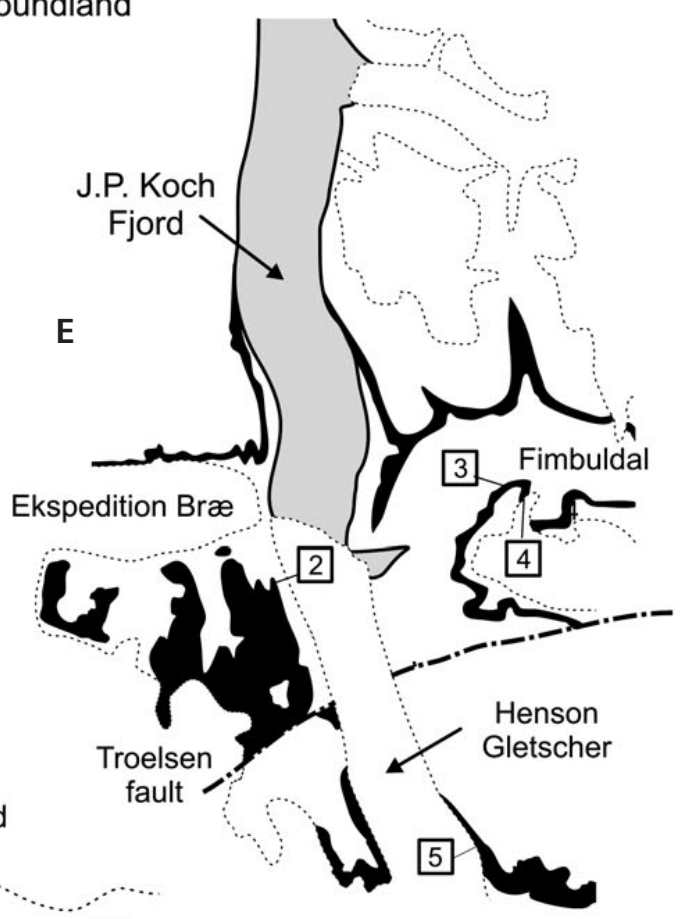

Figure 1. Geographical and geological setting of the Henson Gletscher Formation. $\bullet$ A - North America with the framed outcrop area in North Greenland (enlarged in C) and occurrences of Ovatoryctocara and Oryctocephalus indicus in North America (black dots). • B - lithostratigraphical nomenclature of Lower and lower Middle Cambrian units (Cambrian Series 2 and part of 3) in North Greenland. $\bullet$ C - sketch map of the Peary Land region showing the position of Freuchen Land and Henson Gletscher. • D - principal Henson Gletscher Formation localities (1-6) in the Freuchen Land - southwestern Peary Land area. 1 - reference section in Freuchen Land (see Fig. 4); 2 - type section in Lauge Koch Land; 3, 4 - Fimbuldal (see Fig. 5); 5 - head of Henson Gletscher; 6 - Løndal (see Fig. 6). $\bullet$ E - outcrops of the Brønlund Fjord Group (black) in the Henson Gletscher and Fimbuldal areas showing localities as in D. 


\section{Stratigraphic constraints of the Lower-Middle Cambrian boundary interval in the Henson Gletscher Formation}

Most of the Henson Gletscher Formation (Figs 2-6) yields trilobites bracketing the traditional Lower-Middle Cambrian boundary interval. Investigation of earlier collections studied by Blaker (1986) and Blaker \& Peel (1997), and new collections made by J.S. Peel and P. Frykman in 2006, indicate that the characteristic oryctocephaloid-dominated assemblages range from the lower (but not lowest) up to the higher part of the Henson Gletscher Formation and that this part of the unit was deposited within a comparatively short interval. This interval also brackets the middle member of slightly dolomitic sandstones and siltstones so that a considerable or, at any rate, recognizable hiatus does not exist. Such a discontinuity within the sandstone was suggested by Palmer \& Peel (1979). It was equated by Ineson \& Peel (1980) with the Hawke Bay Event, which had been interpreted by Palmer \& James (1980) as a circum-Iapetus eustatic event due to larger scale tectonic movements. Nevertheless, the sandstone member with its strongly variable, but south and eastward increasing thickness indicates short-term changes in the depositional processes, with lowstand conditions limiting carbonate production on the shallow water platform and the siliciclastic sands bypassing the platform to the off-platform regime (Ineson \& Peel 1997). The mass flow horizon, with fossiliferous clasts of limestone/dolostone, and associated strata in the upper part of the Henson Gletscher Formation suggest a possible disruption in sedimentation. Clast lithologies, however, are typical Henson Gletscher Formation lithologies, indicating derivation from the slope (Fig. 3). Although the faunal elements suggest that only a short interval is missing at this level, the trilobites indicate a recognizable break between the Ovatoryctocara-dominated carbonates below and faunas with new ptychoparioids and with Oryctocephalus, above (see below under Fimbuldal section).

Biostratigraphically useful collections from the Henson Gletscher Formation discussed herein are derived from four main areas (Fig. 1D, E): Freuchen Land (Fig. 1D, locality 1); Lauge Koch Land (Fig. 1D, E, locality 2); Fimbuldal in westernmost Peary Land (Fig. 1D, E localities 3 and 4); Løndal, in Peary Land to the east of Hans Tavsen Iskappe (Fig. 1D, locality 6). Additional relevant collections were made at the head of Henson Gletscher (Fig. 1D, E, locality 5; locality 4 of Blaker \& Peel 1997, fig. 8A).

Freuchen Land. - In southern Freuchen Land $\left(82^{\circ} 09^{\prime} \mathrm{N}\right.$, $42^{\circ} 25^{\prime} \mathrm{W}$; Fig. 1D, locality 1 ; also locality 1 of Blaker \& Peel 1997, figs 8A, 10) fossils were collected from a nunatak forming a reference section $112 \mathrm{~m}$ thick described by Ineson \& Peel (1997, figs 21, 32, 33). The often fairly rich assemblages from Freuchen Land (Fig. 1D, locality 1; Fig. 4) indicate a distinct overlap of Olenellus and Ovatoryctocara. Olenellus cf. truemani occurs from the lowest fossiliferous samples well above the base of the Henson Gletscher Formation, but below the tremendously thick ( $c a$ $70 \mathrm{~m}$ thick) and barren sandstone member, up to the topmost sample well above the sandstone member. Eoagnostus roddyi is present in some samples below the sandstone member but was not found in the lowermost assemblages. Remarkably, Arthricocephalus is known from samples within this stratigraphic interval (Lane et al. 1988, Blaker \& Peel 1997), together with specimens identified as Lancastria cf. plana and Haliplanktos jishouensis, although Arthricocephalus was not found to co-occur in associations with Olenellus cf. truemani and Eoagnostus roddyi. Ogygopsis typicalis and Zacanthopsis spp., as well as the earliest ptychoparioid specimens, have their lowest occurrences a short distance below the sandstone member but persist above it.

Samples above the sandstones yield Bonnia cf. brennus as well as Ovatoryctocara granulata and O. yaxiensis, together with Pagetides elegans and Onchocephalus? freucheni, indicating that a biostratigraphical gap is not present in the section up to this horizon. In particular, the occurrence of Pagetides elegans indicates a higher biostratigraphical level.

Lauge Koch Land. - The type section of the Henson Gletscher in southern Lauge Koch Land (82 ${ }^{\circ} 10^{\prime} \mathrm{N}, 4^{\circ} 24^{\prime} \mathrm{W}$; Fig. 1D, E locality 2) was described in detail by Ineson \& Peel (1997, figs 25, 31) with a measured thickness of $62 \mathrm{~m}$. Blaker \& Peel (1997, fig. 9) recorded Oryctocephalus vicinus (= Protoryctocephalus arcticus sp. nov.), Lancastria plana, Pagetides elegans and Ovatoryctocara sp. A from small collections above the medial sandstone interval, but the section has not been well collected.

Fimbuldal. - Two sections were sampled on the southern side of Fimbuldal in Peary Land, northeast of the snout of Henson Gletscher. Locality $4\left(82^{\circ} 17.5^{\prime} \mathrm{N}, 39^{\circ} 41^{\prime} \mathrm{W}\right.$; Fig. 1D, E; also locality 5 of Blaker \& Peel 1997, figs 8A, 9) is located above the western side of a small glacier tongue, about $0.5 \mathrm{~km}$ southeast of the new section $\left(82^{\circ} 17.7^{\prime} \mathrm{N}\right.$, $39^{\circ} 42^{\prime} \mathrm{W}$; locality 3 ) sampled in 2006 . Information from the two sections is combined in Fig. 5.

The samples from Fimbuldal include paucispecific assemblages from below the sandstone member, which include Olenellus cf. truemani and Kootenia sagena, as well as Ogygopsis, although this interval was subject only to cursory collection. The lowermost samples from above the sandstone member, recollected in some detail during 2006 (Fig. 5), have assemblages with Neopagetina rjonsnitzkii, Olenellus, Protoryctocephalus, and two species of Ovatoryctocara (amongst others). Although the 

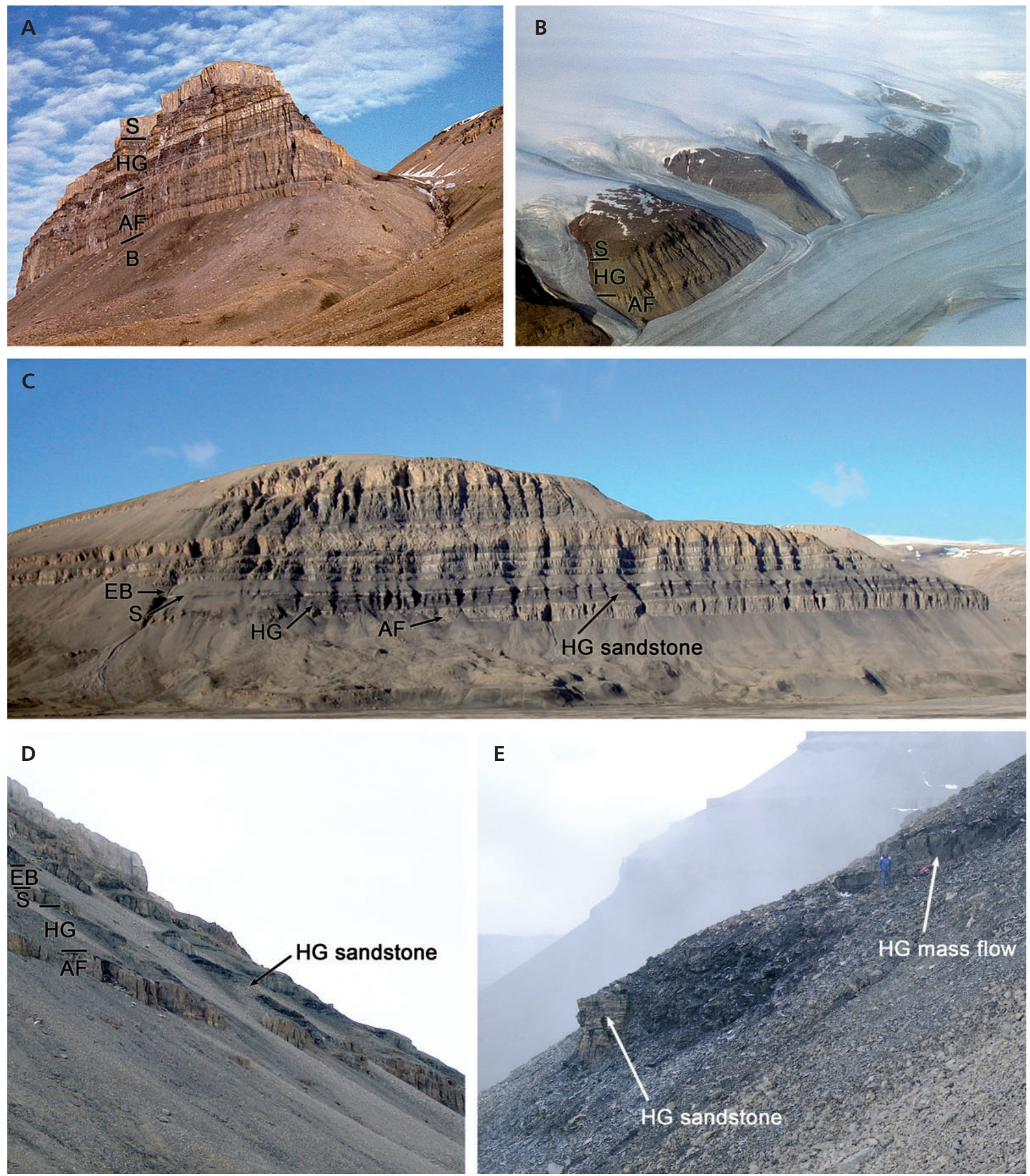

Figure 2. Henson Gletscher Formation sections in North Greenland. • A - type section of the Brønlund Fjord Group and Henson Gletscher Formation in southern Lauge Koch Land (Fig. 1D, E, locality 2), viewed from the northeast; the measured section (Fig. 3) is located behind the spur. Note the white sandstone unit within the Henson Gletscher Formation. $\bullet$ B - nunatak (left) in southern Freuchen Land exposing the reference section of the Henson Gletscher Formation adjacent to the tributary glacier margin (Fig. 1D, locality 1), aerial view from the south. $\bullet^{C}$ - north side of Fimbuldal viewed from Fimbuldal locality 3 (Fig. 1D, E). D - south side of Fimbuldal, locality 3 (Fig. 1D, E), looking west. E - south side of Fimbuldal, locality 3 (Fig. 1D, E), looking east. Abbreviations: AF - Aftenstjernesø Formation; B - Buen Formation; EB - Ekspeditionsbræ Formation; HG - Henson Gletscher Formation; $\mathrm{S}$ - Sydpasset Formation. 


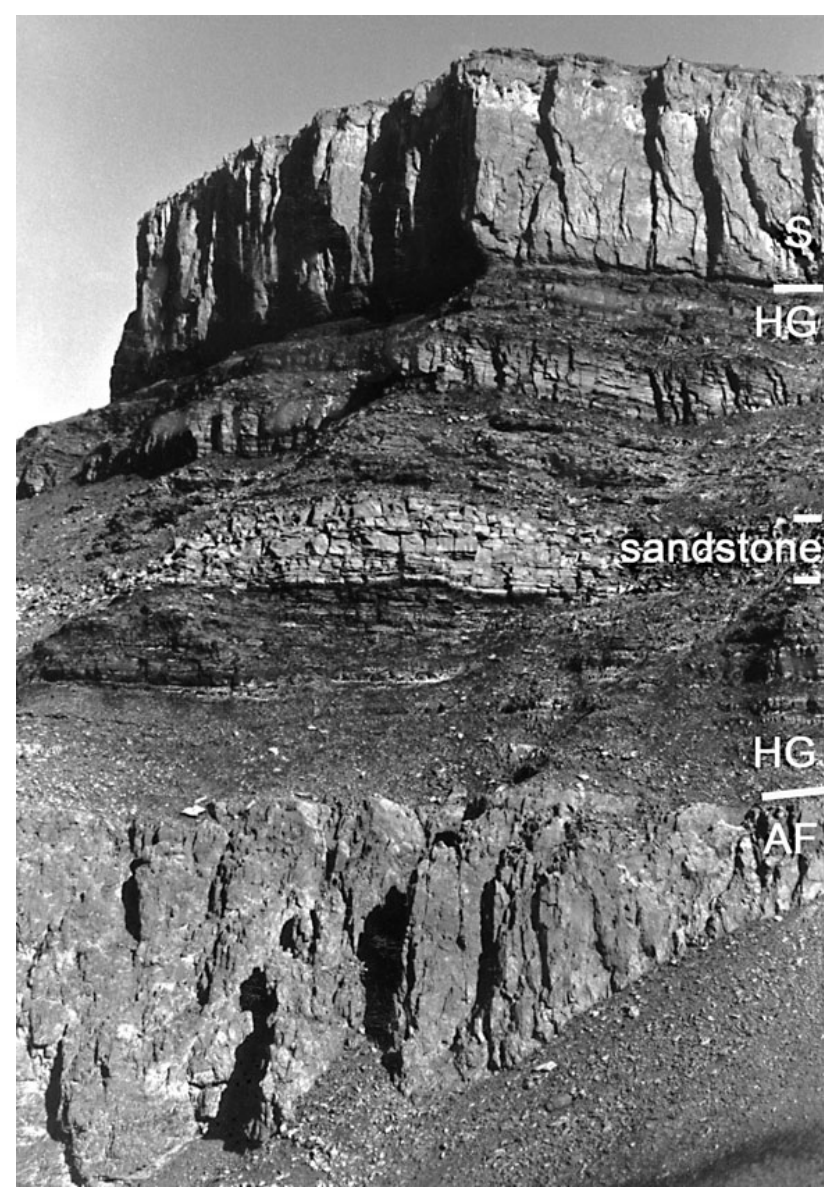

Figure 3. Type section of Henson Gletscher Formation (thickness $62 \mathrm{~m}$ ) in Lauge Koch Land (Fig. 1D, E, locality 2; Fig. 2A). Abbreviations: AF - Aftenstjernesø Formation; HG - Henson Gletscher Formation; $\mathrm{S}$ - Sydpasset Formation.

Olenellus species is only present as immature cephala, there is no recognizable character that suggests another identity than $O$. cf. truemani (see Fig. 7 below). Olenellus, however, is not present in the highest part of the interval where assemblages are characterized by ptychoparioid trilobites. These mainly occur in a resistant unit including sandy carbonates, a thin mass flow deposit composed of dark carbonates, and overlying bioclastic limestones (section height $48-52 \mathrm{~m}$ ). A sample from the matrix of this mass flow deposit yielded a somewhat different fauna with Olenoides cf. procerus and Oryctocephalus cf. indicus (Fig. 19A). Unfortunately, both forms are known only from single cranidia so that the identifications must remain tentative despite good preservation (Fig. 5).

While the faunal turnover evident in the Freuchen Land section is not well documented in Fimbuldal on account of the scarcity of fossil material from below the sandstone, there is no evidence for a distinct hiatus over the main sandstone interval. The abundance of oryctocephalids may be partly controlled by facies, but the appearance of $O$ vatoryctocara reflects a biostratigraphical change since similar facies occur both below and above the sandstone unit. The abrupt disappearance of most oryctocephalids towards the sandy limestone and mass flow deposit may involve a brief discontinuity followed by down slope transport of sediment yielding the Oryctocephalus cf. indicus association.

Head of Henson Gletscher. - This section in southwest Peary Land, at the head of Henson Gletscher $\left(82^{\circ} 10^{\prime} \mathrm{N}\right.$, 3940` W; Fig. 1D, E, locality 5; Blaker \& Peel 1997, fig. 8A, locality 4 ) is dominated by sandstones witnessing the southward transition of the Henson Gletscher Formation into laterally equivalent sandstones of the Sæterdal Formation. A lower unit of dark grey dolomites $(16 \mathrm{~m})$ yields Ogygopsis typicalis at $12 \mathrm{~m}$ above the base of the formation. Pale sandstones dominate the overlying $39 \mathrm{~m}$ before a $4 \mathrm{~m}$ thick unit of mainly dark limestones yields Olenellus cf. truemani, Pagetides elegans, Bonnia brennus, Kootenia sp. indet. and ptychoparioids. Blaker \& Peel (1997) reported Ptychoparella sp. A from this level. Sandstones form the upper $13 \mathrm{~m}$ of the formation.

Løndal. - The succession in Løndal, in Peary Land to the east of Hans Tavsen Iskappe, $\left(82^{\circ} 17.5^{\prime} \mathrm{N}, 37^{\circ} 03^{\prime} \mathrm{W}\right.$; Fig. 1D, locality 6; Blaker \& Peel 1997, figs 8A, 11) was illustrated by Ineson \& Peel (1997, fig. 58).

The Løndal section is about $45 \mathrm{~m}$ thick and yields oligospecific assemblages below the sandstone member (Fig. 6). These include Olenellus cf. truemani (Fig. 7), Ogygopsis batis, and ptychoparioid trilobites (in the upper part). Blaker \& Peel (1997) reported Arthricocephalus chauveaui to co-occur in this section with Eoagnostus roddyi, Ogygopsis typicalis, and Oryctocephalus vicinus below the sandstone member. However, the species of Arthricocephalus cannot be attributed to A. chauveaui with certainty, and the specimens described as Oryctocephalus vicinus are a new species described below as Protoryctocephalus arcticus.

The upper part of the section includes a $c a 1 \mathrm{~m}$ thick shaly limestone intercalation within the upper part of the sandstone member. This level yields Pagetides elegans and Bonnia brennus, together with Protoryctocephalus arcticus, Ovatoryctocara and ptychoparioids, a fauna that first appears above the sandstone unit in the Freuchen Land region. In Løndal, the sandstone succession ( $c a 19 \mathrm{~m}$ ) is less than one third of the thickness in Freuchen Land (Fig. 4).

\section{Henson Gletscher trilobites and their systematic affinities and stratigraphic correlatives}

Key taxa from the Henson Gletscher Formation discussed in this section are formally described under Systematic palaeontology, below. 


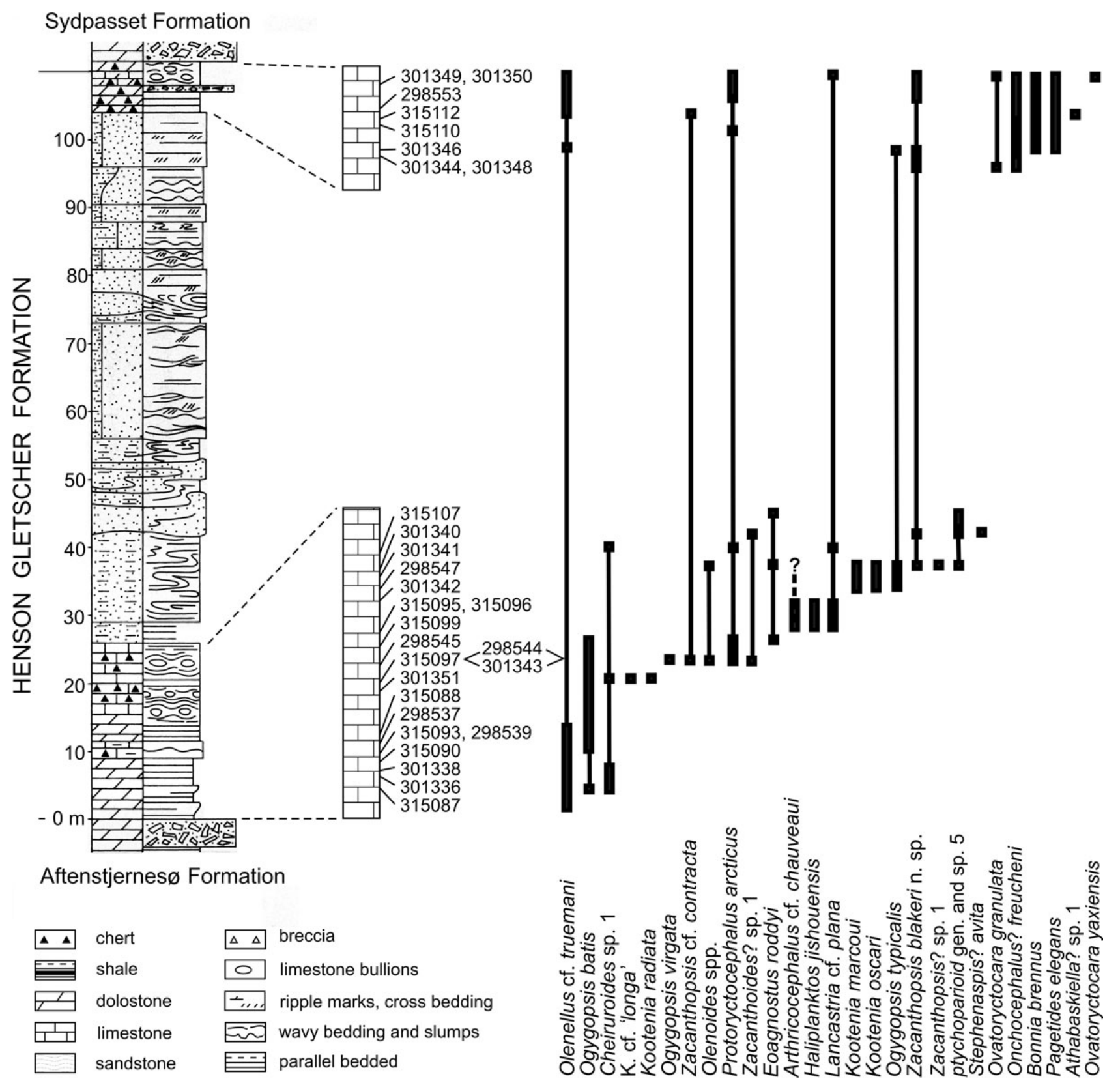

Figure 4. Lithologic profile showing distribution of GGU collections and trilobites within the Henson Gletscher Formation at locality 1 (Fig. 1D), Freuchen Land, North Greenland. Profile after Ineson \& Peel (1997).

Eoagnostus roddyi Resser \& Howell, 1938 (see Fig. 11, below) was first discovered in the Lower Cambrian Kinzers Shale of Pennsylvania where it co-occurs with Olenellus; it was subsequently described as Eoagnostus acrorhachis Rasetti \& Theokritoff, 1967 from the Taconic Sequence of the New York State. In the Henson Gletscher Formation, the species was discovered in samples from southern Freuchen Land (Fig. 1D, E, locality 1) and Løndal (Fig. 1D, E, locality 6). All occurrences are from below the sandstone member and together with material now identified as Protoryctocephalus arcticus sp. nov. and Arthricocephalus cf. chauveaui.
Several authors have referred to the immense variation in the cephalic morphology of the species and regarded it as a species of Peronopsis (Robison 1994, Blaker \& Peel 1997, Fletcher 2003). Such a morphologic concept requires synonymization of more than 10 previously recognized genera with Peronopsis and creates a genus which does not parallel other generic concepts of Cambrian trilobites. In the case of Eoagnostus Resser \& Howell, 1938, there is little doubt that the genera are closely related, and the variability in the distinctness of the anteroglabellar outline can be regarded as insufficient to distinguish the genus from 


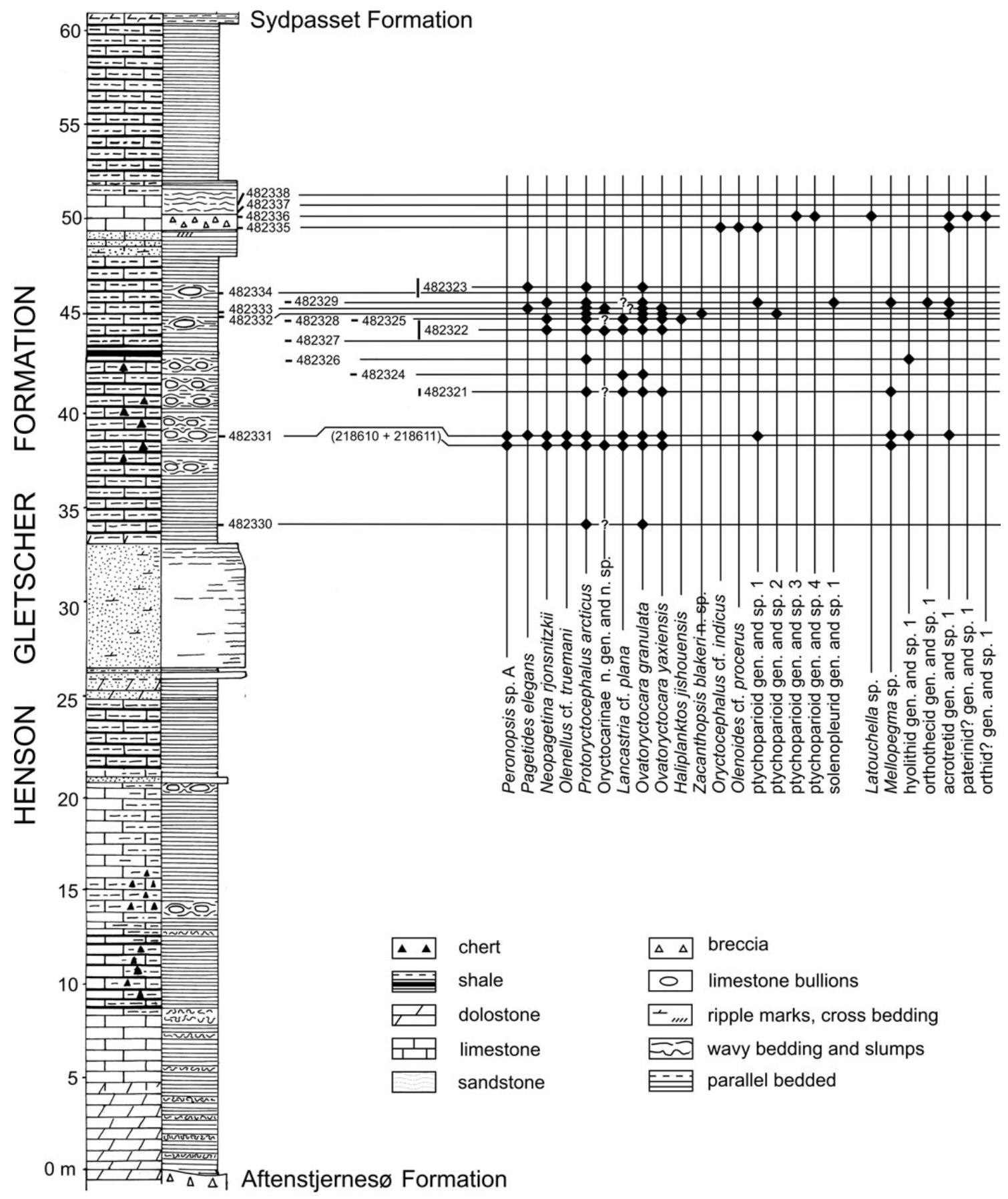

Figure 5. Lithologic profile showing distribution of GGU collections and trilobites (composite) within the Henson Gletscher Formation at localities 3 and 4 (Fig. 1D, E), Fimbuldal, Peary Land, North Greenland. Profile measured by Jon R. Ineson (1979).

Peronopsis (compare analysis of Peronopsis by Naimark 2008). Nonetheless, even if the anteroglabella of Eoagnostus roddyi is defined by clearly visible furrows, it is barely raised above the adjacent genae and distinctly, stepwise lower than the posteroglabella, a feature which separates it from ordinary species of Peronopsis (Fig. 11A-C, F, J).

Pagetides elegans Rasetti, 1945 (Fig. 12) was first described from the Lower Cambrian Ville Guay Conglomer- ate (= Sillery Formation) of Québec, Canada. The type material occurs as pyritized specimens in allochthonous bedded limestones in a dysoxic muddy slope facies at Ville Guay derived from the shelf margin. Autochthonous material of $P$. elegans is known from dark shales of the early part of the Hatch Hill dysaerobic interval of the slope facies at Anse Miranda (Landing et al. 2002), as well as the terminal Early Cambrian eustatic onlap that followed the Hawke 


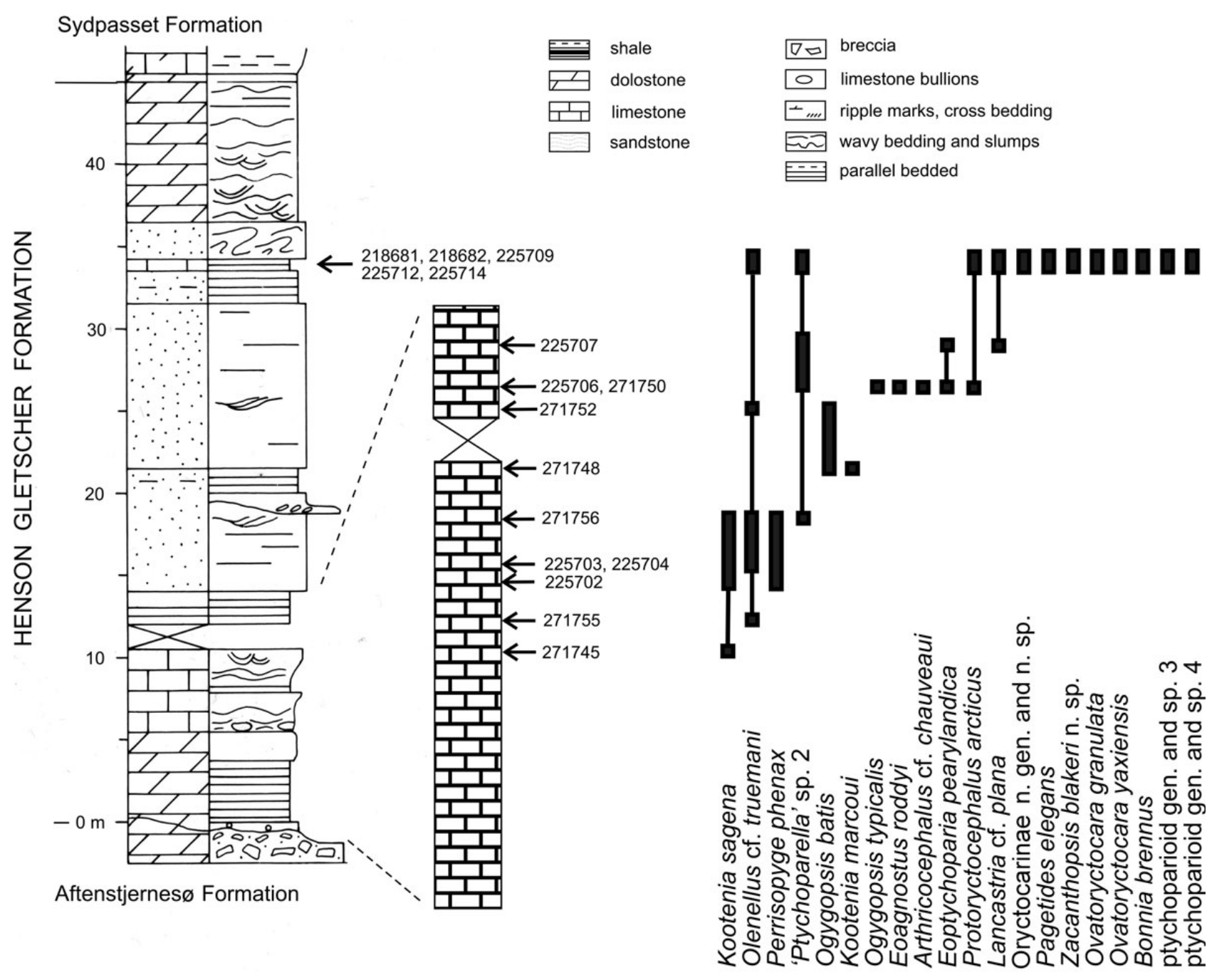

Figure 6. Lithologic profile showing distribution of GGU collections and trilobites within the Henson Gletscher Formation at locality 6 (Fig. 1D), Løndal, Peary Land, North Greenland. Profile measured by Jon R. Ineson (1979).

Bay regressive interval. The species occurs abundantly in the North Greenland sections, first together with the latest Olenellus specimens and then ranging up section beyond their highest occurrences.

The Pagetides elegans fauna of eastern Laurentia (Pagetides elegans and closely related miomerid species) occurs well below the LAD of the olenellid trilobites and below the extinction of Bathynotus in Laurentia. In contrast to supporting a simple correlation between Québec, Peary Land, and Avalonian Newfoundland using P. elegans, correlation using the Ovatoryctocara granulata faunas leads to the surprising conclusion that $P$. elegans has a considerable temporal range. In any case, the occurrence of $O$. granulata in the uppermost Brigus Formation of southeastern Newfoundland is older than that in the lower Kaili Formation of Guizhou, South China, as already addressed by Fletcher (2007).

Neopagetina rjonsnitzkii (Lermontova, 1940) (Fig. 13) is a traditional Siberian species first described from "the boundary Lower-Middle Cambrian" of the Peleduy River. Additional specimens were found in the Lena River region so that occurrences are recorded from the northern and the southern parts of the Siberian Platform. The Siberian material comes from the B. robustus-J. quadriceps Zone of the Botoman (Lazarenko \& Demokidov 1964, Ogienko \& Garina 2001). The only recognized occurrence of Neopagetina rjonsnitzkii outside Siberia is in the Henson Gletscher Formation of the Fimbuldal section (Fig. 5). The original single sample described by Blaker \& Peel (1997) has now been supplemented by five additional samples, all from more-or-less the same stratigraphic horizon, a short distance above the sandstone member.

A trilobite determined as Neopagetina aff. rjonsnitzkii was recovered from the highly important Leny Limestone of Scotland (Fletcher \& Rushton 2007), the faunas of which generally are woefully poorly preserved. Nevertheless, even these poorly preserved trilobites indicate a level 

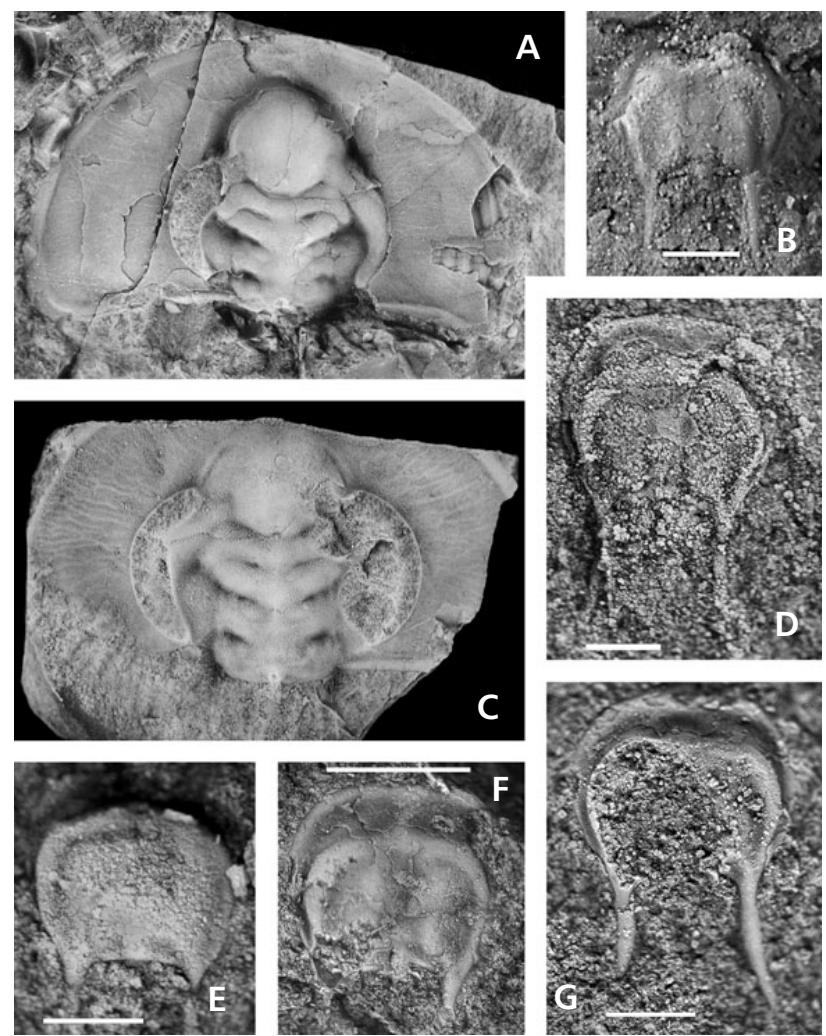

Figure 7. Olenellus cf. truemani Walcott, 1913, Henson Gletscher Formation. • A - incomplete cephalon, partly exfoliated, MGUH 23261 from GGU collection 301336, × 1.5. • B - meraspid, MGUH 29294 from GGU collection 482331, scale bar $0.5 \mathrm{~mm}$. C - partial cephalon, MGUH 23257 from GGU collection 271755, × 1.7. • D - meraspid, MGUH 29295 from GGU collection 482331, scale bar $1 \mathrm{~mm}$. $・ \mathrm{E}$ - protaspid, MGUH 29296 from GGU collection 482331, scale bar $0.5 \mathrm{~mm}$. $\bullet \mathrm{F}$ - meraspid, MGUH 29297 from GGU collection 218611, scale bar $1 \mathrm{~mm}$. $・ \mathrm{G}-$ meraspid, MGUH 29298 from GGU collection 218610, scale bar $1 \mathrm{~mm}$.

with a similar fauna to that with Neopagetina rjonsnitzkii in the Henson Gletscher Formation.

Zacanthopsis levis (Walcott, 1886), the type species of Zacanthopsis Resser, 1938, was originally described from the Lower Cambrian Pioche Shale near Pioche, Nevada. It was identified only from the latest Dyeran Combined Metals Member with certainty, where it more or less co-occurs with Bathynotus (originally identified as B. holopygus (Hall, 1859) and revised to B. granulatus Lermontova, 1940 or regarded as undeterminable by Webster 2009), various species of olenellids, Crassifimbra walcotti (Resser, 1937), Crassifimbra? metalaspis (Sundberg \& McCollum, 2000), and Oryctocephalites palmeri Sundberg \& McCollum, 1997. In the Freuchen Land section Zacanthopsis blakeri sp. nov., a species very similar to Z. levis, occurs in several samples both below and above the sandstone member (Fig. 8A-E), well into the range of Pagetides elegans (Fig. 4). Zacanthopsis contracta Palmer, 1964 was first described from the Lower Cambrian Saline Valley Formation of the Esmeralda County,
Nevada. Specimens tentatively assigned to this species were found in three samples from the Freuchen Land section representing a probably short interval below the sandstone member (Figs 4, 8F).

Stephenaspis? avita Palmer, 1964 is a remarkable record within the Henson Gletscher Formation fauna made by Blaker \& Peel (1997; see Fig. 8G); it was also first described from the Saline Valley Formation of Esmeralda County, Nevada. Palmer's original assignment remained tentative because the description was based on cranidia only. Nevertheless, Palmer (1964) discussed the possible presence of a pygidium which he described as "genus and species undetermined 4". This would place the species into close proximity with Poliella denticulata Rasetti, 1951 at the same time as lending it and its accompanying species an aspect of the upper Plagiura-Poliella faunas in the traditional sense (see Sundberg \& McCollum 2003 and McCollum \& Sundberg 2007 for biostratigraphic details). With regard to the Greenland record, Blaker \& Peel (1997) already noted that a possible associated pygidium, which they described as "corynexochid genus and species undetermined A", was found in the same sample from the Freuchen Land section as the Stephenaspis? avita cranidia, below the sandstone member (Blaker \& Peel 1997, fig. 61.1). In fact, another pygidium with a stronger Poliella-type aspect was found in an additional sample from the same faunal horizon.

Arthricocephalus chauveaui Bergeron, 1899 is one of the candidate species for the index fossil defining a GSSP at the base of the Cambrian Series 3 and Stage 5. It has been described as occurring in the Henson Gletscher Formation in three closely spaced sample horizons (GGU collections 315095, 315096 and 315099) in the Freuchen Land section (Blaker \& Peel 1997, fig. 10; see Fig. 4 herein) and in a single sample (GGU collection 225706) from the Løndal section (Blaker \& Peel 1997, fig. 11; see Fig. 6 herein). All of these samples are from below the sandstone member of the formation.

Eoagnostus roddyi and Protoryctocephalus arcticus are not present in these samples, but bracket the sample horizons so that Arthricocephalus appears to occur unusually late in the Peary Land sections. Re-examination of the Greenland material indicates some differences when compared to the specimens from South China, although these may be related to its mostly immature nature. In any case, the Greenland specimens cannot be attributed to A. chauveaui with certainty and are best treated as A. cf. chauveaui (Fig. 14). These specimens are accompanied by Haliplanktos jishouensis and Lancastria cf. plana.

Haliplanktos jishouensis (Zhou, 1977) was originally described as Arthricocephalus (Arthricocephalites) jishouensis Zhou, 1977 (in Zhou et al. 1977) from Hunan Province, South China, and selected as the type species of the (at that time) monotypic genus Haliplanktos by Blaker 

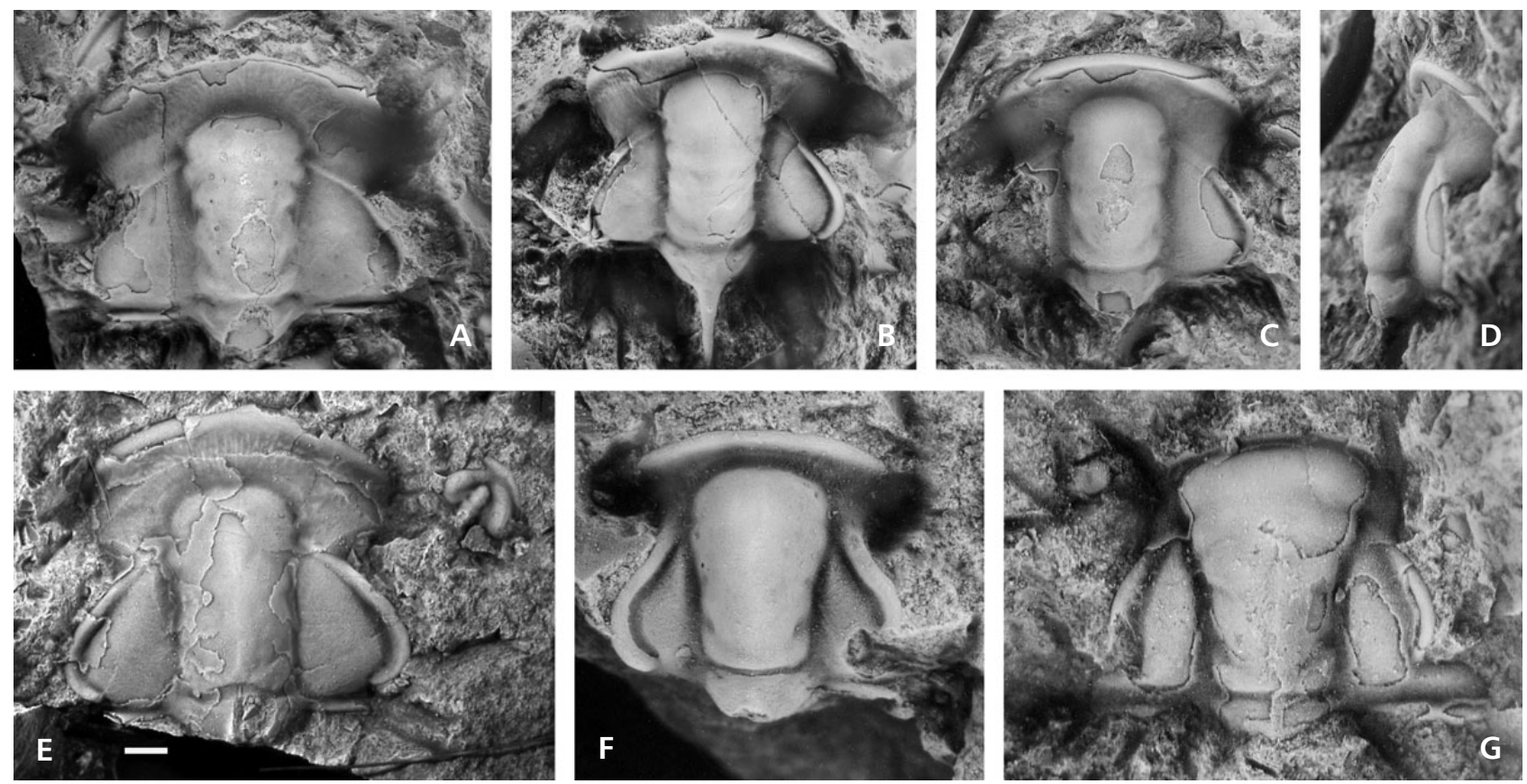

Figure 8. Henson Gletscher Formation trilobites. • A-E - Zacanthopsis blakeri sp. nov. (Walcott, 1886). A - paratype, incomplete cranidium, MGUH 23453 from GGU collection 301346, × 3.5. B - holotype, cranidium, MGUH 23457 from GGU collection 301346, × 4. C, D - paratype, incomplete cranidium, MGUH 23454 from GGU collection 301346, × 3.7. E - paratype, incomplete cranidium, largely exfoliated, MGUH 29299 from GGU collection 301348, $\times 5.5 /$ scale bar $1 \mathrm{~mm}$. $\bullet \mathrm{F}-$ Zacanthopsis cf. contracta Palmer, 1964, incomplete cranidium, MGUH 23462 from GGU collection 301343 , $\times 12 . \bullet \mathrm{G}-$ Stephenaspis? avita Palmer, 1964, incomplete cranidium, MGUH 23468 from GGU collection 301340, × 11 .

\& Peel (1997). The species record from the Henson Gletscher Formation in Freuchen Land (Figs 4, 15) was only the second record of a species otherwise known only with certainty from its type locality. Two additional species, H. pulchellus (Zhang \& Qian, 1980) (in Zhang et al. 1980, pl. 92, fig. 3) and H. taijiangensis (Yin, 1978) (in Yin et al. 1978, p. 441, pl. 156, fig. 8) are known from approximately the same stratigraphic level in South China. In particular, Haliplanktos taijiangensis is known from the upper part of the Balang Formation of the Guizhou province, where it co-occurs with Ovatoryctocara granulata (Zhao et al. 2001b, Yuan et al. 2009), but occurs in the Oryctocephalus indicus Zone in the Kaili Formation at other localities (Zhao et al. 2008). Yegorova et al. (1963, pl. 2, fig. 9) figured additional material from the Guizhou province as Arthricocephalus chauveaui, and these specimens also appear to represent $H$. jishouensis.

Haliplanktos jishouensis is present in the Henson Gletscher Formation from a single faunal horizon below the sandstone member (represented by three samples) where it co-occurs with Arthricocephalus cf. chauveaui.

Ovatoryctocara granulata Chernysheva, 1962 (Fig. 16), first described as Oryctocara (Ovatoryctocara) granulata from the Amgan of northern Siberia (Chernysheva 1962, pl. V, figs 6-8), is a second candidate as the index fossil for a GSSP characterizing the base of the Cambrian series 3 and stage 5. The species was first described from the
Kuonamka Formation of the middle part of the Olenek River in the Olenek Uplift, central North Siberian platform. Together with Ovatoryctocara ovata (Chernysheva, 1960), the type species of the widely distributed genus Ovatoryctocara, it characterizes the lowermost Middle Cambrian Oryctocara Zone of the Amga Stage within the open-marine Yudoma-Olenek facies belt of the northern and northeastern Siberian Platform; it therefore indicates the base of the Middle Cambrian on that Cambrian continent. This zone is now termed the Ovatoryctocara Zone, and the stage was renamed as the Molodoan (Rozanov et al. 2008) and the Molodian (Shabanov et al. 2008a), respectively. A detailed description of the best reference section at the Molodo River, southeastern slope of the Olenek Uplift, northeastern Siberian platform, was presented by Shabanov et al. (2008a). In that section, the range of $O$. granulata stretches over $c a 10 \mathrm{~m}$ of open marine carbonates from the base of the Ovatoryctocara Zone into the lower part of the Kounamkites Zone. Similar ranges are known from other sections in northeastern Siberia. Noteworthy is the co-occurrence of such trilobites as Pagetia ferox and P. horrida, Oryctocephalus vicinus, Eoptychoparia spp., Kounamkites spp., an undetermined Arthricocephalus species, and overlap with the range of Oryctocephalus reticulatus (e.g. Shabanov et al. 2008a).

According to several reports, Ovatoryctocara granulata occurs on the South China platform quite frequently 
in the lower part of the Kaili Formation of southeastern Guizhou, but only in a fairly limited part that is well above the base of the so-called Ovatoryctocara granulata-Bathynotus holopygus Zone of the Yangtze platform slope facies (Zhao et al. 2004, 2008; Yuan et al. 2009). However, recent investigations suggest that most of these specimens are better referred to as $O$. cf. granulata and that $O$. granulata may be limited to the lowermost portion of the Kaili Formation and the formation below (F. Sundberg, pers. comm. May 2011).

Ovatoryctocara yaxiensis Yuan, Zhao, Peng, Zhu \& Lin, 2009 was recently proposed for species of Ovatoryctocara from the Aoxi Formation of eastern Tongren, northeastern Guizhou. Yuan et al. (2009) argued that $O$. yaxiensis may have an earlier occurrence than $O$. granulata, possibly in the Arthricocephalus taijiangensis Zone. The supporting argumentation, however, is difficult to follow and appears to be inadequate to support such a conclusion. In addition, Yuan et al. (2009) described a valid new species but based on characters which appear to be insufficient to characterize the new taxon (see discussion under Genus Ovatoryctocara in the Systematic palaeontology section below). In fact, $O$. yaxiensis is strikingly separated from $O$. granulata by its wider and slightly shorter pygidial axis, the less pronounced boss posterior to the axis' terminal piece (not seen in all of the specimens), and the usually up to six (rather than seven) axial rings. The uncertainty in the original definition may result from the limited amount of material in the Aoxi Formation. The collections of $O$. yaxiensis from the Henson Gletscher Formation (Fig. 17) probably provide a more reliable base for the comprehension of the species.

The assemblages from North Greenland have the richest known occurrences of Ovatoryctocara on a global scale. About 300 specimens were examined during this study, occurring in at least 15 different samples from three different areas. They include fairly complete ontogenetic series and reflect different types of preservation. Thus, the suggestion that the Greenland specimens "may represent an indefinite species" (Yuan et al. 2009, p. 213) is certainly incorrect. The earlier collected specimens were all described as Ovatoryctocara sp. A (Blaker \& Peel 1997, p. 114 , figs 65,66$)$. In fact, they represent at least two distinct species, one falling perfectly within the morphological range of Ovatoryctocara granulata from the type region of Siberia, while the other is identified herein as the newly established $O$. yaxiensis from South China.

Interestingly, both species co-occur in the Henson Gletscher Formation in several samples, and distinct differences in their stratigraphic ranges do not appear to exist. In the type section of the Henson Gletscher Formation in Lauge Koch Land (Fig. 1D, locality 2), as well as in the re-collected Fimbuldal section (Fig. 5), both species occur above the sandstone member only, and in the restudied
Løndal material they occur in the intercalated limestone unit slightly below the top of the sandstone member. Only two specimens of Ovatoryctocara cf. granulata have been discovered in a single sample from Freuchen Land section, also above the sandstone member (Fig. 4).

Ovatoryctocara has been reported also from the Jigging Cove Member of the uppermost Brigus Formation (cited as "Branch Cove Marl Member") at Easter Cove, St. Mary's Bay, Avalonian southeastern Newfoundland (Fletcher 2003; see Landing 1992 and Landing \& Westrop 1996, for West Avalonian stratigraphic nomenclature). The very few recovered specimens from the so-called upper Cephalopyge Zone were assigned to O. granulata. Yuan et al. (2009, pp. 213, 217) argued that the specimens are "more similar to $O$. yaxiensis sp. nov. [...] because of lack of longitudinal furrows on glabella, and [...] shorter palpebral lobes, much wider posterolateral area (exsag.), and rather elevated relief of cranidium and pygidium" and "cannot be identified to species level". These characters can be explained by a less strong deformation than that seen in specimens from the Kaili Formation. Stronger flattening creates deeper longitudinal grooves on the glabella and, of course, explains the lesser convexity on the Guizhou specimens compared with those from Newfoundland. Although tectonic deformation has most likely occurred in southeastern Newfoundland, the few Avalonian specimens from St. Mary's Bay are quite well preserved due to their preservation in calcareous concretions (Fletcher 1972, 1999, 2003). They suffer, however, from their incompleteness and their sparse number (only one cranidium and two pygidia known). Their morphology, however, compares very well with that of the Siberian specimens of $O$. granulata so that they are assigned to this species with high confidence. Unfortunately, all specimens were collected from a single horizon at the very top of the Jigging Cove Member of the Brigus Formation so that the true range of the species cannot be determined. Even the original horizon in this section with its calcareous nodules appears to have been fully exploited now.

Interestingly, pygidia with the morphologic characters of Ovatoryctocara yaxiensis are also present within the Siberian material and again occur in the same strata as O. granulata. One example is a pygidium figured by Shabanov et al. (2008a, pl. 8, fig. 9).

Ogygopsis cf. batis (Walcott, 1916) is present in several samples of the Henson Gletscher Formation from Freuchen Land, all from below the sandstone member (Figs 4, 9A, B). The specimens from Freuchen Land differ from the type material from the Olenellus Zone of Miller Mountain in Nevada and redescribed by Palmer (1964), in having a slightly stronger inflated glabella, lack an indentation of the posterior pygidial border and the spine on the anterior lateral corners of the pygidium (see Palmer 1964). Ogygopsis batis may be interpreted as identical with 
O. sibirica (E.E. Romanenko, 1960) (in Khalfin 1960), described from the upper Toyonian of the Suyarik River area of the High Altay Mountains (Chernysheva 1971, Yegorova et al. 1976), which would imply considerable morphological variability. In addition, Ogygopsis batis has also been identified from the upper Toyonian Anabaraspis splendens Zone of the Elanka (= Elanskoe) Formation in the Elanka section of the Lena region (Yegorova et al. 1976).

Ogygopsis virgata (E.E. Romanenko, 1962) was discovered in large numbers in three samples (GGU collections 298544, 301343, 315097) collected from the Freuchen Land section, all representing a single horizon known from a spot sample just below Arthricocephalus cf. chauveaui in the Freuchen Land section (Figs 2, 4, 9C-H). The type material was described as Kootenia virgata from the lowermost Middle Cambrian Suyarik "horizon" of the High Altay Mountains (Romanenko in Romanenko \& Romanenko 1962) and redescribed by Chernysheva (1971). The species is a close relative of Ogygopsis antiqua Palmer, 1968 from the Hillard Limestone of Alaska; Blaker (1986) and Blaker \& Peel (1997) even synoymised these species.

Ogygopsis typicalis (Resser, 1939) was originally described as Taxioura typicalis from the so-called "Ptarmigania strata" or "Ptarmigania fauna" in the Naomi Peak Member of the basal Langston Formation of northeastern Utah and southeastern Idaho (Maxey 1958), where it is probably associated with faunas of of the early Middle Cambrian Mexicella mexicana (= traditional Albertella Zone). The species has also been described from the Carrara Formation in the Belted Range, Nevada (Palmer \& Halley 1979). In North Greenland, specimens with $O$. typicalis morphology have been found in samples from the Løndal section (Fig. 6) below the sandstone member as well as in a sample from Freuchen Land where in contrast it occurs above the sandstone member (Figs 4, 9I-M). The type specimens of $O$. typicalis show a prominent indentation at the anterior end of the pygidium, which is is absent in the specimens of the specimens from North Greenland, as well in those illustrated by Palmer \& Halley (1979).

Olenoides occurs in one sample (GGU collection 482335) from the Fimbuldal section (Figs 5, 9N) from the mass flow carbonate breccia horizon in the upper part of the section. This single Olenoides specimen is indistinguishable from Olenoides procerus Tomashpolskaya, 1971 (in Chernysheva 1971, pl. 13, figs 4-6), known only from the lower Amgan Suyarik "horizon" of the Sukhoy Erby River area in the Batenev Ridge of the Sayan-Altay Foldbelt. A similar species was described as Olenoides foveolatus Rasetti, 1948 from allochthonous boulders of the conglomerates of the Lévis Formation, Québec (Rasetti 1948b).

Protoryctocephalus arcticus sp. nov. is a very frequent species in almost all of the sections (Figs 4-6, 18). It has a slightly club-shaped Oryctocephalus-type glabella and a distinct anterior border. The pygidium is minute and framed by the backwardly-directed spines of the posterior thoracic pleurae.

Protoryctocephalus arcticus was originally described from the Henson Gletscher Formation by Blaker \& Peel (1997) as Oryctocephalus vicinus Chernysheva, 1962, another species from the relative deep water facies of the eastern Siberian platform. That species also occurs in the Kuonamka Formation, with an FAD slightly above the base of the Ovatoryctocara Zone and ranges to the top of the Kounamkites Zone (Shabanov et al. 2008a). The differences in the cranidial morphology between Protoryctocephalus arcticus and the Siberian O. vicinus are minor and focus on a slightly wider glabella, slightly longer palpebral lobes (often reaching almost to the posterior border furrow) and slightly more laterally projecting posterior projections of the fixigenae.

Remarkably, no pygidia assigned to Oryctocephalus vicinus were illustrated from the Molodo section. A specimen identified as the pygidium of Ovatoryctocara granulata from horizon 9 (Shabanov et al. 2008a, pl. 10, fig. 9) obviously shows a posterior part of a thorax with an attached pygidium which does not belong in $O$. granulata. This specimen is most similar to those of P. arcticus in the Henson Gletscher Formation so that it cannot be excluded that the Molodo material belongs to the same or a closely related species.

Protoryctocephalus arcticus is similar in most character to $P$. wuxunensis Chow, 1974 (in Lu et al., 1974) and P. balangensis Zhao \& Yuan, 2002 (in Yuan et al., 2002), known from the Wuxun Formation and the lowermost part of the Kaili Formation of southeastern Guizhou, respectively, suggesting a coeval stratigraphical position. In particular, the distinct morphology of the minute pygidium suggests at least a common ancestry. Distinct differences can be seen in the relatively broader (tr.) fixigenae and the less strongly backwardly directed eye-ridges of the species from the Henson Gletscher Formation. In addition, Yuan J.L. (pers. comm. to GG, November 2010) suggests that $P$. arcticus has now been found in the Balang Formation of Guizhou.

Protoryctocephalus arcticus has an unusually long distribution and ranges from the lower Henson Gletscher Formation (below the sandstone member) into the horizons with Pagetides elegans; it is present in the three sections illustrated herein (Figs 4-6) and in the type section in Lauge Koch Land (Blaker \& Peel 1997, fig. 9). It is most frequent in the upper part of its range and within those samples with abundant occurrences of Ovatoryctocara (Fig. 5). This is certainly a matter of facial control, and the species obviously favoured habitats with a muddy substrate.

Oryctocephalus indicus is the trilobite species which is frequently regarded as the best possible indicator for the global Cambrian Series 2-Series 3 boundary. It has not been detected in the Henson Gletscher Formation with 
certainty. Nevertheless, a single well-preserved cranidium is known from the matrix of the mass flow limestone breccia horizon of the Fimbuldal section (Figs 5, 19A) which is indistinguishable from the well preserved specimens identified as Oryctocephalus indicus from the Kaili Formation of Guizhou (e.g. Yuan et al. 2003).

Lancastria Kobayashi, 1935 (Figs 19, 20) was reported by Blaker \& Peel (1997) on the basis of material described as Lancastria plana (Tomashpolskaya, 1960). This species was originally described as Paraoryctocephalops plana Tomashpolskaya, 1960 (in Khalfin 1960) from the Blagodatskaya Svita of the Dolgiy Mys range in the Batenev Ridge of the Sayan-Altay Foldbelt, where it occurs together with Kooteniella slatkowski, Edelsteinaspis ornata, Dinesus sibiricus, Paraoryctocephalops sibirica, and others, indicating a position in the Obruchev "Horizon" of the Sayan-Altay standard zonation (= upper Toyonian in the Siberian Platform standard). The assignment is based solely on the cranidium, which has a glabella slightly expanding forward and with a relatively straight anterior margin of the frontal lobe. This frontal lobe usually bears a clear median indention that is not present in Lancastria roddyi (Walcott, 1912), the type species of the genus from the Kinzers Formation at Lancaster, Pennsylvania. The anterior margin of the cranidium is simply upturned, but there is a low and usually poorly defined ridge on the preocular areas (Fig. 20). The morphology of the cranidium of the Greenland material does indeed match that of the Sayan-Altay Foldbelt, with only the palpebral lobes being slightly shorter than those in the usual Greenland specimens, and the glabella apparently slightly more expanding forward. Unfortunately, only the cranidium is known from the Batenev Ridge so that the material from the Henson Gletscher Formation is dealt with here as Lancastria cf. plana. The pygidium of the Greenland specimens is small, consisting of only one axial ring plus a terminal axial piece, and is further characterized by long rearward directed spines. The pygidium resembles the pygidium seen in the holotype of Lancastria roddyi.

Lancastria plana occurs in its type area together with Arthricocephalus chauveaui, and the "Siberian" genus Dinesus has now been found in the coeval strata of South
China (Yuan J.L., pers. comm. to GG, November 2010). In North Greenland the range of Lancastria cf. plana extends into the level with Ovatoryctocara granulata. Its occurrence both below and above the medial sandstone member in the Henson Gletscher faunas strongly suggests that the chronometric difference between these levels is less dramatic than has been previously supposed.

A similar species was described as Goldfieldia kunshanensis Zhang \& Zhou, 1985 from the southern Jiangsu Province of South China, where it occurs above the species of Arthricocephalus (Zhang \& Zhou 1985), but is associated with "Changaspis taihuensis", which represents another species of Goldfieldia.

Ptychoparioid species with a "primordial" character set were grouped under Ptychoparella sp. A by Blaker \& Peel (1997) notwithstanding considerable morphological differences to existing species of Ptychoparella. Despite an astounding variability, diagnostic features can be observed that require placement of these specimens even under different genera (compare Blaker \& Peel 1998, figs 73-79). The plethora of these ptychoparioid species present in the lower part of the Henson Gletscher Formation would have been assigned to the family Antagmidae Hupé, 1953. However, as shown by Sundberg (2007), the nominal genus Antagmus Resser, 1936 is based on a specimen too poorly preserved for precise recognition (see Sundberg 2007, fig. 9b) so that the genus is a nomen dubium and the name Antagmidae is to be regarded as invalid. As most of this clade and closely related families are in urgent need of a comprehensive revision, there is no simple and satisfying taxonomic solution to this problem. None of these forms can be assigned to any existing species although numerous closely related species and forms have been reported, mostly from the Great Basin area. One example is the species represented by the specimens figured by Blaker \& Peel (1997, fig. 73) as Ptychoparella sp. A, all of which come from the limestone intercalation just below the top of the sandstone member in the Løndal section (Fig. 6). This species appears to occur in the Albertella Zone of the Carrara Formation of the Nevada Test Site and was figured by Palmer \& Halley (1979, pl. 15, fig. 6) as "ptychopariid undet. 6". Another form is very similar to

Figure 9. Henson Gletscher Formation trilobites. - A, B - Ogygopsis cf. batis (Walcott, 1916). A - almost complete immature carapace with disarticulated librigenae, latex cast of external mould, MGUH 23291 from GGU collection 315093, × 6.5. B - holaspid carapace without librigenae, partly exfoliated, MGUH 23300 from GGU collection 301336, × 3.6. • C-H - Ogygopsis virgata (E.E. Romanenko, 1962). C - pygidium, MGUH 23342 from GGU collection 315097, × 6. D - pygidium, MGUH 23338 from GGU collection 298544, × 6. E - meraspid cranidium, MGUH 23322 from GGU collection 325097, × 18. F - cranidium, MGUH 23327 from GGU collection 298544, × 8.2; note prosopon of polygonal meshwork of subconcentrically arranged ridges on glabella and (less clearly) on fixigenae and terrace ridges on anterior border. G - cranidium, MGUH 23325 from GGU collection 298544, × 6; note prosopon of polygonal meshwork. H - immature pygidium, MGUH 23341 from GGU collection 298544 , $\times 10$. $\bullet$ I-M - Ogygopsis typicalis (Resser, 1939). I - incomplete cranidium, MGUH 23308 from GGU collection 271750, $\times 2.8$. J - librigena, latex cast of external mould, MGUH 23309 from GGU collection $271750, \times 4.6$. K - pygidium, largely exfoliated and with partly exposed doublure of lateral border, MGUH 23317 from GGU collection 301342, × 3.1. L - pygidium, MGUH 23316 from GGU collection 301342, × 2.4. M - hypostome, MGUH 23311 from GGU collection $271750, \times 5.3 \cdot \cdot \mathrm{N}-$ Olenoides $\mathrm{cf}$. procerus Tomashpolskaya, 1971, incomplete cranidium, MGUH 29300 from GGU collection $482335, \times 7.8$. 

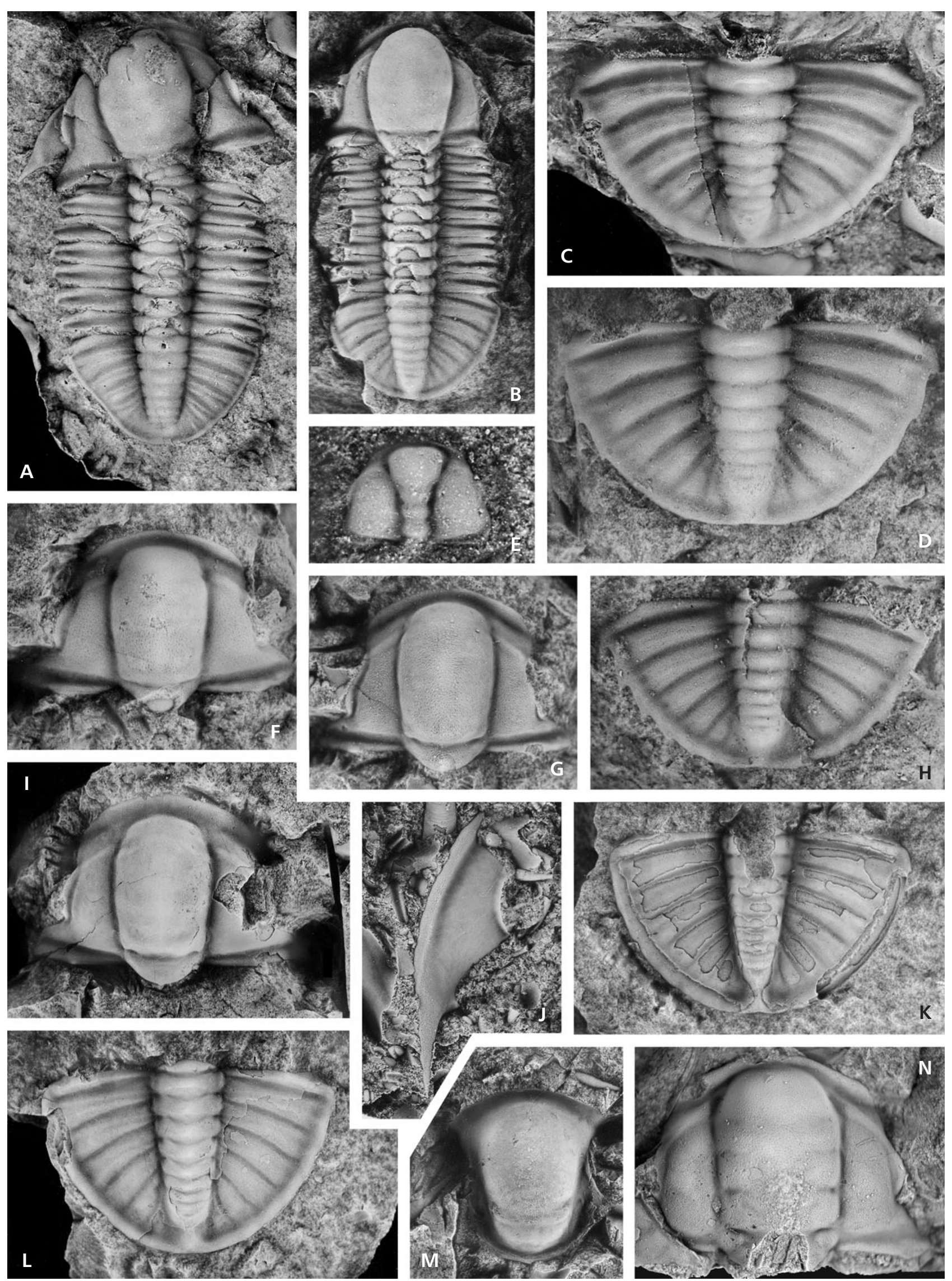
specimens described as "Xiaofangshangia? sp." by Yuan et al. (2009, fig. 4h, j-m) from the Aoxi Formation of Tongren, Guizhou, co-occurring with Ovatoryctocara yaxiensis.

Two of the species are formally described in the systematic section as Eoptychoparia pearylandica sp. nov. (Fig. 21) and Onchocephalus? freucheni sp. nov. (Fig. 22).

\section{Implications for global correlation}

Correlation based on trilobites in the vicinity of the Cambrian Series 2-Series 3 boundary is beset by substantial problems mainly because of (1) pronounced faunal provincialism across the traditional Lower-Middle Cambrian boundary interval; (2) the limited occurrence of fossil bearing strata in this interval in most of the regions in which the boundary was chosen; and (3) the mostly paucispecific fossil assemblages. (2) and (3) are the result of multiple eustatic and epeirogenic sea-level fluctuations generally (and unsuitably) summarized as the "Hawke Bay Event" (Palmer \& James 1980), suggesting that a refined sequence stratigraphic analysis of the critical sections offers potential for improved correlation, such as between West Gondwana, Avalonia, and Baltica. Some Cambrian continents, however, appear to have an epeirogenic history too complex to be tied with others without robust biostratigraphic data (Landing et al. 2006).

Other non-traditional stratigraphic methods (such as carbon isotope stratigraphy or magnetostratigraphy) have been studied only recently in more detail and are not available for most regions with an important Lower-Middle Cambrian interval, or can be shown to lack the necessary potential for precision at this stratigraphic interval. Clearly, a satisfactory GSSP will need to be based on paleontological data. Carbon isotopes may be useful for delimiting the Ediacaran-Cambrian boundary interval and the earliest Cambrian period for which several positive carbon isotope excursions can be detected in various regions (Banerjee et al. 1994; Brasier 1985, 1991, 1992, 1994; Brasier et al. 1990, 1992, 1993, 1994a, 1994b; Brasier \& Sukhov 1998; Derry et al. 1994). Nevertheless, such distinct excursions are largely absent (or not yet recognized) for the second half of the Early Cambrian and the early Middle Cambrian, although several regional studies seem to promise useful results (e.g. Montañez et al. 2002, Yang et al. 2003, Guo et al. 2005). Moreover, during the process of introducing carbon isotopes as a distinct stratigraphic tool, it has become clear that calibration with other timecalibrated scales is needed to permit reliable intercontinental correlation; later geochronological and/or biostratigraphical data have proved that "early" applications of these techniques were misleading or even erroneous (e.g. Kirschvink et al. 1991, Magaritz et al. 1991).
Recent discussions of the utility of trilobites as the major correlation tool for recognition of the boundary between Cambrian series 2 and 3 (and stages 4 and 5) focus on the levels of the FAD of Oryctocephalus indicus and Ovatoryctocara granulata, respectively; the previously suggested possibility to utilize Arthricocephalus chauveaui as the index fossil for global correlation is no longer favoured. All three species have been investigated recently by the Lower-Middle Cambrian working group of the ICS Cambrian Subcommission. A first vote of the Subcommission's Voting Members demonstrated a slight preference for the Oryctocephalus indicus level for a potential GSSP (Sundberg 2009). Both stratigraphic levels can be correlated between certain Cambrian continents. Nevertheless, direct correlation is not possible between all critical areas so that it is necessary to scrutinize which of the two favoured horizons provides the greatest utility as a future GSSP level.

\section{Arthricocephalus chauveaui}

Arthricocephalus chauveaui Bergeron, 1899 was first described from the present-day Balang Formation of northeastern Guizhou. It was subsequently found in other parts of the Yangtze (or South China) Platform, in Avalonian Newfoundland (Fletcher 2001, 2003), Siberia (see below) and in North Greenland (Blaker \& Peel 1997, see Fig. 14), although this record is now regarded as tentative.

This species was earlier regarded as showing considerable promise for a relatively precise intercontinental, or even global, correlation and came into focus as a possible GSSP level in the course of the widespread research on the Kaili Formation and its faunas (e.g. Yuan et al. 2006). Its identity has been a matter for debate, and its FAD is in a stratigraphic position that lies well within traditional Lower Cambrian strata in most regions. In addition, the utility of Arthricocephalus chauveaui as a prime index fossil has been questioned due to the notable effects of deformation on its morphological, and hence systematic, delimitation.

Subsequent to the first description of Arthricocephalus chauveaui, additional studies in Guizhou and neighbouring Chinese provinces on the South China/Yangtze platform heralded the introduction of another 9 species and up to three subgenera of this genus, partly raised to generic level or synonymised subsequently (see Zhang et al. 1980, and Yuan et al. 2002, for an overview). Particularly in South China, small differences in morphological details led to the introduction of numerous different species attributed to Arthricocephalus and Arthricocephalites. Several studies of Athricocephalus chauveaui demonstrate the problems in identification that may arise if specimens are affected by compression or tectonic deformation, whilst even the ontogenetic variability may become problematic (Blaker \& 
Peel 1997, Fletcher 2001, McNamara et al. 2003). Despite these studies, it remains unresolved as to what extent the taxonomic distinction has hypertrophied. Blaker \& Peel (1997) and McNamara et al. (2003) synonymised and reduced Arthricocephalus to four species, with Arthricocephalus duyunensis Chien, 1961, A. horridus Qian \& Lin, 1980, and A. granulus Chien \& Lin, 1977 being synonymised with A. chauveaui. In addition, Arthricocephalites was recognized as being based on characters present in early stages of the ontogeny of Arthricocephalus in a way that makes them unsuitable for defining a subgenus or even higher taxon. Specimens of other species were erroneously determined as Arthricocephalus chauveaui by Yegorova et al. (1963) and Lu et al. (1965).

Nevertheless, it is unclear for reasons of preservation, if other species (see Zhang et al. 1980 for a fairly complete list) are well defined. In particular, an analysis of the ontogeny of A. chauveaui from the Balang Formation of Guizhou (McNamara et al. 2003) illustrates the morphologic plasticity of the species but also proves that certain character states seen in figured material obviously are not characteristic for this species. As a result, no general agreement appears to exist as to whether or not Oryctocarella sibirica Tomashpolskaya \& Karpinskiy, 1962 from the Yerby area of the Batenev Ridge in the Sayan-Altay Foldbelt is a junior synonym of Arthricocephalus chauveaui, and if specimens from Siberia described as Oryctocara sibirica (e.g. Tomashpolskaya in Khalfin 1960, pl. 33, fig. 5) or Ovatoryctocara (Chernysheva 1971, pl. 13, figs 8,9) in fact belong to Arthricocephalus chauveaui.

The type material from the Balang Formation of northeastern Guizhou and subsequently discovered material of A. chauveaui in other locations in the slope facies of South China Platform led to the assignment of the species as an index fossil for the Arthricocephalus chauveaui Zone at the base of the Duyunian. This zone is overlain by the Arthricocephalites taijiangensis Zone, whereas the Ovatoryctocara granulata-Bathynotus holopygus Zone, some two zones above, forms the top of the Duyunian. The A. chauveaui Zone corresponds to the traditional Megapalaeolenus Zone of the topmost Canglangpuan in the platform facies of the South China platform (e.g. Yuan et al. 2009). Thus, A. chauveaui occurs just below the traditional stratigraphic interval with the latest and most significant species of Redlichia s. str. [e.g. Redlichia (Pteroredlichia) guizhouensis], known as the Longwangmiaoan (see Zhao et al. 2001, Yuan et al. 2009), which marks the top of the traditional Lower Cambrian in China. As mentioned above, Ovatoryctocara occurs above this level. Fletcher (2003) has already noted that the overlying lowermost Middle Cambrian Xystridura-bearing strata at Yaxian, Hainan Province, yield specimens of Kiskinella luoyacunnensis (Lin \& Jago, 1993), a species which is at least a very close relative of $K$. cristata.
The material from the Henson Gletscher Formation shows slight differences to the morphologic range exhibited by the Guizhou material. These specimens (Blaker \& Peel 1997, figs 63, 64.1-64.4), assigned now to Arthricocephalus cf. chauveaui, were found in samples with Haliplanktos jishouensis and Lancastria cf. plana and bracketed by occurrences of Eoagnostus roddyi. Ogygopsis typicalis is another characteristic trilobite species of this association. Thus, it appears that that the stratigraphic ranges of Ovatoryctocara granulata and the newly discovered $O$. yaxiensis start at a slightly younger level. Haliplanktos jishouensis also occurs with A. chauveaui in South China, and specimens of this species were erroneously determined as Arthricocephalus chauveaui by Yegorova et al. (1963) and Lu et al. (1965).

Lancastria cf. plana is morphologically very close to Lancastria plana (Tomashpolskaya, 1960), but cannot be identified unequivocally because of the imperfect knowledge of this species in its type locality in the High Altay Mountains where it occurs together with Arthricocephalus chauveaui. In North Greenland, the range of Lancastria cf. plana extends well into the strata with Ovatoryctocara granulata. In this context, the sections of North Greenland suggest that the chronometric difference between the Arthricocephalus cf. chauveaui and the Ovatoryctocara granulata levels is less dramatic than previously assumed. Pagetides elegans, by contrast, first occurs slightly above A. cf. chauveaui in the Henson Gletscher Formation.

In summary, four alternatives present themselves:

(i) There is a discrepancy in the stratigraphic ranges of A. chauveaui and $O$. granulata in different Cambrian continents which strongly affects their value as index fossils.

(ii) The elaborate zonation in South China and particularly Guizhou reflects a local high rate of sedimentation together with a sophisticated regional biofacies framework.

(iii) Sections outside South China suffer from the presence of cryptic unconformities immediately above the A. chauveaui level.

(iv) The quite strong differences in the stratigraphic occurrences of A. chauveaui result, in part, from difficulties in identification.

Regardless of these problems, the difficulties associated with confident identification of Arthricocephalus chauveaui indicate that the true ranges of the species are probably not known with sufficient precision. A major disadvantage of the stratigraphic interval with $A$. chauveaui is that there are few additional species to confirm or extend intercontinental correlations.

\section{Ovatoryctocara granulata}

As summarized earlier (Yegorova \& Savitskiy 1976, Fletcher 2003, Geyer 2006), Ovatoryctocara granulata is 
a fairly common trilobite in the lower Amgan of the Yudoma-Olenek facies region where it defines the lowermost Amgan biozone and thus the base of the Middle Cambrian series. The original concept of Siberian stratigraphy placed the Elankan as the lower part of the Amgan s.1., but this was later transferred to the terminal Early Cambrian following a decision of the USSR All-Union Stratigraphic Workshop in 1983. Well preserved and instructive material of $O$. granulata is known from several areas in Siberia, such as the Nekekit River area (Savitskiy et al. 1972, Yegorova et al. 1976) where the eponymous Nekekit River section is now the stratotype for the open-marine Yudoma-Olenek facies belt of the northern and northeastern Siberian Platform. Additional well-preserved specimens have been recovered from the Molodo River area on the Olenek Uplift, and this section has provided the motivation to rename the stratigraphic interval the Molodian (Korovnikov 2001, Shabanov et al. 2008a).

As mentioned above, the most important source of Ovatoryctocara granulata on the South China continent was believed to be the lowermost Kaili Formation of Guizhou, where the species occurs in the Ovatoryctocara granulata-Bathynotus holopygus Zone of the Duyunian (Yuan et al. 1997, 2001, 2003). However, recent discussions indicate that a considerable part of the material may not represent O. granulata (e.g., Yuan et al. 2009; Sundberg \& S.C. Peng, written communication to the Lower-Middle Cambrian GSSP Working Group, September 25 and 26, 2010).

The assemblages from North Greenland preserve the richest occurrences of Ovatoryctocara on a global scale. They include fairly complete ontogenetic series and reflect different types of preservation. Earlier collected specimens were all described as Ovatoryctocara sp. A (Blaker \& Peel 1997, p. 114, figs 65, 66). In fact, they represent at least two distinct species, one falling perfectly within the morphological range of Ovatoryctocara granulata from the type region of Siberia, the other representing the newly established O. yaxiensis Yuan et al. 2009, first described from Guizhou, South China. Both species co-occur in the Henson Gletscher Formation in several samples, and distinct differences in the stratigraphic range do not appear to exist. In the type section of the Henson Gletscher Formation in Lauge Koch Land (Fig. 1D, E, locality 2), as well as in the re-collected Fimbuldal section (Fig. 1D, E, locality 3; Fig. 5), both species occur only above the sandstone member, although only scant palaeontological material is available from the type section. In the restudied Løndal section (Fig. 1D, E, locality 6; Fig. 6) they occur in the intercalated limestone unit slightly below the top of the sandstone member.

In addition to the North Greenland material, specimens of $O$. granulata have been found in the Avalonian of southeastern Newfoundland (Fletcher 2003). Furthermore,
Chernysheva (1971) described specimens identified as Oryctocara (Ovatoryctocara) sp. from the Eldakh "Horizon" of the lower Amgan of the Azyrtal mountain region in the Batenev Ridge of the Sayan Altay Fold-Belt. These specimens differ from Ovatoryctocara granulata in terms of the relatively coarsely grained ornamentation on the cranidium and a broader pygidium with only six axial rings.

A new species of Ovatoryctocara recently identified from the Mackenzie Mountains, northwestern Canada (Terfelt \& Butterfield 2010), resembles the Siberian species Ovatoryctocara doliiformis. Regardless of their specific identities, the limited occurrence of all species of Ovatoryctocara within the $O$. granulata Zone indicates that the appearance of this new species is the first more or less precise indication of the base of the Series 3 in the $\mathrm{Ca}$ nadian Cordillera.

Although this should not be a key point in the decision on a GSSP, the FAD of Ovatoryctocara granulata has the advantage of lying at a level which agrees quite well with traditional Lower-Middle Cambrian boundary concept in several regions, such as Avalonia and parts of West Gondwana. Thus, selecting this level for the GSSP would result in only minimal change in many areas between the lower boundary of Series 3 and the base of the traditional Middle Cambrian.

Small individuals of Ovatoryctocara granulata can be affected to some degree by tectonic distortion. Unfortunately, very many of the $O$. granulata specimens from Guizhou are slightly distorted so that the restricted stratigraphic range of the species (by comparison with that of Oryctocephalus indicus) may suffer from problems of correct determination. In addition, the material from southeastern Newfoundland is extremely sparse. Thus, critical arguments have been advanced (e.g. Yuan et al. 2009) concerning the true range of Ovatoryctocara and its possible limitation by facies changes. The Ovatoryctocara interval of the Henson Gletscher Formation yields, in part, fairly well-preserved specimens and can be correlated with other areas of the greater Laurentian continent if the Oryctocephalus indicus interval and additional species discussed herein are used to pinpoint the Ovatoryctocara interval. In addition, it provides the probably best expression of the acme with $O$. granulata and $O$. yaxiensis known to date. Well preserved material is known not only from Siberia and Greenland, but also from Newfoundland and South China, so that four continents can be tied together with some confidence. Moreover, co-occurring trilobites in the O. granulata range-zone are usable as auxiliary index-fossils that provide the possibility of reasonable correlation into other Cambrian continents such as West Gondwana, Baltica, and East Gondwana.

The occurrence of Pagetides elegans suggests a correlation with obviously coeval strata in the Humber 
Tectono-stratigraphical Zone, primarily in the allochthonous successions of the Taconic Appalachian Orogen in Québec and New York State. A main source of these faunas was limestone boulders within the Early Ordovician conglomerates of the Lévis Formation (Rasetti 1945) on the southern side of St. Lawrence River, between Lévis and Grosses Roches in the western part of the Gaspé Peninsula. Equivalent, albeit rather poorly preserved, trilobite faunas (with Pagetides amplifrons, Neopagetina aff. rjonsnitzkii, Kiskinella cristata, Bathydiscus cf. dolichometopus, Condylopyge cf. eli) of this stratigraphic interval are known from the Leny Limestone near Callender, Scotland (Fletcher \& Rushton 2007). It should be noted that this type of Pagetides elegans fauna occurs not only well below the extinction of olenellids but also appears to be at a stratigraphic level below the LAD of Bathynotus in Laurentia (Fletcher 2007).

Kiskinella cristata Romanenko \& Romanenko, 1962 is a key species for intercontinental correlation. Whilst originally described from the Amgan Suyarik "horizon" in the Kiska River area of the High Altay Mountains, this species was subsequently discovered in the Mundybash "horizon" of the Dolgiy Mys range, Batenev Ridge (Chernysheva 1971), in the Braintree Member ("Easter Cove Manganiferous Member") of the Chamberlain's Brook Formation of Cape St. Mary's Peninsula, southeastern Newfoundland (Fletcher 2003), and in the Leny Limestone of Scotland (Fletcher \& Rushton 2007). Especially the well preserved specimens found with and immediately above the $O$. granulata level in the Easter Cove section permit confident determination. Unlike Ovatoryctocara granulata, Kiskinella cristata is known from a number of samples in the lower Chamberlain's Brook Formation, but it remains uncertain whether or not these occurrences depict its true stratigraphic range. A similar species, Kiskinella decora Yegorova, 1967, occurs in the lower Amgan Kounamkites Zone of the Daldyn River Basin in the northern Prianabar region on the Siberian Platform (Yegorova \& Savitskiy 1969).

As already addressed by Fletcher (2003), an at least very similar species has been described as Pagetia luoyacunensis Lin \& Jago, 1993 from the Hainan Province, South China, where it co-occurs with Xystridura. Fletcher et al. (2005, fig. 2) assigned material from the Acadoparadoxides harlani Zone of the lower Braintree Member of the Chamberlain's Brook Formation ("Harlani shales") at Braintree, eastern Massachusetts, to this species, but this assignment awaits confirmation from better preserved material (see Geyer \& Landing 2001).

Condylopyge eli Geyer, 1998 was first described from the Marocconus Zone ${ }^{1}$ of the Jbel Wawrmast Formation in the Moroccan Atlas ranges (Geyer 1990a). Subsequent reports of the species came from the Braintree Member ("Easter Cove Manganiferous Member"; see Landing 1992 and Landing \& Westrop 1996, for West Avalonian stratigraphic nomenclature) of the Chamberlain's Brook Formation on Cape St. Mary's Peninsula of southeastern Newfoundland (Fletcher 2003). Fletcher (2003) also assigned slightly different specimens from the Jigging Cove Member ("Branch Cove Member") of the uppermost Brigus Formation at Easter Cove to the species, interpreting them as earlier forms in the lineage. It should be noted that this author distinguished the two levels biostratigraphically, placing the Jigging Cove Member into the Marocconus Zone, whereas the Braintree Member ("Easter Cove Member") is placed into the Kiskinella cristata Zone (the zonal boundary being slightly below the lithostratigraphic boundary). The co-occurrence of Condylopyge eli with the index species Marocconus notabilis (Geyer, 1988) in Morocco would create uncertainties in this correlation unless the biostratigraphical distinction in Newfoundland was triggered by differences in litho- and biofacies, and/or the determination of Marocconus notabilis in the section in Avalonian Newfoundland is incorrect. In fact, a serrate ventral pygidial rim has not been detected in the Moroccan material.

Material tentatively assigned to Condylopyge has been reported recently from the Leny Limestone (Fletcher \& Rushton 2007). Fletcher \& Rushton (2007) suggested that the species appears to occur as well in Siberia, figured as "Condylopyge carinata vicina" by Yegorova \& Savitsky (1976, pl. 50, fig. 12). It should be noted, however, that this material comes from the Kounamkites Zone of the River Nekekit area.

\section{Bathynotid occurrences}

The utility of Bathynotus for intercontinental correlation was shown by a comprehensive revision by Webster (2009) and has also been emphasized by Peng et al. (2009). The co-occurrence of Bathynotus holopygus (Hall, 1859)

\footnotetext{
${ }^{1}$ It had been detected that the name Cephalopyge Geyer, 1988 for the trilobite genus and the eponymous zone is a junior homonym of Cephalopyge Hanel, 1905, a Recent phylliroid nudibranch. The first author of this article was aware of these circumstances and had started preparation of a short manuscript in which the name would have been changed and some of the morphological details of Cephalopyge further scrutinized. In an unfortunate act of nomenclatural piracy, a new name, Marocconus, has been proposed by Özdikmen (2009) without the customary courtesy of making contact with the original author or to other authors affected by similar renaming in his article [Özdikmen, H. 2009. Nomenclatural changes for Twenty trilobites [sic] genera. Munis Entomology \& Zoology 4(1), 155-171].
} 
and Bathynotus kueichouensis Lu, 1964 (in Wang et al. 1964) in the same strata as Ovatoryctocara granulata in the lowermost Kaili Formation of southeastern Guizhou and coeval strata in the western Hunan, Hubei, and Anhui provinces has been acknowledged with the Ovatoryctocara granulata-Bathynotus holopygus Zone of the stratigraphic scheme in the slope facies of South China (Yuan et al. 2001, Zhao et al. 2008). A further species in this stratigraphic interval is Bathynotus elongatus Zhao, Gong \& Huang, 1987. In addition, Bathynotus kueichouensis was also reported from the Quruqtagh region of Xinjiang, northwestern China, while B. nanjiangensis (Zhang, 1981) is known from the Shaylik Formation at the Wushi Phosphorus Mine, Kalpin area, Xinjiang. Zhao et al. (1990) revised Bathynotus from the Kaili Formation of eastern Guizhou and confirmed the status of only B. kueichouensis ( $\mathrm{Lu}$ in Wang et al., 1964), B. gaotanensis (Zhang \& Li, 1984), and B. elongatus (Zhao, Gong \& Huang, 1987) of the former six established Chinese species; the new species $B$. sinensis Zhao \& Huang, 1990) was also introduced. Despite their scattered occurrence in such provinces as Xinjiang, Hubei, Hunan, Guizhou, and Zhejiang, all of these species appear to occur together with the latest species of Redlichia or in coeval strata.

Bathynotus holopygus has its type locality in the anoxic/strongly dysoxic slope facies of the lowest Parker Formation of northwestern Vermont (originally assigned to the now abandoned Georgia Formation of Vermont; Hall 1859). These specimens are clearly transported (Landing 2007, Landing et al. 2007). Bathynotus holopygus has been subsequently reported from the uppermost Olenellus Zone in the Pioche Shale in Nevada (Palmer 1998), but these specimens have been revised to $B$. kueichouensis (Webster 2009). A form assigned as B. cf. holopygus was reported from the so-called Sandover Beds (= Arthur Creek Formation) of Ordian age of the Elkedra area of the Australian Northern Territory (Öpik 1956, 1975). Shergold \& Whittington (2000) referred a newly discovered specimen of those trilobites to B. holopygus, but this has also been revised to B. kueichouensis (Webster 2009); it suggests a conclusive correlation with the Kaili Formation and thus between Australia and South China.

In Siberia, six species of Bathynotus have been described. These include B. namanensis (Lermontova, 1940), B. anabarensis (Lazarenko, 1958) and B. angularis (Ogienko, 2001) from the lower Amgan of the Siberian Platform, B. granulatus (Lermontova, 1940) from the Minusinsk area of the West Sayan, B. fortis (Semashko, 1969) and B. rotundus (Semashko, 1969) from the Amgan Mundybash Formation of the Batenev Ridge/Kuznetsk Alatau of the Sayan-Altay Fold Belt, where they are associated with genera such as Erixus (formerly Schistocephalus) (see also Semashko in Chernysheva 1971). The two species from the Mundybash Formation, Bathynotus fortis and
B. rotundatus are known from small and probably immature specimens only and have been regarded as unidentifiable at species level (Webster 2009). Astashkin et al. (1997) showed that B. anabarensis Lazarenko, 1958 from the Shumnoy Formation of the Igarka area of northwestern Siberia was found in the late Amgan Tomagnostus fissus-Paradoxides sacheri Zone and thus appears to be younger than the other species. As noted by Peng et al. (2009), nearly all of the species are imperfectly preserved. However, we deem the taxa to be species of the genus Bathynotus. Bathynotellus yermolaevi Lermontova, 1940, the type species of Bathynotellus, was regarded as a junior synonym of Bathynotus holopygus by Peng et al. (2009). Despite the similarity with young specimens of $B$. holopygus, Bathynotellus yermolaevi bears several characters that distinguish the species, regardless of size differences of the most similar specimens. We concur with Webster (2009) and regard B. yermolaevi as a valid species distinct from B. holopygus and the other species of Bathynotus.

Bathynotus has been regarded as fairly aberrant in its morphology, particularly in the course of the rostral sutures (Whittington 1988). It can be shown that several trilobites closely related to Bathynotus but with a less bizarre morphology, such as Onaraspis Öpik, 1968 and Myopsolenites Öpik, 1975, are further members of the Bathynotidae. All are characterized by a strongly developed rostrohypostomal plate, a fairly large pygidium with a macropleural segment and two to four micropleurid segments posterior to it (Elicki $\&$ Geyer, submitted). All of these genera and their species occur in a fairly restricted stratigraphic interval which correlates with the stratigraphic range of the Bathynotus holopygus-B. granulatus-B. kueichouensis clade. Thus, these species may be used for additional calibration of the suggested correlation. These species include: Myopsolenites altus (Liñán \& Gozalo, 1986) from the early Agdzian ("Bilbilian") Hamatolenus ibericus Zone of northern Spain and from the Marocconus Zone of the lower Jbel Wawrmast Formation in the Moroccan Anti-Atlas range (first described as Myopsolenites boutiouiti Geyer \& Landing, 2004; see Elicki \& Geyer, submitted, for details); Myopsolenites palmeri Parnes, 1971 from the Timna Formation of Israel and the Burj Formation of Jordan; a new species of Myopsolenites from the Burj Formation of Jordan (Elicki \& Geyer, submitted); Myopsolenites kielciensis (Bednarczyk, 1970) from the Holy Cross Mountains in Poland (see Zylinska \& Masiak 2007). The occurrence of Myopsolenites altus from the Valdemiedes Formation of the Iberian Chains in the Hamatolenus ibericus Zone either indicates that it may be slightly older than the other species or that the onset of Paradoxides (Acadoparadoxides) mureroensis is indeed slightly later than that of Marocconus notabilis, as suggested by the co-occurrence with Shergoldiella and new results from the Tarhoucht section, eastern Anti-Atlas, Morocco (G. Geyer \& A. Vincent, unpubl.). 
Onaraspis adusta Öpik, 1968 and Onaraspis somniurna Öpik, 1968 were described from the Ordian of Western and central Australia, respectively. Onaraspis rubra was described by Jell (in Bengtson et al. 1990) from the Moodlatana Formation of South Australia and tentatively correlated with the northern Australian Ordian Stage. These strata are now regarded as part of the Ordian/Early Templetonian Stage (see Kruse et al. 2004, pp. 18, 19 for detailed discussion).

In this context, it needs to be emphasized that Redlichia guizhouensis, originally described from the middle part of the Lunwangmiaoan of South China and characteristic of the R. guizhouensis Zone of the platform facies (Zhou in Lu et al. 1974, Yin \& Li 1978, Zhou \& Yuan 1980, Peng \& Babcock 2001), occurs in the Wirrealpa Limestone of South Australia (Jell in Bengtson et al. 1990, Paterson \& Brock 2007). Zhang (1985, 2003) and Jell (in Bengtson et al. 1990) considered $R$. guizhouensis to be a possible synonym of R. nobilis Walcott, 1905. If so, the R. guizhouensis Zone of the South China Platform is a direct equivalent of the R. nobilis Zone of the North China continent.

\section{Additional taxa from the Ovatoryctocara granulata level}

Even more than Oryctocephalus indicus, Ovatoryctocara granulata can be placed into a stratigraphic context with auxiliary key taxa such as Kiskinella cristata Romanenko \& Romanenko, 1962 and Eoagnostus roddyi Resser \& Howell, 1938. Eoagnostus roddyi, also known as Peronopsis roddyi and originally described from the Lower Cambrian Kinzers Shale of Pennsylvania, would be an extremely helpful index fossil if confidently identified. In addition to the occurrence in the Kinzers Shale, the Taconic Sequence of the New York State (see Rasetti \& Theokritoff 1967) and the Henson Gletscher Formation of North Greenland, it has been reported from the Jigging Cove Member ("Branch Cove Marl Member") of the Brigus Formation in southeastern Newfoundland (Fletcher 2003). Yegorova et al. (1976, pl. 44, figs 22, 23) figured specimens as "Peronopsis aff. inarmata Hutchinson, 1962", which Fletcher (2003) also assigned to $E$. roddyi. This material comes from the Oryctocara Zone of the Nekekit River area. If the assignment is correct, occurrences of $E$. roddyi would permit correlation from Laurentia into western Avalonia and Siberia. However, only imperfectly preserved pygidia are figured by Yegorova et al. (1976). In addition, the two pygidia are identified as "Peronopsis aff. integra (Beyrich, 1845)" in the descriptive section by Yegorova et al. (1976, p. 66). Two additional specimens are referred to "Peronopsis aff. integra (Beyrich, 1845)" on pl. 49, figs 8 and 9. The cephalon on pl. 49 , fig. 8 certainly does not represent Eoagnostus roddyi; the pygidium (pl. 49, fig. 8) also belongs to a diffe- rent taxon and almost certainly to another species than the pygidia on pl. 44. By contrast, the short description of " $\mathrm{Pe}$ ronopsis aff. inarmata Hutchinson, 1962" by Yegorova et al. (1976, p. 66) refers to two cephala and one pygidium figured on pl. 45, figs 1-3. These specimens, however, certainly do not belong to Eoagnostus roddyi.

The first/lowest occurrence of Eoagnostus roddyi in the Easter Cove Section coincides with that of Ovatoryctocara granulata. However, Eoagnostus roddyi is also present in the overlying Braintree Member ("Easter Cove Member") of the lower Chamberlain's Brook Formation (Fletcher 2003), whereas it is found in the Henson Gletscher Formation only in strata immediately below the first specimens of O. granulata.

These occurrences make it difficult to accept Eoagnostus roddyi as a potential index fossil for a GSSP, since it suggests different biozones in several regions. The suggested morphologic plasticity and variation in different areas is difficult to reconcile and a careful restudy on a global scale is needed before the identification as a single species can be accepted unequivocally.

The occurrences of Ovatoryctocara granulata in the Jigging Cove Member ("Branch Cove Marl Member") of the uppermost Brigus Formation at Easter Cove, southeastern Newfoundland, are underlain by shales with Hamatolenus (Hamatolenus) cf. meridionalis Geyer, 1990 [Fletcher 2006, pl. 27, fig. 35, described as "Hamatolenus (H.) sp. aff. H. (H.) marocanus (Neltner, 1938)"]. Hamatolenus $(H$.$) meridionalis is known from the lower$ Marocconus Zone of the shaly facies of the Jbel Wawrmast Formation in the western Anti-Atlas (Geyer 1990b). This zone marks the peak of the second transgressional development near the base of the traditional Middle Cambrian in the Mediterranean Realm of West Gondwana (Geyer \& Landing 1995, 2006; Landing et al. 2006). It can be correlated fairly precisely into all regions in West Gondwana with a fairly fossiliferous Lower-Middle Cambrian transition, such as Spain, southern France, Sardinia, Turkey, Israel and Jordan. Remarkably, this zone and coeval strata yield the earliest species of Paradoxides s.l. in such regions as Iberia, France, Germany, Sardinia, and Turkey.

It has been claimed that the Ovatoryctocara granulata assemblage in the Kuonamka Formation shows a high degree of endemism and apparently long ranges so that a direct intercontinental correlation from this stratigraphic interval in northeastern Siberia is difficult (e.g., Zhao et al. 2008, Yuan et al. 2009). Characteristic species such as Oryctocara ovata, O. angusta, Pagetia horrida and Pagetides spinosus are of little help for correlation. Pagetia horrida indicates some of the severe problems which arise from the strong facies differentiation on the Siberian Platform. It is known to occur in the Anabaraspis Zone of the upper Toyonian in the Yudoma-Olenek Facies region, but also as well in the lower Amgan in the Anabar-Sinyaya 
Facies region (see Astashkin et al. 1991, Korovnikov 2001). An indication of the diachronous FAD of Paradoxides s.l. is also provided by the $O$. granulata Zone because it yields "Paradoxides" eopinus, the oldest Paradoxides species on the Siberian Platform.

The Henson Gletscher section yields Neopagetina rjonsnitzkii (Lermontova, 1940), first described from the (at that time) terminal Lower Cambrian of the eastern Siberian Platform. In the Henson Gletscher Formation, this species co-occurs with Ovatoryctocara and with Protoryctocephalus arcticus. As discussed above, Oryctocephalus vicinus, a species with a cranidium virtually indistinguishable from that of Protoryctocephalus arcticus, occurs in Siberia in the lower Amgan Ovatoryctocara Zone of the Kuonamka Formation on the Olenek Uplift. Protoryctocephalus arcticus has quite a long range in North Greenland. It ranges from below Arthricocephalus into the upper part of the formation where it occurs with Pagetides elegans. It should be mentioned that the Henson Gletscher material of Neopagetina rjonsnitzkii presents minor differences in morphology when compared with the Siberian specimens (as detailed by Blaker \& Peel 1997, p. 43). Nevertheless, the correlation between the Ovatoryctocara level in Greenland and the lowermost Amgan in Siberia is reconfirmed by the occurrence of Pagetides elegans in the upper part of the Ovatoryctocara ranges and that of Eoagnostus roddyi with Arthricocephalus chauveaui. Pagetides elegans characterizes the upper part of the "Pagetides faunula" of the Taconic sequence where it occurs with the youngest species of Olenellus (Rasetti 1967) as it does in North Greenland.

It has recently been argued that the distribution of Ovatoryctocara is not as wide as that of "Oryctocephalus indicus" (Yuan et al. 2009) whereas the contrary is in fact the case. The recognition of a second species of Ovatoryctocara, O. yaxiensis Yuan, Zhao, Peng, Zhu \& Lin, 2009, has even improved the utility of Ovatoryctocara, given the stratigraphic references of the Greenland sections, because its common occurrence provides an additional stratigraphic control. In addition, O. yaxiensis possibly also co-occurs with $O$. granulata in Siberia, which would re-inforce the recognisability of this stratigraphic level.

One of the problems with the stratigraphic range of Ovatoryctocara granulata, and particularly its FAD, is the slight facies change from the top Toyonian shallow water carbonates of the lower Kuonamka Formation (Anabaraspis splendens Zone) to the apparently deeper marine shaly carbonates at the base of the overlying Amgan in eastern Siberia. This change, however, is gentle in northeastern Siberia and in the Molodo section, proving that a distinct hiatus does not exist. Nevertheless, a condensation is obvious so that the Ovatoryctocara granulata Zone in the Molodo section measures only ca $6.7 \mathrm{~m}$ (see Shabanov et al. 2008a).
In summary, the range of Ovatoryctocara granulata can be directly correlated from Siberia into northwestern Laurentia, South China, and southwestern Avalonia, linking four Cambrian continents. The sections in southwestern Newfoundland suffer from a relatively strong structural deformation and a certainly incompletely preserved range of $O$. granulata. Despite condensed sequences, the sections in northeastern Siberia appear to depict the true range of $O$. granulata. The not infrequent occurrences of specimens identified as $O$. granulata in Guizhou are not yet fully studied, and the FAD of $O$. granulata needs to be critically analyzed. Co-occurring trilobites in North Greenland, Guizhou, and northeastern Siberia permit a convincing cross-correlation of the $O$. granulata level. The faunas of the Henson Gletscher Formation of North Greenland provide data for a correlation into other parts of Laurentia, Antarctica, and the Sayan-Altay Fold Belt, whereas the occurrences in Newfoundland permit a relatively precise correlation into West Gondwana, particularly the Moroccan Atlas ranges. From there, it is possible to correlate into other regions of West Gondwana (and peri-Gondwana) such as Spain, Sardinia, Germany, Turkey, Israel, and Jordan. The West Gondwanan sections tie the critical stratigraphic level into Baltica (although the correlation has to be based on taxa pending taxonomic revision). The South China and North China continental slices share critical faunas of the traditional Lower-Middle Cambrian boundary interval. Finally, indirect correlation permits the tying of Eastern Gondwana to South China and West Gondwana.

\section{Oryctocephalus indicus}

The Oryctocephalus indicus level has been discussed extensively for more than a decade (e.g. Sundberg et al. 1999; Yuan et al. 1999; Zhao et al. 2001, 2004; McCollum \& Sundberg 2002) and is not reviewed here in detail. This FAD of Oryctocephalus indicus is presently favoured by a slight majority of the ISCS Members for defining the base of a global Series 3 (Sundberg 2009) despite the intrinsic problems related to the species.

Oryctocephalus indicus was introduced as Zacanthoides indicus from the Spiti region of the Tethyan Himalaya of northern India (Reed 1910) and is based on conspicuously distorted material (see Jell \& Hughes 1997); in a strict sense the species cannot be identified from other areas without certain reservations despite the coincident "rediscovery" of the species by Jell \& Hughes (1997), Sundberg \& McCollum (1997) and Yuan et al. (1997). Geyer (2006) emphasized that Reed (1910) in the same article in which he introduced Zacanthoides indicus described an "Oryctocephalus cf. reynoldsi" which was placed into synonymy with $O$. indicus by Jell \& Hughes 
(1997) and almost certainly represents the same species. This only serves to illustrate the difficulties associated with determination of the material. In the context of the boundary discussions and a fine-scaled correlation based on material assigned to $O$. indicus, these deficiencies in the recognition of delicate details are fundamental for the concept of a GSSP based on such a taxon.

Well-preserved and amply studied material assigned to $O$. indicus is known from the Kaili Formation in southeastern Guizhou (Yuan et al. 2002; Zhao et al. 2004, 2007). Together with comparable material recovered from the Emigrant Formation of the Split Mountain section and coeval strata of other sections in western Nevada (Sundberg \& McCollum 1997, 2003), it has been used as the main key for (semi-)global correlation, although the assignment of the Laurentian material was temporarily challenged (e.g. Zhao et al. 2004). Further material assigned to $O$. indicus is known from Korea (as Oryctocephalus kobayashii Saito, 1934; see discussion in Sundberg \& McCollum 1997) and possibly from Yunnan Province, South China (see Luo et al. 2009). The material from the Kaili Formation is the best preserved material assigned to the species thus far. Unfortunately, a detailed analysis of its stratigraphic range with respect to morphological variation is still lacking, and apparent morphological plasticity and post-burial deformation may be reflected in taxonomic splitting into subspecies. However, Sundberg et al. (this volume) provide a detailed analysis of the Ovatoryctocara-Oryctocephalus indicus boundary beds in the Kaili Formation at the Wuliu-Zengjiaya section of Guizhou with detailed analysis of the faunal turnover and the morphology of the trilobites in this interval.

The Split Mountain section includes other trilobites in the interval with $O$. indicus which might be helpful for interregional and even intercontinental correlation, such as Paraantagmus latus. Paraantagmus latus was earlier described from the Paragraulos Zone of Huainan in the Anhui Province, China (Yuan \& Li 1999) but is known from the Split Mountain section only from a spot sample close to the base of the Amecephalus arrojosensis Biozone (just below the Oryctocephalus indicus Biozone). It also occurs, however, in the Monola Formation of the Saline Range, California. Euarthricocephalus nevadensis (originally introduced as Microryctocara nevadensis) ranges in Nevada from the Amecephalus arrojosensis Zone into the Oryctocephalus indicus Zone (Sundberg \& McCollum 2003) and is found in the Danzhaiaspis-Xingrenaspis Zone of the Kaili Formation in Guizhou (Yuan et al. 1997, 2002). By contrast, the identification of the Laurentian O. indicus Zone species Onchocephalites claytonensis from Tongren, South China, by Yuan \& Zhao (2004) has been shown to be incorrect (F.A. Sundberg, unpublished report to the ISCS Lower-Middle Cambrian GSSP Working Group).
Oryctocephalus reticulatus (Lermontova, 1940) from the Yudoma-Olenek facies region of the Siberian Platform has been regarded as a junior synonym of $O$. indicus by a number of authors following Korovnikov (2001). The material of $O$. reticulatus figured from the boundary candidate section at the Molodo River differs from the Kaili specimens assigned to $O$. indicus mainly by the tendency to show a slightly more curved anterior margin of the cranidium and a generally slightly larger distance between S3 and S4. However, the specimens from the Kaili Formation are strongly flattened in black shales, which may partly explain the difference in the anterior border and the width between the lateral glabellar furrows S3 and S4. A final consensus as to whether or not the species are synonyms is not yet achieved, a factor which plays a major role in the utility of $O$. indicus as the index fossil for a GSSP.

Oryctocephalus reticulatus occurs in the Kounamkites Zone of the Amgan Stage. In addition, O. reticulatus is known from the middle part of the Amgan from at least two localities in the Batenev Ridge of Sayan-Altay Foldbelt (Chernysheva 1971). However, as pointed out by F. Sundberg (unpubl. comm. 2007 and 2011), some of the illustrated specimens from the Siberian Platform and the Sayan-Altay Foldbelt may be assigned to $O$. indicus, O. nyensis, or to an undescribed new species, and the holotype of Oryctocephalina reticulata (Lermontova 1940, pl. 42, fig. 3) differs in some characters from specimens subsequently assigned to Oryctocephalus reticulatus.

As mentioned above, one horizon (represented by GGU collection 482335) from upper part of the Henson Gletscher Formation in the Fimbuldal section (Fig. 5) yielded a fauna with Oryctocephalus cf. indicus (Fig. 19A) and Olenoides cf. procerus (Fig. 9N). Despite the tentative assignment, these occurrences parallel the biostratigraphy known from the sections in the Batenev Ridge of the Sayan-Altay Fold Belt. Some Siberian specimens assigned to Oryctocephalus reticulatus by Yegorova et al. (1976, pl. 49, figs 14-16) appear to represent O. americanus Sundberg \& McCollum, 2003, described from the Amecephalus arrojosensis Biozone in Nevada (F. Sundberg, pers. comm., March 2005). Nevertheless, the perceived morphologic plasticity of Oryctocephalus indicus needs clarification (see F. Sundberg, communication on Lower-Middle Cambrian GSSP Working Group website, http://www.geology.ewu.edu/mccollum/workinggroup/ correspondence.htm).

As emphasized by Geyer (2006), another critical point concerns the subsequent appearances of the various species of Oryctocephalus. In the Split Mountain section, five species of Oryctocephalus have been identified of which Oryctocephalus americanus occurs from the base of the Amecephalus arrojosensis Zone to about the base of the O. indicus Zone. Oryctocephalus orientalis is only known from a single horizon in the upper A. arrojosensis Zone as 
Bulletin of Geosciences • Vol. 86, 3, 2011

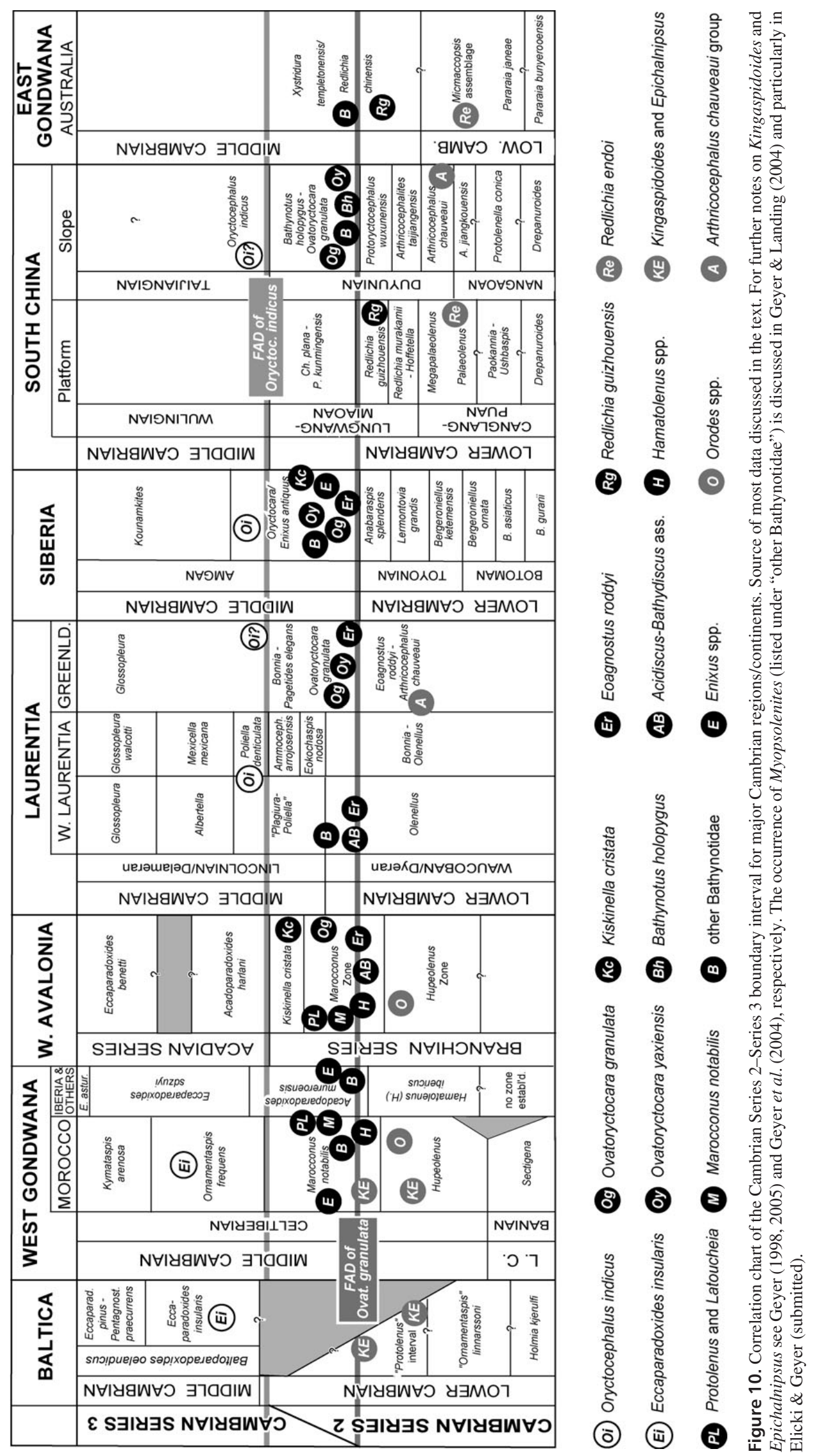


well as an unidentified species of Oryctocephalus. The first appearance of Orytocephalus indicus marks the base of the eponymous zone. Oryctocephalus orientalis was reported from South China and South Korea as well. In South Korea, however, O. orientalis occurs together with $O$. indicus, whereas in Guizhou $O$. orientalis occurs above $O$. indicus. It is yet unclear whether the species tend to occur at different times in the various regions, whether the ordinary regional biostratigraphies are unable to reveal the true ranges of the two species, or whether misidentifications lead to the different ranges.

The second, and potentially most problematic aspect is that the FAD level of $O$. indicus as seen in South China and Laurentia cannot be identified with sufficient precision to establish a practical boundary in Cambrian continents such as Avalonia, West Gondwana, and Baltica (Fig. 10). These are continents which in part have complex faunal associations across the traditional Lower-Middle Cambrian boundary interval and which gave rise to the first distinction between Lower (= early) and Middle (= mid) Cambrian faunas. In these regions, the Paradoxides concept for the Middle Cambrian lower boundary has been applied, and this concept is the oldest and thus most relevant traditional concept for the Lower-Middle Cambrian boundary (Brøgger 1882, 1886). Thus, the need to recognize the Series 3 and Stage 5 lower boundary in these continents with a high degree of certainty renders the $O$. indicus level as unacceptable.

\section{Isotopic signatures}

Fine-scale stratigraphic investigations based on isotopic signatures have been rare for the Cambrian Series 2-Series 3 boundary interval. However, recent data on C-, O- and Sr-isotopes exist for the traditional Lower-Middle Cambrian boundary interval in the Cantabrian Mountains, Iberia (Wotte et al. 2007), for the Lower-Middle Cambrian boundary interval on the Yangtze Platform (Guo et al. 2010), and for parts of Laurentia (Montañez et al. 2000).

The data from the Cantabrian Mountains show a long-term trend towards higher $\delta^{13} \mathrm{C}$ values starting in the basal Celtiberian (equivalent to the Iberian Hamatolenus ibericus Zone) and punctuated by several positive excursions in the Acadoparadoxides mureroensis Zone. For the Montagne Noire area, southern France, Wotte et al. (2007) revealed two minor positive shifts in the lowermost Celtiberian and two stronger ones higher up in equivalents of the Marocconus notabilis Zone. Similar trends have been reported from the Lower-Middle Cambrian transition in Siberia (Brasier et al. 1994a, Brasier \& Sukhov 1998) and Australia (Donnelly et al. 1988, Shergold 1995, Ebneth et al. 2001, Lindsay et al. 2005). Based on these data, Lindsay et al. (2005) proposed direct correlation of early Middle Cambrian $\delta^{13} \mathrm{C}$ trends between the distinct positive excursion in the Ordian-early Templetonian Giles Creek Dolostone of the Amadeus Basin and similar signatures in the coeval middle Gum Ridge Formation of the Georgina Basin, the upper Montejini Limestone of the Wiso Basin, and the upper Tindall Limestone of the Daily Basin with an early Amgan peak in Siberia detected by Brasier \& Sukhov (1998).

A marked negative $\delta^{13} \mathrm{C}$ excursion has been detected at the (traditional) Lower-Middle Cambrian boundary of Laurentia (Montañez et al. 2000). The beginning of this large-magnitude shift to negative $\delta^{13} \mathrm{C}$ values lies just beneath an extinction level associated with the upper boundary of the Olenellus Zone (Palmer 1998). The hypothesis that anoxic waters developed below the surface mixed layer at least locally during the latest Early Cambrian, before the major transgressions at the Lower-Middle Cambrian boundary interval is well supported by sulphur isotope data (Hough et al. 2006).

Of particular interest in this context is the question as to whether or not this negative carbon isotopic excursion is paralleled on the Yangtze Platform. According to Guo et al. (2005), the Lower-Middle Cambrian transition in Guizhou Province, South China, showed no distinct shift in the carbon-isotopic composition. Instead, these authors reported decreasing $\delta^{13} \mathrm{C}$ values from positive values in the late Early Cambrian to negative values in the early Middle Cambrian. Studies for the same stratigraphic interval in the Wangcun section of the Hunan province indicated that a distinct negative shift of $\mathrm{ca} 4 \%$ in $\delta^{13} \mathrm{C}$ values exists across the Qiangdongian-Wulingian transition (Zhu et al. 2004). These authors also reported excursions across the same transition in the Anhui Province, North China, although biostratigraphic data supporting a fine-scale correlation of these areas are scarce. Zhu et al. (2004) proposed a direct correlation of the Qiangdongian-Wulingian transition with the Olenellus-Plagiura-Poliella boundary in Laurentia based on this negative excursion. The distinct negative shift in $\delta^{13} \mathrm{C}$ values has been termed the ROECE event (Redlichiid-Olenellid Extinction Carbon Isotope Excursion; Zhu et al. 2006, 2007) and is thought to reflect the perturbations of the global carbon cycle during the Cambrian Series 2 to Cambrian Series 3 transition.

In a recently published article, Guo et al. (2010a) were now able to confirm such a negative carbon isotope excursion for Cambrian Series 2-Series 3 interval in the Guizhou province of South China. In the Jianshan and the Wuliu-Zengjiayan sections, they recorded $\delta^{13} \mathrm{C}$ values with a progressive decrease around $+3 \%$ upwards to a $\delta^{13} \mathrm{C}$ minimum with values as low as $-6.9 \%$ at the proposed boundary level with Oryctocephalus indicus, and a return to $\delta^{13} \mathrm{C}$ values between 0 and $+1 \%$ in the upper part of the Kaili Formation in these sections. Guo et al. (2010a) ascribed the negative shift to the base of the Oryctocephalus 
indicus Zone. The $\delta^{13} \mathrm{C}$ minimum is believed to coincide with a transgressive event that flooded the shelf area with ${ }^{13} \mathrm{C}$ depleted basinal anoxic bottom water.

It should be noted, however, that the striking negative excursion recorded in the Jianshan section is poorly controlled biostratigraphically and the base of the Oryctocephalus indicus Zone in the Wuliu-Zengjiayan section shows only a small-scale excursion. Moreover, the Ovatoryctocara granulata-Bathynotus holopygus Zone and the Oryctocephalus indicus Zone were confused in the publication (see also Guo et al. 2010b), so that in reality an even stronger shift in carbon isotopes in the Wuliu-Zengjiayan section coincides with the base of the Ovatoryctocara granulata range. It remains unclear, whether this negative carbon isotopic excursion within $4 \mathrm{~m}$ below the FAD of $O$. indicus is identical with the excursion reported in several additional publications, such as by Yang et al. (2003), Guo et al. (2005), and Lin (2009, 2010, 2011). In addition, a recent report by Wotte et al. (2011) suggests that both proposed boundary candidates appear to have $\mathrm{C}$ excursions as exemplified by a positive $\delta^{13} C_{\text {carb }}$ peak in the Molodo River candidate section, Siberian Platform, situated slightly below the Ovatoryctocara granulata Zone.

Oxygen isotope and trace element ( $\mathrm{Ca}, \mathrm{Mn}$ and $\mathrm{Sr})$ data reported by Wotte et al. (2007) from the Cantabrian Mountains and the Montagne Noire indicate that the $\delta^{13} \mathrm{C}$ trends are unlikely to be diagenetic features. It is worthy of note that the authors emphasized a lack of correlation with obvious relative sea-level fluctuations, facies changes as documented in the sections, as well as with possible benthic community dynamics. Hence, these isotopic signatures may have a potential for global stratigraphic correlation, and the stratigraphic position of the ${ }^{13} \mathrm{C}$ fluctuation is closer to the Ovatoryctocara granulata level than to that of Oryctocephalus indicus.

\section{Conclusions}

1. The moderately diverse trilobite faunas of the Henson Gletscher Formation of North Greenland, bracket the proposed Cambrian Series 2-Series 3 boundary interval and yield a number of trilobite taxa which enable a fairly precise correlation into other parts of Laurentia, and into other Cambrian continents.

2. Especially the occurrence of Ovatoryctocara granulata and O. yaxiensis in the Henson Gletscher Formation substantially improves the intercontinental recognition of the $O$. granulata level which characterizes a prime GSSP candidate. It enables a direct correlation from this part of Laurentia into western Avalonia, Siberia, and South China, and an indirect correlation into West Gondwana and Baltica.

3. The Bathynotidae provide a degree of utility as an auxi- liary tool for correlation of the Ovatoryctocara granulata level on a sub global scale.

4. The level with Oryctocephalus indicus cannot be located in a number of Cambrian continents with acceptable precision; this level is therefore unsuitable for defining a GSSP for the base of the Cambrian Series 3 and Stage 5.

5. Further support for the correlation utility of the base of the Ovatoryctocara granulata range comes from recent carbon isotope studies which indicate a striking negative excursion in sections of South China (termed the ROECE event) that probably parallels similar excursions in Laurentia. Although this appears to coincide with the range of Ovatoryctocara granulata, a second carbon isotope excursion has been determined near the base of the Oryctocephalus indicus Zone.

\section{Systematic palaeontology}

The abbreviation GGU indicates collections from Greenland made under the auspices of Grønlands Geologiske Undersøgelse (Geological Survey of Greenland, now a part of the Geological Survey of Denmark and Greenland). Individual type or figured specimens are identified by MGUH numbers and this material is deposited in the Geological Museum, Copenhagen, a part of the Natural History Museum of Denmark. The stratigraphic position of the GGU collections is indicated in Figs 4-6. Numbers and location of additional figured material are given in the text and in the figure captions.

Order Agnostida Salter, 1854

Family Peronopsidae Westergård, 1936

\section{Genus Eoagnostus Resser \& Howell, 1938}

Type species (by original designation). - Eoagnostus roddyi Resser \& Howell, 1938. Lower Cambrian, Kinzers Formation, near Lancaster, Pennsylvania, U.S.A.

Emended diagnosis. - Peronopsidae with elongate glabella; posteroglabella distinctly convex (tr.), rapidly sloping to fairly well-defined F3. F1 and F2 obsolescent to absent. Anteroglabella semi-effaced to effaced, barely rising from weakly developed to obsolescent axial furrows. Basal lobes transversely elongate. Pygidial axis strongly convex (tr. and sag.), F1 and F2 weakly developed, F3 obsolescent, posterior end of axis narrowly rounded, separated from border furrow by more than double sagittal width of posterior border.

Discussion. - Eoagnostus was regarded as a junior synonym of Peronopsis Hawle \& Corda, 1847 by Robison 

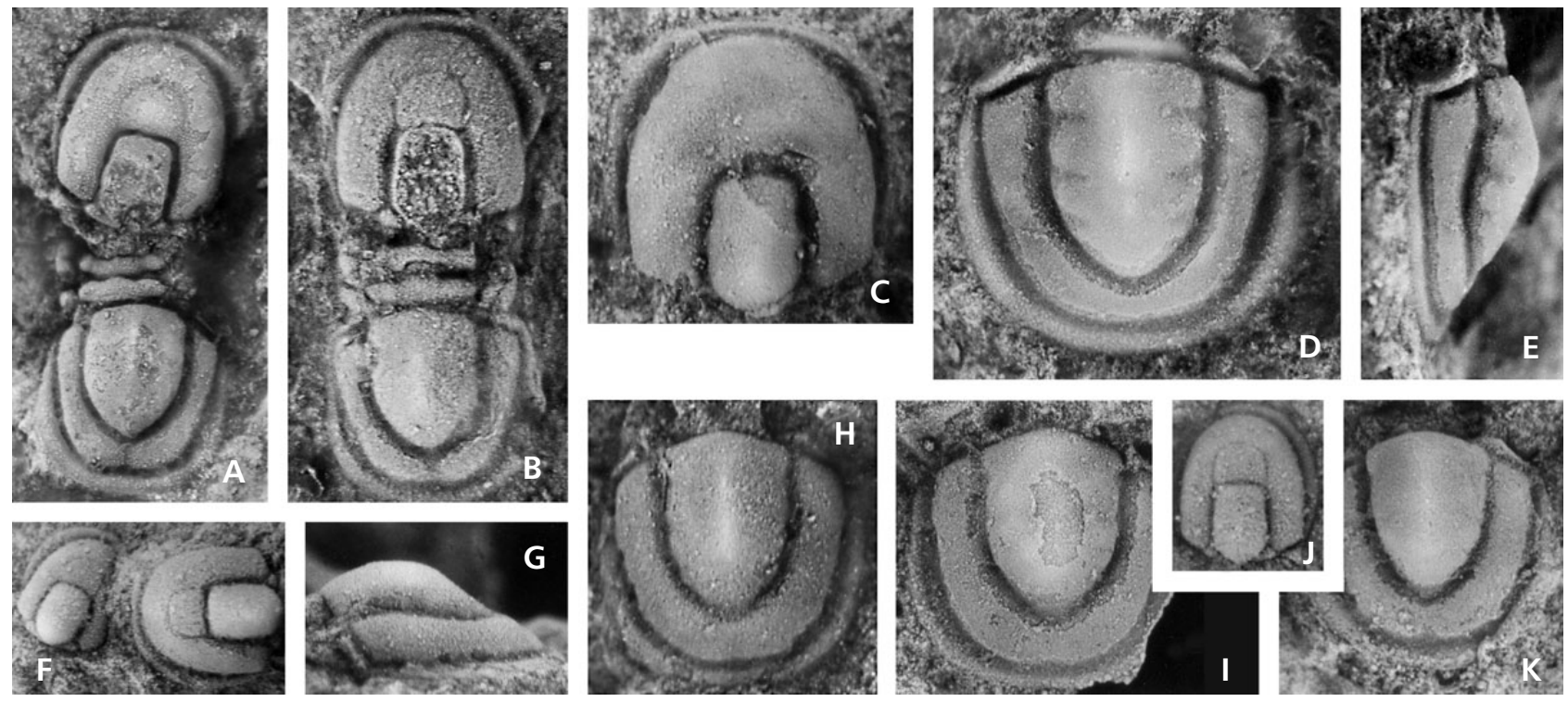

Figure 11. A-C, F-K - Eoagnostus roddyi Resser \& Howell, 1938, Henson Gletscher Formation. • A - dorsal carapace with slightly disarticulated cephalon, MGUH 29301 from GGU 298545, × 15. • B - dorsal carapace with slightly disarticulated cephalon, MGUH 29302 from GGU 298545 , × 15. - C - cephalon, MGUH 29303 from GGU 271750, × 17.5. • F - two cephala, MGUH 29304 and MGUH 29305 from GGU 298545 , × 15. $\bullet$ G, H - pygidium, MGUH 29306 from GGU 271750, × 18, left lateral and dorsal views. • I - incomplete pygidium, MGUH 29307 from GGU 271750 , $\times 20$. $・$ J - immature cephalon, MGUH 29308 from GGU 298545, × 12.5. $\bullet$ K - pygidium, MGUH 29309 from GGU $271750, \times 20$. D, E - Peronopsis sp., Henson Gletscher Formation, incomplete pygidium, MGUH 29310 from GGU collection 315107, dorsal and left lateral views, $\times 17.5$.

(1964) and a number of subsequent authors, including Blaker \& Peel (1997). In fact, both genera are quite similar, the only striking difference being a considerably effaced, faintly defined anteroglabella in Eoagnostus. Major reasons for the synonymization have been the poor preservation of the type material of the type species, Eoagnostus roddyi Resser \& Howell, 1938, and the supposed large morphological variation in this species. It can be shown, however, that the supposed range of variation is partly overestimated, whereas the effacement of the anteroglabella correlates with a reduction of convexity, so that the lateral profile of well-preserved cephala of Eoagnostus roddyi differs distinctly from that of a typical species of Peronopsis. Amongst other, not yet discussed features are slightly transversely elongate basal lobes and the shorter pygidial axis. Given the fairly large number of species placed within Peronopsis, Eoagnostus roddyi is perceived to lie outside the homogenous morphological core of this clade and should be regarded as representing a valid separate genus, despite the congruence in the pygidial morphology.

\section{Eoagnostus roddyi Resser \& Howell, 1938}

Figures 11A-C, 11F-K

1938 Eoagnostus roddyi sp. nov.; Resser \& Howell, p. 216, pl. 3, figs $1-4$.

1967 Eoagnostus roddyi Resser \& Howell, 1938. - Rasetti \& Theokritoff, p. 193, pl. 20, figs 15-19.
?1967 Eoagnostus acrorhachis Rasetti \& Theokritoff $n$. sp. - Rasetti \& Theokritoff, p. 194, pl. 20, figs 1-14.

?1967 Peronopsis sp. cf. P. primigenea (Kobayashi). - Rasetti \& Theokritoff, p. 195, pl. 20, figs 23-25.

1967 Peronopsis pygidium 1. - Rasetti \& Theokritoff, p. 196, pl. 20, figs 29, 30.

?1967 Peronopsis pygidium 2. - Rasetti \& Theokritoff, p. 196, pl. 20, figs 27, 28.

1986 Peronopsis sp. - Blaker, p. 70.

1994 Peronopsis roddyi. - Robison, p. 42.

1997 Peronopsis roddyi (Resser \& Howell, 1938). - Blaker \& Peel, p. 26, figs 13.1-13.7, 14.1-14.4, 14.6, 15, 16.2, 25.4, 25.5, 25.7.

non 1997 Peronopsis roddyi (Resser \& Howell, 1938). - Blaker \& Peel, p. 26, figs 13.8, 14.5, 14.7, 16.1, 16.3.

2005 Peronopsis roddyi (Resser \& Howell, 1938). - Geyer, p. 86, fig. 4.3 .

non 2005 Peronopsis roddyi (Resser \& Howell, 1938). - Geyer, figs 4.1, 4.2.

2008 Eoagnostus roddyi Resser \& Howell, 1938. - Naimark, p. 398.

Type material. - From the Kinzers Formation, near Lancaster, Pennsylvania, U.S.A., USNM 90796-90798, housed in the U.S. National Museum of Natural History, Washington, D.C.

Deposited material from the Henson Gletscher Formation. Freuchen Land section (Fig. 4), from GGU collection 
298545: complete or nearly complete carapaces under MGUH 23124-23128, 232811, 23282; four cephala under MGUH 23132-23135, two pygidia under MGUH 23140-23141. - Løndal section (Fig. 6), from GGU collection 271750: six cephala under MGUH 23129-23131, 23281, 23282, 29303, two pygidia under MGUH $23138-23139$.

Additional material. - Two dorsal carapaces, three cephala and two pygidia from GGU collection 298545: MGUH 29301, 29302, 29304, 29305, 29308; three pygidia from GGU collection 271750: MGUH 29306, 29307, 29309.

The following deposited specimens from GGU collection 315107 in Freuchen Land (Fig. 4) are excluded from E. roddyi: two cephala under MGUH 23136-23137, two pygidia under MGUH 23142-23143.

Discussion. - Blaker \& Peel (1997, pp. 24-27) presented an adequate description and discussion of Eoagnostus rod$d y i$ (as Peronopsis roddyi) and figured a number of specimens from the Henson Gletscher Formation which apparently confirmed the supposed enormous variation in the anteroglabella. The typical E. roddyi material is best exemplified by specimens from the Freuchen Land section (Fig. 4, GGU collection 298545) and the Løndal section (Fig. 6, GGU collection 271750). However, re-examination of the material suggests that some of the figured specimens do not represent Eoagnostus roddyi but belong to an un-described species of Peronopsis, which is morphologically close to Peronopsis primigenea (Kobayashi, 1939). These specimens are distinguished from $E$. roddyi by having (i) a considerably convex anteroglabella defined by a clearly incised furrow; (ii) a narrower and slightly shorter (sag.) posteroglabella; (iii) a more gently curved anterior border furrow; (iv) a narrower anterior and lateral cephalic border of quite uniform breadth; (v) a slightly more subacute posterior end of the pygidial axis; and (vi) slightly better developed furrows on the pygidial axis (Blaker \& Peel 1997, figs 13.8, 14.5, 16.3; one pygidium figured herein, Fig. 11D, E). These specimens come from GGU collection 315107 of the Freuchen Land section and are slightly younger than the true specimens of Eoagnostus roddyi.

A second species of Eoagnostus was described by Rasetti \& Theokritoff (1967) from the Taconic Sequence of the New York State under the name Eoagnostus acrorhachis. These authors noted a certain variation of the morphology of the anteroglabella from "faintly defined, rounded in front, to entirely effaced" (Rasetti \& Theokritoff 1938, p. 193). Blaker \& Peel (1997) examined the type material of both E. acrorhachis and E. roddyi and considered them to be conspecific. At least part of the type material is considerably affected by deformation so that a precise determination is difficult.
It should be noted that well-preserved and clearly determinable specimens of Eoagnostus roddyi are relatively sparse in the collections and almost restricted to the two mentioned samples. They come from levels well below the sandstone member of the Henson Gletscher Formation. The exclusion of the material from GGU collection 315107 from Eoagnostus roddyi restricts the proven range of this species in Greenland to a brief interval.

Family Hebediscidae Kobayashi, 1944

\section{Genus Pagetides Rasetti, 1945}

Type species (by original designation). - Pagetides elegans Rasetti, 1945 from the Lower Cambrian Ville Guay Conglomerate, Québec, Canada.

\section{Pagetides elegans Rasetti, 1945 \\ Figure 12A-L}

1945 Pagetides elegans Rasetti n. sp.; Rasetti, p. 313, pl. 1, figs $15-18$.

1948 Pagetides elegans Rasetti. - Rasetti, p. 11, pl. 1, figs $1-7$.

1967 Pagetides elegans Rasetti, 1945. - Rasetti, p. 64, pl. 5, figs 16-24.

1997 Pagetides elegans, Rasetti, 1945. - Blaker \& Peel, p. 38, figs 21-23, 25.1.

2005 Pagetides elegans Rasetti, 1945. - Geyer, p. 87, fig. 2.4-2.6.

Type material. - From Ville Guay Conglomerate (= Sillery Formation), near Lévis, Québec, Canada. Housed in the Laval University, Québec, No. 304a-c.

Deposited material from the Henson Gletscher Formation. - Freuchen Land section (Fig. 4), GGU collection 298553A, a complete enrolled carapace under MGUH 23189; GGU collection 298553: four cranidia under MGUH 23173-23176, two pygidia under MGUH 23185-23186; GGU collection 315110: two pygidia under MGUH 23187-23188. - Løndal section (Fig. 6), GGU collection 225709: two cranidia under MGUH 23168-23169; GGU collection 225712: two pygidia under MGUH 23181 and 23182; GGU collection 225714, pygidium under MGUH 23183; GGU collection 225714A, three cranidia under MGUH 23170-23172, two isolated thoracic segments under MGUH 23177-23178, adult pygidium under MGUH 23184, meraspid pygidium under MGUH 23190; GGU collection 218681: two pygidia under MGUH 23179 and 23180, cranidium under MGUH 29311.

Additional material. - Fimbuldal section (Fig. 5), GGU 

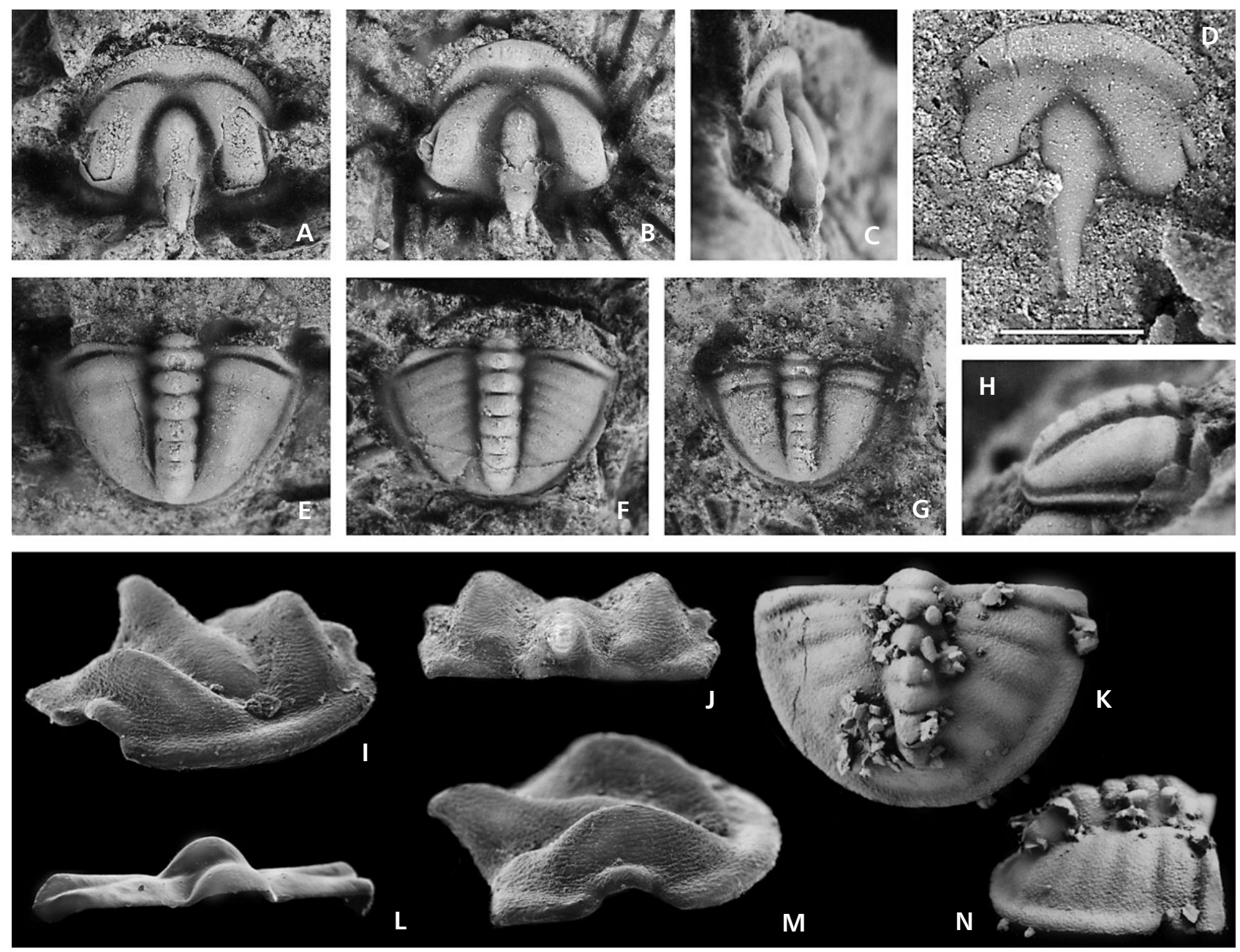

Figure 12. Pagetides elegans Rasetti, 1945, Henson Gletscher Formation. • A - cranidium, partly exfoliated, MGUH 23181 from GGU collection 225712, × 15. • B, C - cranidium, largely exfoliated, MGUH 23175 from GGU collection 298553, dorsal and left lateral views, $\times 12$. $・$ D - cranidium, partly covered by matrix, MGUH 29311 from GGU collection 218681, scale bar $1 \mathrm{~mm}$. $\bullet$ E-pygidium, internal mould, MGUH 23186 from GGU collection $298553, \times 15$. $\bullet \mathrm{F}$ - pygidium, partially exfoliated, MGUH 23185 from GGU collection $298553, \times 15 . \bullet \mathrm{G}-$ immature pygidium, MGUH 23181 from GGU collection 225712, $\times 17$. $\bullet \mathrm{H}$ - pygidium, internal mould with remains of test, lateral view, MGUH 23183 from GGU collection $225714, \times 17$. - I, J, M - immature cranidium, MGUH 23171 from GGU collection 225714A, oblique anterolateral, posterior and right lateral views, SEM photographs, $\mathrm{I}, \mathrm{M} \times 100, \mathrm{~J} \times 82 . \cdot \mathrm{K}, \mathrm{N}-$ immature pygidium, MGUH 23184 from GGU collection $225714 \mathrm{~A}$, SEM photographs, dorsal and right lateral views, $\times 45$. $\bullet \mathrm{L}$ - thoracic segment, MGUH 23178 from GGU collection 225714A, oblique anterolateral view, $\times 30$

collection 218681; Løndal section, GGU collections 225709, 225712, 225714; Lauge Koch Land section (Fig. 1D, E, locality 2; Blaker \& Peel 1997, fig. 9), GGU collection 271486; Freuchen Land section (Fig. 4), GGU collections 298553, 301346, 301349, 315110 (abundant), 315110A (abundant), and 315112.

Discussion. - Blaker \& Peel (1997) showed that the specimens from the Henson Gletscher Formation illustrate a variable species. Particularly, the expression of pygidial pleural furrows varies considerably, but remains relatively constant within the various assemblages. Additional characters which underwent notable variation include (i) the medial expansion of the anterior border in front of the glabella; (ii) the grade of tapering of the py- gidial axis; and (iii) the shape (i.e. ratio length/width) of the pygidium.

Based on this morphological variation, Blaker \& Peel (1967) regarded Neopagetina taconica Rasetti, 1967 from the Taconic Sequence of the New York State as a junior synonym of Pagetides elegans. However, the specimens of $N$. taconica present a robust morphological pattern which differs in a number of characters, such as the only faint medial expansion of the anterior border, which is thinner than in P. elegans; more forwardly extended cheeks; clearly impressed pleural furrows in the pygidium with a particularly well impressed furrow near the posterior end of the rhachis; and an obviously different type of scrobicules on the cephalic border. Thus, Pagetides taconica (Rasetti, 1967) is not considered a junior synonym of $P$. elegans herein. 


\section{Genus Neopagetina Pokrovskaya, 1960}

Type species (by original designation). - Pagetina rjonsnitzkii Lermontova, 1940 from the Kutorgina Formation of Gerbikan River, Dzhagdi, northern Siberia, Russia.

Remarks. - We follow the concept of Jell (1975) and regard Neopagetina Pokrovskaya, 1960 as a genus characterized by a narrow cephalic border without scrobicules, with a well developed occipital furrow, small librigenae, and a subquadrate pygidium with the pygidial axis distant from the posterior border furrow. The often cited absence of a terminal axial spine and the presence of clearly recognizable pleural furrows in the pygidium (Rasetti 1966b, Palmer 1968, Öpik 1975) are not regarded herein as diagnostic features on their own, but they are additional important characters that serve to distinguish the genera.

\section{Neopagetina rjonsnitzkii (Lermontova, 1940)}

Figure 13A-D, E?, F?, G-I, J-M?, O-Q

1940 Pagetina rjonsnitzkii Lerm. (MS); Lermontova, p. 121, pl. XXXV, figs 7, 7a, b.

1951 Pagetina rjonsnitzkii Lerm. - Lermontova, p. 27, pl. III, figs $7 \mathrm{a}, \mathrm{b}$.

1964 Neopagetina rjonsnitzkii (Lermontova, 1940). - Lazarenko in Lazarenko \& Demokidov, p. 177, pl. I, figs 22, 23, 25-27 (only).

non 1964 Neopagetina rjonsnitzkii (Lermontova, 1940). - Lazarenko in Demokidov \& Lazarenko, pl. I, figs 21, 24 (= Neopagetina pararjonsnitzkii Yegorova \& Shabanov in Savitskiy et al. 1972?).

1974 Neopagetina rjonsnitzkii (Lermontova). - Ogienko et al., p. 16, pl. I, figs 1-4.

1997 Pagetides rjonsnitzkii (Lermontova, 1940). - Blaker \& Peel, p. 41, fig. 24.

2001 Neopagetina rjonsnitzkii (Lermontova, 1940). - Ogienko \& Gurina, p. 94, pl. 1, figs 1-4.

Type material. - From Peleduy River area, central Siberian Platform. Housed in the Central Siberian Geological Museum, Siberian Branch of the Russian Academy of Science (UIGGM), Novosibirsk, Russia, No. 36/5156.

Deposited material from the Henson Gletscher Formation. - Fimbuldal section (Fig. 5), GGU collection 218610: five cranidia under MGUH 23191-23195, seven pygidia under MGUH 23196-23202); GGU collection 218611: dorsal carapace under MGUH 29312, three cranidia under MGUH 29318, 29319 and 29321, pygidium under MGUH 29320; GGU collection 482331: three cranidia under MGUH 29316, 29317 and 29323, pygidium under MGUH 29322 and, two protaspids under MGUH 29313 and 29314.
Freuchen Land (Fig. 4) section, GGU collection 301349: cranidium under MGUH 29315.

Additional material. - Abundant specimens in GGU collections 218610, 218611, 482322, 482328, 482329, and 482331.

Description. - Cranidium subsemicircular in outline. Glabella fairly convex (tr.), ca 65 percent cephalic length (except occipital spine), maximum width at across the occipital ring $\mathrm{ca} 30$ to 35 percent cranidial width across palpebral lobes, slightly tapering forward from the occipital ring towards about 85 percent across the frontal lobe; front gently rounded; S1 relatively short (tr.), moderately deep depressions slightly directed backward, confluent with the axial furrows and faintly connected across the glabella, slightly anterior to glabellar midlength; S2 short (tr.), moderately deep depressions normal to axis, confluent with the axial furrows and faintly connected across the glabella. Occipital furrow only visible as well impressed elongate pits adjacent to the axial furrows, distinctly rearward directed. Occipital ring and L1 fused to extend backwardly into a moderately long, stout occipital spine; occipital ring thus developed only as a narrow, rearward directed lateral band.

Axial furrows shallow to moderately well developed, relatively wide, somewhat sinuous in their course, poorly defined against fixigenae, distinctly shallower and narrower around frontal lobe. Preglabellar field relatively long (sag.) but affected by the forward swinging axial furrows so that it forms a slight depression between the preocular areas.

Fixigena transversely strongly convex and moderately convex exsagittally, rising considerably from posterior border and axial furrows, sloping less steeply towards the eye ridges and anterior border furrow, forming a tumescent portion at the highest elevation near the palpebral lobe; with small and low bacculae at posteroproximal corner; width across centre of palpebral lobes ca 120 to 130 percent maximum glabellar width. Palpebral lobe short (exsag. ca 20 percent cephalic length in adult individuals), slightly oblique to axis, gently arcuate or gently curved at ocular suture, highly in transverse section, narrowing considerably towards the anterior and posterior ends; anterior end curving slightly adaxially, in transverse line with centre of frontal lobe, posterior end about in transverse line with S2. Palpebral furrow a narrow incision slightly curved adaxially. Eye ridges faint and low, often obsolescent, gently curving into a more-or-less transverse direction towards the glabellar front, sometimes crossing axial furrows as a thin, obsolescent thread.

Anterior border relatively broad (sag.), slightly tapering laterally and with a distinct narrowing at a faint kink in the curvature of the margin in front of the palpebral lobes, moderately convex, considerably rising from border furrow, often with a slight median expansion. Anterior border 

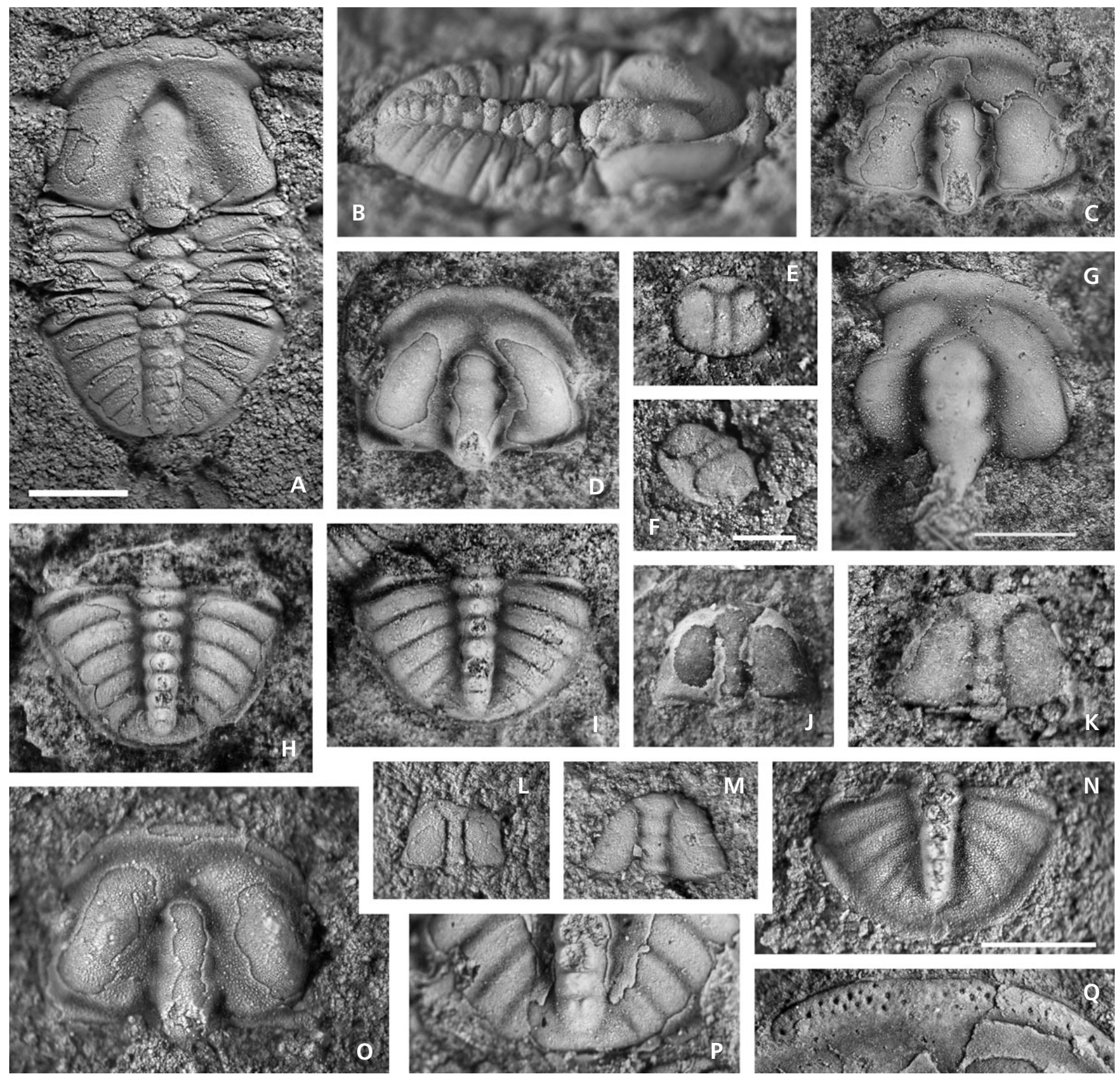

Figure 13. Neopagetina rjonsnitzkii (Lermontova, 1940), Henson Gletscher Formation. • A, B - dorsal carapace without librigenae, MGUH 29312 from GGU collection 218611, dorsal and oblique lateral views, scale bar equals $1 \mathrm{~mm}$. $\mathrm{C}$ - cranidium, partially exfoliated, MGUH 23193 from GGU collection 218610, × 15. • D - cranidium, partially exfoliated, MGUH 23192 from GGU collection 218610, $\times 20$. $\bullet$ E - protaspis tentatively assigned to Neopagetina rjonsnitzkii, MGUH 29313 from GGU collection $482331, \times 14$. $\bullet$ F - protaspis tentatively assigned to Neopagetina rjonsnitzkii, oblique anterolateral view, MGUH 29314 from GGU collection 482331, scale bar $1 \mathrm{~mm}$. $\mathrm{G}$ - cranidium, partly covered by matrix, MGUH 29315 from GGU collection 301349, scale bar $1 \mathrm{~mm}$. $\bullet$ H - pygidium, partially exfoliated, MGUH 23199 from GGU collection 218610 , $\times 13$. - I - pygidium, largely exfoliated, MGUH 23200 from GGU collection $218610, \times 16$. $\mathbf{J}$ - meraspid cranidium tentatively assigned to Neopagetina rjonsnitzkii, partly exfoliated, MGUH 29316 from GGU collection 482331, × 12. $\bullet \mathrm{K}-$ meraspid cranidium tentatively assigned to Neopagetina rjonsnitzkii, largely exfoliated, MGUH 29317 from GGU collection $482331, \times 18 . \bullet \mathrm{L}-$ meraspid cranidium tentatively assigned to Neopagetina rjonsnitzkii, internal mould with rests of test, MGUH 29318 from GGU collection $218611, \times 22 . \bullet \mathrm{M}-$ meraspid cranidium tentatively assigned to Neopagetina rjonsnitzkii, MGUH 29319 from GGU collection 218611, × 18. $\bullet \mathbf{N}$ - juvenile pygidium, MGUH 29320 from GGU collection 218611, scale bar $1 \mathrm{~mm}$; note prosopon of densely spaced granules. $\bullet$ O - immature cranidium, MGUH 29321 from GGU collection 218611 , $\times 18$; note prosopon of densely spaced granules. $\bullet P-$ pygidium, detail of posterior part of axis and adjacent pleural regions, internal mould, MGUH 29322 from GGU collection $482331, \times 8.5$. $\bullet$ Q cranidium, anterior border and adjacent regions showing subcircular scrobicules on anterior border, MGUH 29323 from GGU collection 482331, × 28. 
furrow broad (exsag.), moderately deep, with a shallow median section if the anterior border has developed a median swelling. Posterior border commencing from axial furrow as a narrow and progressively expanding lobe up to a distinct fulcrum posterior to the eye's posterior end and reduced in exsag. width by a distinct forward curvature of the posterior margin abaxially of the fulcrum. Posterior border furrow narrow, well incised. Lateral border narrow, convex.

Thorax consists of three segments. Axial ring widest at second segment, gently convex (sag. and tr.), sublenticular in dorsal view, extending laterally into the pleural furrow and slightly overhanging the adaxial position of the posterior pleural strip so that the axial furrow zigzags through the thorax. Pleurae subequal in exsag. breadth on their course, developing into ventrally deflected blunt, slightly nodular distal tips. Pleural furrows generally moderately deep, deepening from axial furrows distally, distinctly directed forward from near axial rings and swinging backward in a gentle arc to separate pleura into exsag. convex stripes.

Pygidium semicircular in outline, gently convex (tr. and sag.), length (except articulating halfring) ca 55 percent maximum width. Articulating halfring narrow and convex, (tr.), but less convex than anteriormost axial ring of the pygidium. Adjacent axial furrow well impressed throughout, narrow, almost straight. Pygidial axis highly convex (tr.), tapering rearward, composed of seven rings and a small terminal axial piece which reaches almost to the posterior border furrow, separated by a very short (sag.) connective band; width of anteriormost axial ring $\mathrm{ca} 20$ to 22 percent maximum pygidial width; axial rings 1-6 with prominent axial nodes or spines broken off in nearly all specimens; seventh axial ring occasionally with small median node. Blaker \& Peel (1997) noted that the median nodes or spines are sometimes laterally displaced.

Axial furrows narrow, well impressed anteriorly and slightly shallowing backwards. Pleural fields moderately to strongly convex (tr.), with steep descend towards lateral border furrow, divided by narrow but well incised pleural and interpleural furrows which are faint adaxially and obsolescent to absent abaxially; pleural furrows slightly less developed backwards, faintly curved and progressively more backwards directed. Anterior pleural strip of anteriormost pleural segment more prominent and convex (exsag.) than remaining pleural segments, slightly growing in exsag. width towards a distinct fulcral point with broad (tr.) and flat articulating facets, which steeply dip anterolaterally, reaching interior edge of lateral border. Adjacent pleural furrow deep, gently curved, deepest slightly adaxial of fulcral point. Lateral border relatively narrow, generally shallow, but somewhat variable in depth depending on confluence with pleural furrows. Lateral border a narrow band of fairly constant width (tr.) and fairly low con- vexity, continues into a nearly straight posterior border section posterior to the axis.

Surface of genae in young individuals covered with fine isohyptic terrace lines, anterior part of anterior border and palpebral lobes carry occasionally fine, irregular terrace lines. Some immature specimens are covered with delicate widely spaced granules. Anterior border in larger specimens with small pits concentrated to the centre portion. Individuals with larger scrobicular pits are rarely observed (Fig. 13Q).

Ontogeny. - Two samples from the Fimbuldal section yield large numbers of well preserved immature specimens of Neopagetina rjonsnitzkii which allow reconstruction of the ontogeny of this species. This ontogenetic series very much resembles that known from other eodiscoids with advanced morphological characters. Protaspids tentatively assigned to the species (Fig. 13E, F) have a slender, undivided or poorly structured rhachis that is defined anteriorly from a subtrapezoidal frontal lobe. This lobe extends laterally into a marginal ridge that stretches posteriorly up to the supposed locations of the first ocular structures at roughly half the length of the specimen. The protogenae are convex and lack any recognizable structures. One of the specimens (Fig. 13F) shows two stout thorns, one at the supposed posterior end of the supposed ocular structure, one forming a sort of genal angle. Meraspid cranidia have a slender glabella which tends to taper weakly forward up to the extended frontal lobe. The glabella is subdivided by shallow, simple, equidistant transglabellar furrows into four lobes. The lateral extension of the frontal lobes remains in a submarginal position until late meraspid stages before it develops into unambiguous eye ridges (Fig. 13L, J).

Discussion. - The Siberian cranidia from the type material (Lermontova 1940, pl. XXXV, figs 7, 7a) show a relatively distinct occipital furrow whereas the occipital spine in the specimens from Peary Land tends to develop an occipital spine which reaches forward to incorporate part of the first preoccipital glabellar lobe. In fact, the occipital spine is difficult to see in Lermontova's figures with the result that Jell (1975) excluded the occipital spine from the diagnosis of Neopagetina. Lazarenko (in Lazarenko \& Demokidov 1964, pl. I, fig. 25) showed a cranidium of Neopagetina rjonsnitzkii with the occipital ring and the preoccipital lobe both extending backward into a long spine.

In addition, the material from the Henson Gletscher Formation differs in that the border of the cephalon is generally slightly narrower (sag. and exsag.) and the pleural furrows in the pygidium are slightly less deeply impressed. These differences are partly explained by the generally smaller size and thus a prevalence of immature characters among the specimens from Peary Land, but partly also as an effect of a slightly different preservation. 
Order Corynexochida Kobayashi, 1935

Family Zacanthoididae Swinnerton, 1915

\section{Genus Zacanthopsis Resser, 1938}

Type species (by original designation). - Olenoides levis Walcott, 1886 from the Lower Cambrian Pioche Formation near Pioche, Nevada, U.S.A.

Zacanthopsis blakeri sp. nov. Figure 8A-E

1988 Zacanthopsis levis (Walcott, 1886). - Blaker \& Peel, p. 104 , figs $60.1,60.3,60.4,60.6,60.7,61.4,61.5$.

Holotype. - MGUH 23457, cranidium (Fig. 8B).

Type locality and type stratum. - Freuchen Land section (Fig. 4), Peary Land, North Greenland, Henson Gletscher Formation, horizon characterised by GGU collection 301346.

Paratypes. - Freuchen Land section, GGU collection 301346: cranidia or incomplete cranidia under MGUH 23451, MGUH 23452, MGUH 23453 (Fig. 8A), MGUH 23454 (Fig. 8C, D), MGUH 23455, and MGUH 23456; GGU collection 301348: cranidium under MGUH 29299 (Fig. 8E).

Additional material. - Freuchen Land section, in GGU collections 298547, 298553, 301340, 301346, 301349 and 315112.

Derivatio nominis. - Named after Mark Blaker, in recognition of his studies of Cambrian trilobites from Greenland.

Diagnosis. - Species of Zacanthopsis with a long occipital spine, long anterior branches of the facial suture, long palpebral lobes of $c a$ one third cephalic length separated by slight kink from the eye ridges, a fairly broad (exsag.) and concave preglabellar field and an anterior border of moderate thickness (sag.).

Description. - Cranidium subquadrate in outline. Glabella moderately convex in transverse section, gently convex in longitududinal section, sides subparallel from occipital ring forward to $\mathrm{S} 2$, diverging forward from $\mathrm{S} 2$, front gently rounded, with an occasional faint median indentation in young individuals; four pairs of lateral glabellar furrows variably impressed, S1 longest, usually well recognizable, moderately backwards swinging, reaching nearly to occipital furrow; S2 developed as shallow pits connected with axial furrows, occasionally with shallow ablique rearward process; S3 developed as shallow furrow more-or-less per- pendicular to axis or slightly forward directed or as simple lateral pits; S4 developed as lateral notches with or without shallow forward directed sulcular processes. Occipital furrow composed of moderately deep, well incised, slightly forward directed lateral portions and moderately wide, shallower, straight or faintly backward curving median section. Occipital ring broad sagittally, up to 18 percent cephalic length, extends into a long, slender, obliquely backward directed subterminal spine; lateral portions relatively slender, creating a strongly curved posterior margin, extending into moderately wide lobes connected with posterior corners of the fixigenae.

Fixigenae gently convex (exsag. and tr.), most prominent point distant from axial furrows and close to posterior third of palpebral lobe; transverse width variable, $c a 20$ to 25 percent maximum width of cranidium and $c a 65$ to 80 percent glabellar width across L1.

Palpebral lobes long, $c a$ one-third (32 to 38 percent) cephalic length in large individuals; highly convex, slightly hook-shaped with an almost straight anterior section and a moderately to strongly curved posterior half, broadest (tr.) $c a$ two-thirds length from anterior end, slightly tapering from there to the notably narrower anterior and posterior tips; posterior tips reach almost to the posterior border furrow. Palpebral furrows well defined towards palpebral lobes, narrow, moderately deep. Ocular ridges less prominent and narrower than palpebral lobes, separated from them by a faint kink and a shallow, narrow furrow confluent with palpebral furrow; directed obliquely forward from anterior ends of palpebral lobes at an angle of $c a 35$ to 45 degrees, with a faint curvature, meet axial furrows opposite S4, proceeding into a faint parafrontal band well separated from frontal lobe of the glabella.

Preglabellar field developed as a concave platform of slightly variable sagittal length, $\mathrm{ca} 15$ percent cephalic length in adult specimens; laterally progressing into concave preocular fields, which less steeply grade towards the anterior border than the preglabellar field and in some specimens show a shallow to obsolescent ridge parallel to and about one-fourth of the exsagittal length from the anterior border.

Anterior border moderately broad ( $c a 6$ to 8 percent cephalic length in large individuals, $c a 4$ to 6 percent cephalic length in small specimens) and of more-or-less equal thickness throughout, moderately to strongly convex, creating an higly convex anterior blade at the anterior margin on the ascending preglabellar and preocular fields. Anterior border furrow shallow, moderately wide, relatively poorly defined and merely a change in concavity in front of the glabella, better defined laterally towards the facial suture.

Posterior border almost straight and nearly perpendicular to axis, very narrow and blade-like adaxially, slightly swelling in exsag. width abaxially, curved ventrally and with a faint swelling at point of geniculation posterior to tip 
of palpebral lobe; proceeds as a very narrow thread-like lobe towards the occipital ring, but defined by a narrow, shallow furrow confluent with the posterior border furrow. Posterior border furrow moderately deep adaxially, continuously deeper and slightly broader (exsag.) abaxially.

Facial suture with anterior section diverging considerably from anterior tips of eyes, with straight section to almost the anterior border furrow, then curved moderately adaxially, cutting a notable portion of the anterior boder. Posterior section of facial suture strongly diverging from posterior tips of eyes, with strong and narrow curvature that creates narrowly rounded tips of the posterior border.

Surface of test smooth in general. Fixigenae covered with weakly developed caeca in a centrifugal pattern best developed abaxially or as a dense meshwork (Fig. 8E); vessels apparently originating from palpebral lobes and posterior section of eye ridges. Preglabellar field and preocular fields covered by network of variably developed caeca, usually better expressed in the anterior parts (Fig. 8A, B, E).

Discussion. - Zacanthopsis blakeri sp. nov. is morphologically similar to Z. levis (Walcott, 1886), the type species of the genus. It is distinguished from this species from the Campbell Ranch section of the Pioche Formation in having longer palpebral lobes, moderately thick anterior border, a wider, concave, preglabellar field and a longer anterior branch of the facial suture (see Hopkins \& Webster 2009, fig. 8.1, 8.2 for photos of the holotype).

The type material of Zacanthopsis virginica Resser, 1938 from the Shady Dolomite near Austinville, Virginia, is distinguished from $Z$. blakeri by a number of characters such as a more strongly curved anterior margin of the cephalon, a more strongly expanded anterior part of the glabella, more strongly developed and generally longer lateral glabellar furrows and a sagittally slightly broader anterior border. Blaker \& Peel (1997) already noted that Rasetti (1948a) assigned material from limestone boulders of the St. Lawrence River valley, Quebec, to Z. virginica and emphasized a considerable morphologic plasticity, which moved $Z$. virginica into close proximity of $Z$. levis. As a consequence, Blaker \& Peel (1997) regarded Z. virginica a a junior synonym of $Z$. levis, and this view was also shared by Hopkins \& Webster (2009). We concur with this opinion, which therefore places $Z$. blakeri in close proximity to Z. levis.

Family Oryctocephalidae Beecher, 1887

Subfamily Oryctocarinae Hupé, 1953

\section{Genus Arthricocephalus Bergeron, 1899}

Type species (by original designation). - Arthricocephalus chauveaui Bergeron, 1899 from the Lower Cambrian Ba- lang Formation north of Tongren, north-western Guizhou, Southwest China.

\section{Arthricocephalus cf. chauveaui Bergeron, 1899}

Figure 14A-C, D?, E, F

1988 Arthricocephalus chauveaui Bergeron, 1899. - Lane, Blaker \& Zhang, pl. 1, fig. 6 (only).

non 1988 Arthricocephalus chauveaui Bergeron, 1899. - Lane, Blaker \& Zhang, pl. 1, figs 1-5.

1997 Arthricocephalus chauveaui Bergeron, 1899. - Blaker \& Peel, p. 109, figs 63.1-63.3, 64.1-64.4.

non 1997 Arthricocephalus chauveaui Bergeron, 1899. - Blaker \& Peel, p. 109, fig. 62.1-62.3.

Deposited material. - Freuchen Land section (Fig. 4), GGU collection 315095: complete late meraspid carapace under MGUH 18225; four cranidia under MGUH 23469-23472; GGU collection 315096: cranidium under MGUH 23473; GGU collection 315099, pygidium under MGUH 23074. - Løndal section (Fig. 6), GGU collection 225706: cranidia under 225706.004 and MGUH 29324.

Additional material. - Løndal section (Fig. 6), GGU collection 271750 .

Discussion. - In the Freuchen Land section (Fig. 4), Arthricocephalus is restricted to a brief stratigraphic interval where it occurs together with Haliplanktos jishouensis and Lancastria cf. plana; this occurrence is bracketed by Eoagnostus roddyi, Zacanthopsis contracta and Protoryctocephalus arcticus sp. nov. In Løndal, Arthricocephalus occurs in collections with Eoagnostus roddyi, Protoryctocephalus arcticus, Ogygopsis typicalis, and Eoptychoparia pearylandica sp. nov. The material from the Henson Gletscher Formation is sparse, but was thought by Blaker \& Peel (1997) to fall well within the morphologic range of the Guizhou material. It has been suggested that the small size of the material from Greenland reflects its semi-mature nature.

The characters which distinguish the Henson Gletscher Formation specimens from Arthricocephalus chauveaui of South China are located in the pygidium. The pygidial rhachis of the Greenland specimens is slightly shorter ( $c a$ two-thirds pygidial length). The pygidial margin has an extremely narrow, wire-like border defined by a narrow border furrow and shows a wavy course. Due to the short rhachis, the posterior pleurae curve more strongly backward.

One small cranidium shows an unusual range of morphology; it has a semi-mature habit in which the glabella has a broader, loboid outline (MGUH 23472, Fig. 14D) than larger specimens with a slender meraspid-type 


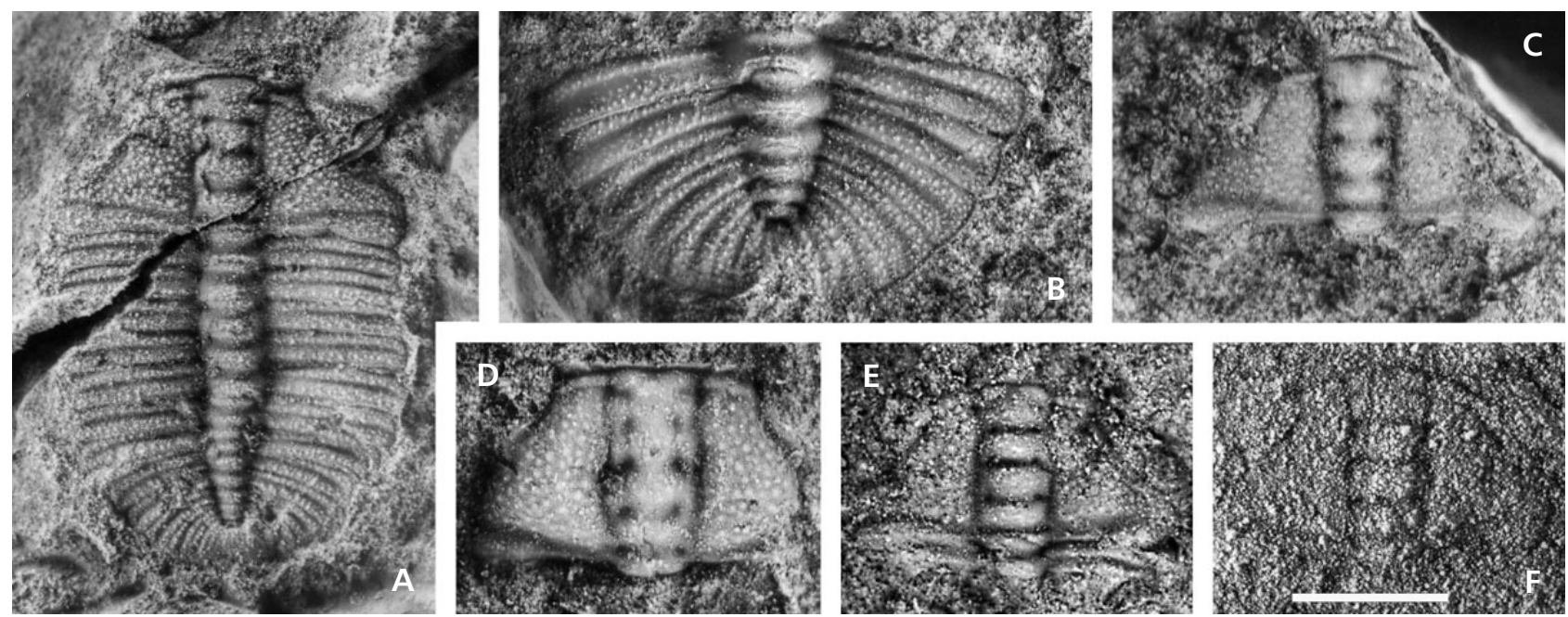

Figure 14. Arthricocephalus cf. chauveaui Bergeron, 1899, Henson Gletscher Formation. • A - meraspid degree 7 carapace, MGUH 18225 from GGU collection 315095, × 9.5. • B - pygidium, dorsal view, MGUH 23474 from GGU collection 315099, $\times 12.5$. $\mathrm{C}$ - immature cranidium, MGUH 23473 from GGU collection 315096, $\times 12.5$. D - immature cranidium tentatively assigned to Arthricocephalus cf. chauveaui, partly exfoliated, MGUH 23472 from GGU collection 315095, × 18. $\bullet$ E - meraspid cranidium with articulated anterior thoracic segment, MGUH 23471 from GGU collection 315095 , $\times 15$. F - meraspid cranidium, MGUH 29324 from GGU collection 225706, scale bar $1 \mathrm{~mm}$.

glabella. In this respect, the cranidium of Arthricocephalus cf. chauveaui resembles even meraspid cranidia of Ovatoryctocara granulata, but additional material is needed to establish the identity of this specimen.

\section{Genus Haliplanktos Blaker \& Peel, 1997}

Type species (by original designation). - Arthricocephalus (Arthricocephalites) jishouensis Zhou, 1977 from the Lower Cambrian of South China.

Discussion. - Haliplanktos jishouensis (Zhou, 1977), the type species of the genus, was described originally as Arthricocephalus (Arthricocephalites) jishouensis Zhou, 1977 (in Zhou et al. 1977). At least the holotype is from Liantaishan, Jishou County, in the northwestern Hunan Province, South China. Precise information is not presented in the original description by Zhou (in Zhou et al. 1997), but the holotype is probably from the Balang Formation. The paratype figured by Zhou et al. (1977, pl. 42, fig. 6) comes from Guangba, Guzhang County, in the northwestern Hunan Province and is probably also from the Balang Formation.

The species based on the Hunan material was selected as the type species of the (at that time) monotypic genus Haliplanktos by Blaker \& Peel (1997). Given the relatively minor differences in the characters between the taxa of the Oryctocephalidae, and the Oryctocarinae in particular, the generic separation of the species is certainly qualified. In South China, the species is only known from its type locality with certainty.
Arthricocephalus (Arthricocephalites) pulchellus Zhang \& Qian, 1980 [in Zhang et al. 1980, pl. 92, fig. 3; originally misspelled as "Arthricocephalus (Arthricocephatites) pulchellus"] is a close relative of Haliplanktos jishouensis and is transferred to Haliplanktos. It was synonymised with H. jishouensis by Blaker \& Peel (1997), but differs from that species mainly in having a broader pygidial border defined by a distinct border furrow and a slightly wider (tr.) glabella with slit-like S4 clearly connected with the dorsal furrows. Unfortunately, Zhang \& Qian (1980) gave no exact locality and stratum for Haliplanktos pulchellus. The authors only stated that it came from the border area between Hunan and Guizhou provinces and from the Palang (= Balang) Formation. It should be noted that this species is based on a specimen originally figured by Lu et al. (1963, pl. 7, fig. 7d only). In that article, the locality is said to be South China. The specimen was refigured by Lu et al. (1965, pl. 17, fig. 1 only) who stated, however, that the material is from northern Guizhou, the border area of the Hunan and Guizhou provinces, and the northern Jiangxi province.

A third species of Haliplanktos was described as Arthricocephalus taijiangensis Yin, 1978 (in Yin et al. 1978, p. 441, pl. 156, fig. 8) and later transferred to Arthricocephalus (Arthricocephalites) taijiangensis and Arthricocephalites taijiangensis, respectively (e.g. Yuan et al. 2002, pl. 30, figs 3-5). Compared with H. jishouensis, this species differs in having a slightly wider glabella in respect to the transverse cranidial width, longer and more slender palpebral lobes, and a weakly granulated surface. This species occurs in the Balang Formation of the Balang section in Taijiang county of eastern Guizhou Formation. 


\section{Haliplanktos jishouensis (Zhou, 1997)}

Figure $15 \mathrm{~A}-\mathrm{F}$

1963 Arthricocephalus chauveaui Bergeron, 1899. - Yegorova et al., p. 20, pl. 2, fig. 9 (only).

1963 Arthricocephalus chauveaui Bergeron. - Lu, pl. 7, fig. $7 \mathrm{~d}$ (non $7 \mathrm{a}-\mathrm{c})$.

1965 Arthricocephalus chauveaui Bergeron. - Lu et al., p. 108 , pl. 17, fig. 1 .

1977 Arthricocephalus (Arthricocephalites) jishouensis Zhou (sp. nov.). - Zhou et al., p. 131, pl. 42, figs 4-6.

1980 Arthricocephalus (Arthricocephatites) pulchellus [sic] Zhang \& Qian (sp. nov.). - Zhang et al., p. 276, pl. 92, fig. 3 .

1986 Arthricocephalus jishouensis Zhou, 1977. - Blaker, p. 68.

1997 Haliplanktos jishouensis (Zhou in Zhou et al., 1977). - Blaker \& Peel, p. 112, figs 64.5-64.7.

Deposited material. - Freuchen Land section (Fig. 4), GGU collection 315096: complete carapace under MGUH 23475; GGU collection 315099: nearly complete carapace under MGUH 23476; GGU collection 315095, pygidia under MGUH 23477, 29325 and 29326.

Description. - Cephalon subsemicircular in outline. Glabella more than 95 percent cephalic length, with subparallel sides in the posterior two-thirds, L1 slightly expanding backwards and occipital ring clearly wider (tr.) than L1, L4 and frontal lobe rapidly expanding so that the sides of the glabella create a concave aspect; frontal lobe with a gently curved anterior rim, reaching to the anterior border furrow; four pairs of lateral glabellar furrows developed, S1, S2, and S3 similar, short, deeply incised laterally and connected with axial furrow, connected by a well impressed, shallower transverse furrow; S4 consist of deep, slightly elongate pits isolated from the axial furrows; S1-S3 define L1-L3 as lobes of subequal size and shape, but with S2 being faintly longer (sag.). Frontal lobe expands into narrow acute projections framed by the anterolateral terminations of the axial furrows and the anterior border furrow (Fig. 15A). Occipital furrow consists of deeply incised distal portions connected by a shallower median section. Occipital ring of $\mathrm{ca} 10$ percent cephalic length, sag. and tr. gently convex, lenticular in outline with strongly curved posterior margin, expanding laterally into acute anterolaterally pointing projections that have a faint connection with the posteroproximal corners of the fixigenae; occipital node developed (Fig. 15B).

Eye lobe short, exsagittal length $\mathrm{ca} 22$ to 24 percent cephalic length, with strongly curved ocular suture, oblique to axis, located with center in transverse line with S2 to midlength of L3, palpebral furrow shallow; eye ridge gently curved, low, directed inward and forward to axial furrow opposite $\mathrm{S} 4$, defined by moderately distinct furrow close to the anterior border furrow. Fixigenae distinctly convex (tr.), subtriangular in outline, uniformly vaulted, extended into large posterolateral projections.

Anterior border very narrow (sag.) and thread-like in front of the glabella, slightly wider anterior to the genal fields. Anterior border furrow a very narrow (sag. and exsag.) incision. Genal field forms a slightly convex, quite narrow oblique area. Posterior border convex, narrow proximally, broadening distally from a very narrow section at axial furrows to a maximum close to the genal angle. Posterior border furrow well-defined, moderately broad and moderately deep, more-or-less straight in the proximal portion, with a slight rearward swing distally close to the genal angles. Anterior branch of suture curves forward and slightly inward when reaching anterior border furrow. Posterior branch of the suture directed obliquely outward, rapidly swinging backward to create large posterolateral projections.

Librigena with narrow (tr.), steeply to almost perpendicularly rising ocular platform; lateral border narrow; lateral border furrow well impressed anteriorly, progressively shallower and changing into merely a change in convexity at the posterior rim of the librigena.

Thorax of six segments. Axial rings slightly tapering rearward. Axial ring gently convex (sag. and tr.), with faint anterolateral inflation and a deep pit of articulating process in the axial furrow. Pleurae subequal in exsag. breadth along their course, with a faint geniculation about midlength and with large ventrally deflected facet, terminating in gently rounded to subtriangular tips with a tiny stout spine. Pleural furrows moderately deep, deepest near axial furrow, slightly backward directed from there, with a slight curvature, fading near pleural tips.

Pygidium with maximum transverse width across anterolateral corners. Axis with ca 25 percent maximum pygidial width across first axial ring and of $c a 75$ percent pygidial length (except for articulating halfring); consisting of five axial rings and a terminal axial piece. Axial rings distinctly convex (sag. and exsag.) with lateral swollen portions, separated by fairly broad (sag. and exsag.) furrows. Articulating halfring crescentic, sag. moderately wide, transversely convex and well raised from articulating furrow. Behind the rhachis is a short (sag.) convex area with a faint to moderately clear swelling creating a faint kink in the course of the posterior margin and a slightly upturned short section of the posterior margin in posterior view. Pleural areas moderately convex (tr.), steeply sloping towards border furrow, defined by five well impressed, but progressively shallower pleural furrows and with faint interpleural furrows, which are well developed only close to the lateral border furrow. Posterior pleurae and posterior area with shallower inconspicuous furrows. Pygidial lateral and posterior border narrow, subequal in breadth 

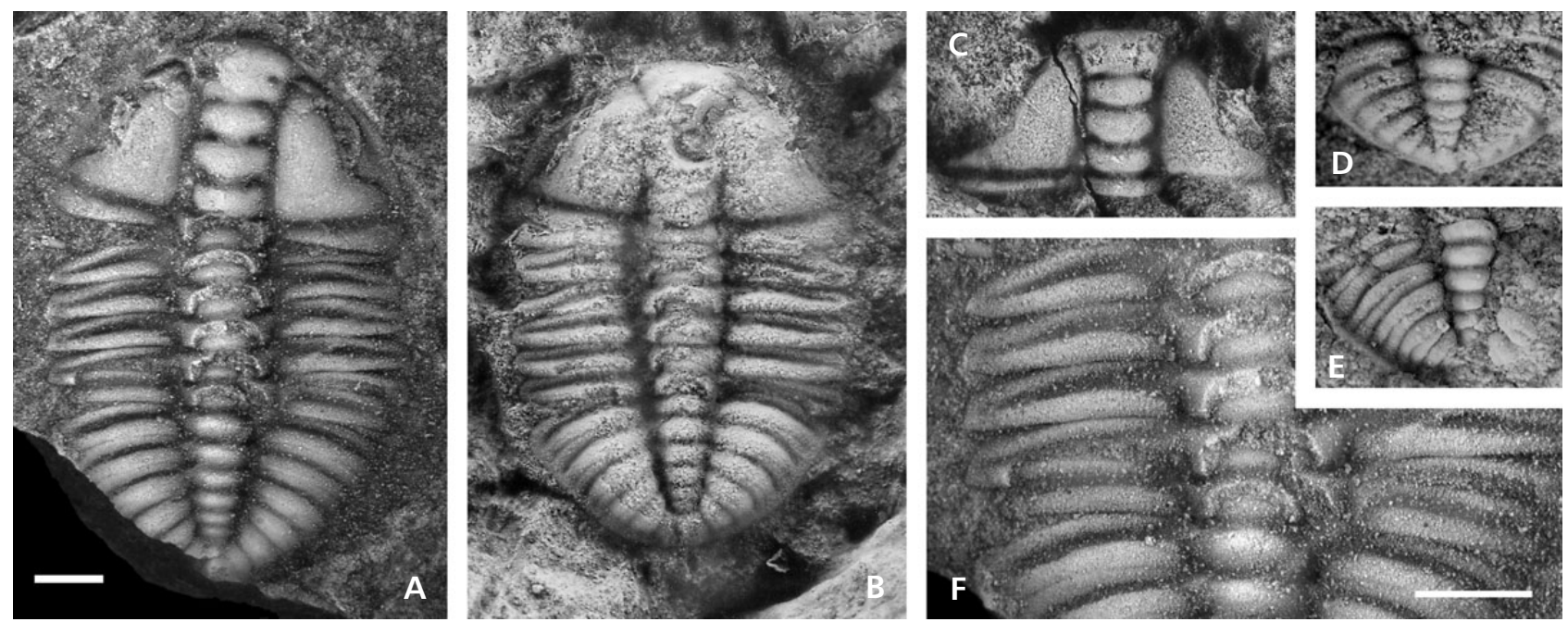

Figure 15. Haliplanktos jishouensis (Zhou, 1997), Henson Gletscher Formation. • A, F - nearly complete holaspid carapace, MGUH 23476 from GGU collection 315099 . A - dorsal view of entire specimen, $\times 8.5$. F - detail of posterior thorax and attached pygidium; note change in transverse convexity from thorax to pygidium; $\times 15.5$. $\bullet$ B - nearly complete carapace, largely exfoliated and corroded, MGUH 23475 from GGU collection $315096, \times 11$. - C - cranidium, MGUH 23477 from GGU collection 315095, $\times 9$. $\bullet$ D - immature pygidium, MGUH 29325 from GGU collection $315095, \times 18$. $\bullet$ E - partial immature pygidium, MGUH 29326 from GGU collection 315095, × 12.5 .

throughout except for slightly wider section near anterolateral corners, defined by a shallow to obsolescent border furrow which is merely a change in convexity.

Entire carapace smooth or with small and indistinct pores.

\section{Discussion. - See under genus Haliplanktos.}

Stratigraphic occurrence. - Haliplanktos jishouensis is a fairly rare species in the Henson Gletscher Formation, only known so far from a brief stratigraphic interval in the Freuchen Land section (Fig. 4). The species co-occurs with Arthricocephalus cf. chauveaui and Lancastria cf. plana, bracketed by the occurrences of Eoagnostus roddyi, Ogygopsis typicalis, and Protoryctocephalus arcticus sp. nov.

\section{Genus Ovatoryctocara Chernysheva, 1962}

Type species (by original designation). - Oryctocara ovata Chernysheva, 1960 from the Middle Cambrian Amgan Stage of the Siberian Platform, Russia.

Discussion. - For a long time, the genus Ovatoryctocara has been regarded as being composed of three species: Ovatoryctocara ovata Chernysheva, 1962 and O. granulata Chernysheva, 1962, which are fairly frequent in lowermost Middle Cambrian strata of the Siberian Platform, and a third less frequent species, O. angusta Chernysheva, 1962 with the subspecies O. angusta snegirevae (Suvorova, 1964). All three species are quite easily distinguished. Recently, Shabanov \& Korovnikov (in Shabanov et al. 2008b) introduced the new species $O$. doliiformis from the Siberian Platform, while Shabanov et al. (2008a, pl. 8, figs $3,4,10$ ) figured another, not formally introduced species of Ovatoryctocara. These species and subspecies are characterized in detail in an article by Naimark et al. (this volume). In addition, Yuan et al. (2009) introduced the new species $O$. yaxiensis from South China.

Careful examination of the published specimens, and particularly the rich material from the Henson Gletscher Formation of North Greenland, reveals considerable differences in material that has been assigned to Ovatoryctocara granulata or, based on these differences, has been described as Ovatoryctocara sp. A by Blaker \& Peel (1997).

The general assumption that Ovatoryctocara granulata is an easily determinable species, with an enormous morphologic plasticity that is recognizable even from distorted specimens, is incorrect. Dorsoventral compaction creates the impression that the glabella and particularly the pygidial axis are variable in transverse width. In addition, precise determination of immature cranidia is hindered by the complicated ontogenetic development that helps to produce convergent morphologies of apparently different species during different stages of maturity. The discussion presented herein is mainly based on the specimens of Ovatoryctocara collected in the Henson Gletscher Formation which display a reasonable, but still limited, range of preservation features. Close scrutiny of all available material is needed to establish the full spectrum of morphological variation within and between the species.

The typical Siberian material of Ovatoryctocara granulata has a moderately wide glabella with only a slight 
median expansion (tr.) and moderately broad fixigenae; the distance between the palpebral furrows and the axial furrows is clearly wider than half maximum glabellar width. Its glabellar shape shows some variation, but remains relatively slender and has a tendency towards a slightly expanding frontal portion anterior to S3. The rearward movement of the eyes and their less oblique alignment during ontogeny serves to produce a superficial similarity of immature cranidia with adult cranidia of $O$. yaxiensis.

The pygidium of $O$. granulata is more characteristic than the cranidium, having a "semi elliptical" outline with a ratio length: width of $c a 0.8$. It is primarily characterized in semi-mature to mature individuals by a slender rhachis with 7 axial rings, plus an articulating half ring of similar appearance and a terminal axial piece. The length of the rhachis is sometimes more than 90 percent of the pygidial length and generally lies at about 80 percent. Its length, however, is often misinterpreted when the rearmost part of the pygidium is covered by matrix. The pleural areas are defined by sharp pleural furrows and distinct, slightly shallower interpleural furrows. Details of the postaxial area are usually difficult to recognize and consists of shallow subradial furrows. Mineralization below the shield, possibly as a result of diagenetic modification of fecal products, may serve to produce a bulbous structure in a number of specimens of $O$. granulata as well as $O$. yaxiensis (Fig. 18U).

The surface of the test is covered by irregularly spaced granules of different diameters on the cranidium, with smaller granules of more uniform size on the pygidium. These granules are arranged in slightly irregular rows on the crests of the pleurae and as unordered transverse rows on the axial rings.

The species from South China usually determined as Ovatoryctocara granulata has narrow fixigena, with the distance between palpebral furrows and glabella is less than half the maximum glabellar width (e.g. Yuan et al. 2009, fig. 2a, b). However, pygidia usually have only 6 axial rings plus a terminal axial piece. In addition, the relative length of the pygidial rhachis is shorter than in the Siberian specimens, and the glabella shows a distinct median expansion (e.g. Yuan et al. 2002, pl. 29, figs 4, 5).

Yuan et al. (2009) introduced a new species of Ovatoryctocara under the name Ovatoryctocara yaxiensis from the lower part of the Aoxi Formation at Yaxi Village, eastern Tongren, northeastern Guizhou. Although a formal diagnosis is lacking in the publication, the text refers to a trapezoidal cranidium, a club-shaped glabella which is expanded medially and has four pairs of lateral furrows, of which $\mathrm{S} 1-\mathrm{S} 3$ are triangular pits and S4 is shallow. The fixigenae are said to be narrower (tr.) than those in O. granulata, the palpebral lobe shorter and situated a little anterior to the midway of facial suture across the fixigenae. According to Yuan et al. (2009, p. 216), the "posterolateral area" is wider (exsag.) than in $O$. granulata (despite the fact that some of the Siberian cranidia have very broad postocular areas; see Naimark et al., this volume). Yuan et al. (2009) emphasized that the semi elliptical pygidium has seven axial rings and a terminal piece, while seven pairs of marginal tips giving a saw tooth-like shape of the lateral margins in dorsal view. The pleural region is said to have seven pairs of deep pleural furrows and distinct, narrow, interpleural furrows. The exoskeleton has a few coarser and fine granules. Yuan et al. (2009) further stated that the main differences from $O$. granulata were the club-shaped glabella with triangular glabellar furrows/pits (S1-S3), shorter palpebral lobes just anterior of the midlength, longer posterolateral area (exsag.), and the semi elliptical pygidium with eight pairs of marginal tips giving a saw tooth-like shape of the lateral margins in dorsal view.

Yuan et al. (2009, figs 4a-e) only figured two cranidia and three pygidia assigned to Ovatoryctocara yaxiensis and these, with the exception of the pygidium (fig. 4d), had been figured previously as Ovatoryctocara granulata (Yuan et al. 2002, pl. 31, figs 10-13). In the two cranidia, only the right palpebral lobe in the specimen on fig. $4 \mathrm{e}$ clearly shows the diagnostic position of the palpebral lobe, and this position is the same or slightly posterior compared with that in cranidia of $O$. granulata. In contrast to the description, the pygidia of the type material (Yuan et al. 2009, figs 4b-d) and the illustrative drawing, all show up to six (not seven) axial rings plus the terminal axial piece. In addition, it should also be noted that the specimen illustrated in fig. 4a, which is chosen at the holotype, has granules which are surprisingly coarse and much larger than those in the cranidium on fig. $4 \mathrm{e}$ (both described as having the same magnification).

In the Henson Gletscher Formation, three different morphotypes can be recognized. One is readily determinable as Ovatoryctocara granulata. Its pygidia have a relatively slender, long axis with up to seven axial rings and a terminal axial piece. Other pygidia in the same strata and with similar size are characterized by a broader, relatively short axis with normally no more than six axial rings plus a terminal axial piece. They are clearly not an ontogenetic stage of $O$. granulata and can be determined as O. yaxiensis. In fact, in contrast to the original diagnosis, the newly introduced species is best recognized by the differences in its pygidium. As demonstrated by the type material of Yuan et al. (2009), a useful character to distinguish Ovatoryctocara yaxiensis from the Siberian material of O. granulata is the shorter and slightly wider pygidial axis, and the tendency to develop a slightly upturned postaxial region which is slightly elevated above the adjacent posterolateral pleural areas. If a specimen is more-or-less uncompacted and the posterior margin is still partially covered by matrix, these pygidia tend to have a subacute outline. Differences in the cephalon are mostly insignificant in 
juvenile and small adult specimens. However, the broader, medially expanded glabella in large individuals may serve as a diagnostic character for $O$. yaxiensis.

In summary, Yuan et al. (2009) were correct in recognizing a second species of Ovatoryctocara in the sections of South China. However, their chosen holotype is unsuitable to characterize this new species, and the characters described by Yuan et al. (2009) appear to be insufficient to define $O$. yaxiensis. We also conclude that a slightly different type of preservation accounts for the more pronounced overall convexity in the Aoxi specimens, so that the pygidia appear narrower, with the ends of the pleurae often sticking into the matrix. This uncertainty may result from the limited amount of material in the Aoxi Formation (only two cranidia and three pygidia known); the Henson Gletscher material provides a better key to the morphology of the species. In addition, it can be noted that most of the specimens of Ovatoryctocara described from South China have the characters of $O$. yaxiensis, and it appears to be uncertain how often the true $O$. granulata occurs on the Yangtze Platform.

Ovatoryctocara yaxiensis and $O$. granulata co-occur in the Henson Gletscher Formation, undermining the conclusion of Yuan et al. (2009) that $O$. yaxiensis is a precursor of $O$. granulata and that the $O$. yaxiensis assemblage of the lower Aoxi Formation "may be older than the B. holopygus-O. granulata Zone in the lower part of the Kaili Formation" (Yuan et al. 2009, p. 218).

\section{Ovatoryctocara granulata Chernysheva, 1962}

Figures 16A-K, L?, M-O, P?, Q-S, T?, U-Z, A'-D'

1962 Oryctocara (Ovatoryctocara) granulata sp. nov.; Chernysheva, p. 40, pl. V, figs 6-8.

?1971 Oryctocara (Ovatoryctocara) sp. - Chernysheva in Chernysheva et al., p. 140, pl. 13, figs 8, 9.

1972 Oryctocara (Ovatoryctocara) granulata N. Tchernysheva, 1962. - Savitsky et al., p. 77, pl. 16, fig. 10.

1976 Oryctocara (Ovatoryctocara) granulata N. Tchernysheva, 1962. - Yegorova et al., p. 96, pl. 43, figs $15-17$.

1997 Ovatoryctocara sp. A. - Blaker \& Peel, p. 114, figs 65.3, 66.1, ?66.3 (only).

?1997 Ovatoryctocara spp. - Yuan et al., pl. III, fig. 11 (only).

non 1997 Ovatoryctocara spp. - Yuan et al., pl. III, fig. 12.

2000 Oryctocara (Ovatoryctocara) granulata Tchernysheva, 1962. - Pegel, p. 1011, figs 10-13.

2001 Ovatoryctocara granulata Tchernysheva, 1962. Yuan et al., pl. 1, fig. 5.

2001 Ovatoryctocara granulata Tchernysheva, 1962. Zhao et al., pl. 1, figs 8, 9.

non 2002 Ovatoryctocara granulata Tchernysheva, 1962. -
Yuan et al., pp. 125, 252, pl. 29, figs 4, 5, pl. 31, figs $10-13$ (= O. yaxiensis).

?2002 Ovatoryctocara granulata Tchernysheva, 1962. Yuan et al., pp. 125, 252, pl. 31, fig. 8 .

2003 Ovatoryctocara granulata Tchernysheva, 1962. Fletcher, p. 98, fig. 2c-f.

2004 Ovatoryctocara granulata Chernysheva, 1962. Zhao et al., p. 1035.

2005 Ovatoryctocara granulata Chernysheva, 1962. - Geyer, p. 85 , fig. 2.1-2.3.

2006 Ovatoryctocara granulata Tchernysheva, 1962. Fletcher, pl. 27, figs 46, 47.

2007 Ovatoryctocara granulata Tchernysheva, 1962. Zhao et al., fig. 4I

?2007 Ovatoryctocara granulata Tchernysheva, 1962. Yuan et al., p. 62, fig. 4.I.

?2008 Ovatoryctocara granulata Chernysheva, 1962. Zhao et al., p. 1550, fig. 3e.

2008a Ovatoryctocara granulata Tchernysheva, 1962. Shabanov et al., pl. 2, figs 1-3, ?4, pl. 2, fig. 12, pl. 8, figs $1-2,95,6-9$, pl. 10 , fig. 8.

non 2008a Ovatoryctocara granulata Tchernysheva, 1962. Shabanov et al., pl. 10, fig. 9.

2008b Ovatoryctocara granulata Tchernysheva, 1962. Shabanov et al., pp. 85, 86, pl. 1, figs 1-4, pl. 2, fig. 12, pl. 7, figs 1, 2, 5-9, pl. 9, figs 8, 9 .

2009 Ovatoryctocara granulata Tchernysheva, 1962. Yuan et al., pp. 213, 216, figs 2a, b, 3a-g.

Type material. - From the middle reaches of the Olenek River, Udzhi River Basin, Siberian Platform, deposited in the Central Geological Museum, St. Petersburg, coll. No. $46 / 8194$.

Deposited material from the Henson Gletscher Formation. - From Fimbuldal section (Fig. 5), GGU collection 218611: cranidia under MGUH 29333, 29340, 29342 and 29347; from GGU collection 218682: pygidium under MGUH 29343; from GGU collection 482322: two cranidia under MGUH 29328 and 29329; from GGU collection 482328: dorsal carapace under MGUH 29330, seven cranidia under MGUH 29334, 29335, 29337, 29338 and 29341, six pygidia under MGUH 29345, 29349, 29350, 29351, 29353 and 29355; from GGU collection 482331: two cranidia under MGUH 29332 and 29336, two pygidia under MGUH 29352 and 29354; from GGU collection 482332: pygidium under MGUH 29348, protaspis under MGUH 29346; from GGU collection 482333: two cranidia under MGUH 29337 and 29339.

Additional material. - Abundant material from GGU collections 482330, 218610, 218611, 482331, 482321, 482324, 482322, 482328, 482332, 482333, 482329, and 482323. 
Description of the adult morphology. - Cranidium with broadly extending posterolateral projections of the fixigenae; maximum length about half maximum width or slightly less.

Glabella slightly lyriform with maximum width (tr.) across S2, frontal part expanding frontal to about the maximum glabellar width (tr.) of (in adult specimens) ca 40-50 percent cranidial width across posterior ends of eye lobes; divided by a nearly straight to faintly backwardly curved occipital furrow and the pits S1-S4; S0 and S1-S4 more-or-less equally spaced from each other, the anterior glabellar lobe slightly longer (sag. and exsag.) than L0-L4; the pits of S1-S3 situated well distant from the axial furrow, the S1, S2 and S3 pairs connected by a faint furrow, connected with the axial furrows by slightly better impressed furrows; S4 a pair of slightly shallower and smaller pits than S1-S3, situated close to the axial furrow. Faint longitudinal furrows may be present from $\mathrm{S} 1$ through $\mathrm{S} 3$ in moderately large individuals, but dorsoventral compaction regularly enhances their depth and creates conspicuous furrows across the pits of S0 through S4. Frontal lobe in younger individuals with the tendency to develop a weak sagittal median sulcus. Occipital furrow shallow to moderately well developed medially, with short lateral sections rising from pit-like depressions. Occipital ring with slightly curved posterior margin, with a faint median node in a relatively anterior location.

Eye lobe moderately long (exsag. of up to $c a 25$ percent cephalic length), slightly curved, somewhat to conspicuously oblique to axis, anterior end in transverse line with L4, posterior end in transverse line with S1; palpebral lobe narrow, rises steeply from shallow and narrow palpebral furrow and proceeds into shallow and often inconspicuous eye ridge directed inward and forward to axial furrow opposite L5 directly in front of S4. Margin between palpebral lobe and eye ridge marked by a shallow depression.
Fixigenae narrow to moderately wide, usually ca 40-45 percent maximum glabellar width. Posterior branch of the suture directed straight outward from the posterior ends of the visual surface and almost straight for short distance, then rapidly swinging backward to create large posterolateral projections.

Anterior border very narrow (sag.) and thread-like in front of the glabella, slightly wider anterior to the genal fields. Anterior border furrow a very narrow (sag. and exsag.) incision. Genal field forms a slightly convex, quite narrow oblique area. Posterior border narrow to moderately wide (exsag.), convex, rapidly expanding from a very narrow section at axial furrows (Fig. 16F) and to a maximum posterior to the posterior end of the eyes. Posterior border furrow well-defined, narrow, moderately deep, more-or-less straight in the proximal portion, with a rearward swing starting posterior to the posterior end of the eyes. Anterior branch of suture curves forward and slightly inward when reaching anterior border furrow.

Thorax composed of four segments. Axial ring of anterior segment with wide (sag. and exsag.) rearward swinging articulating furrow with shallow apodemal pit distally. Axial ring with faint lateral inflation and a deep pit of articulating process in the axial furrow. Pleurae faintly backward directed, minutely growing in breadth distally up to the base of the short genal spine. Pleural furrows moderately deep, curve slightly back from the axial furrow, then straight and directed faintly obliquely across the pleura. Second to fourth segments similar, but with a less backward swinging articulating furrow and with slightly more rearward directed pleurae.

Pygidium in adults with 7 (rarely 6 or 8 ) axial rings and a minute terminal axial piece, axis (except for articulating halfring) variably of $c a 78$ to 87 , rarely 90 percent pygidial length. Posterior to the rhachis is a short (sag.) convex area with a faint swelling. Posterior margin equally curved,

Figure 16. Ovatoryctocara granulata Chernysheva, 1962, Henson Gletscher Formation. • A - cranidium, MGUH 29327 from GGU collection 482333. - B - cranidium, MGUH 29328 from GGU collection 482322. C - cranidium, MGUH 29329 from GGU collection 482322 , and undetermined protaspis. - D - dorsal carapace of immature individual, MGUH 29330 from GGU collection 482328. • E - dorsal carapace of immature individual, MGUH 29331 from GGU collection 482325. • F - cranidium, MGUH 29332 from GGU collection 482331. • G - juvenile cranidium, MGUH 29333 from GGU collection 218611. • H - immature cranidium, MGUH 29334 from GGU collection 482328. • I - immature cranidium, MGUH 29335 from GGU collection 482328. • J - cranidial fragment, MGUH 29336 from GGU collection 482331 • K - immature cranidium, MGUH 29337 from GGU collection 482328. - L - meraspid cranidium tentatively assigned to Ovatoryctocara granulata, MGUH 29338 from GGU collection 482328 . $M$ - immature cranidium with articulated anterior thoracic segment, MGUH 29339 from GGU collection 482333. • N - immature cranidium, MGUH 29340 from GGU collection 218611; note bulbous anterolateral corners of glabellar frontal lobe. • O - immature cranidium, MGUH 29341 from GGU collection 482328, with short oblique palpebral lobes in anterior position. • P - juvenile cranidium tentatively assigned to Ovatoryctocara granulata, MGUH 29342 from GGU collection 218611. • Q, V - pygidium, MGUH 29343 from GGU collection 218682, dorsal and oblique posterior views. • R - cranidium, MGUH 29344 from GGU collection 482328. • S - pygidium, MGUH 29345 from GGU 482328. • T - protaspis tentatively assigned to Ovatoryctocara granulata, MGUH 29346 from GGU collection 482332; note lateral spine. • U - meraspid cranidium, MGUH 29347 from GGU collection 218611 . $•$ W - immature pygidium, MGUH 29348 from GGU collection 482332. • X - immature pygidium, MGUH 29349 from GGU collection 482328. • Y - pygidium, MGUH 29350 from GGU collection 482328. • Z - meraspid pygidium with articulated thoracic segments, MGUH 29351 from GGU collection 482328. • A' - pygidium, MGUH 29352 from GGU collection 482331. • B' - pygidium, MGUH 29353 from GGU collection 482328. • C' - pygidium, MGUH 29354 from GGU collection 482331, overlain by meraspid ptychoparioid trilobite. • D' - immature pygidium, MGUH 29355 from GGU collection 482328. Scale bars $1 \mathrm{~mm}$. 
Gerd Geyer \& John S. Peel • Cambrian Series 2-3 boundary in North Greenland
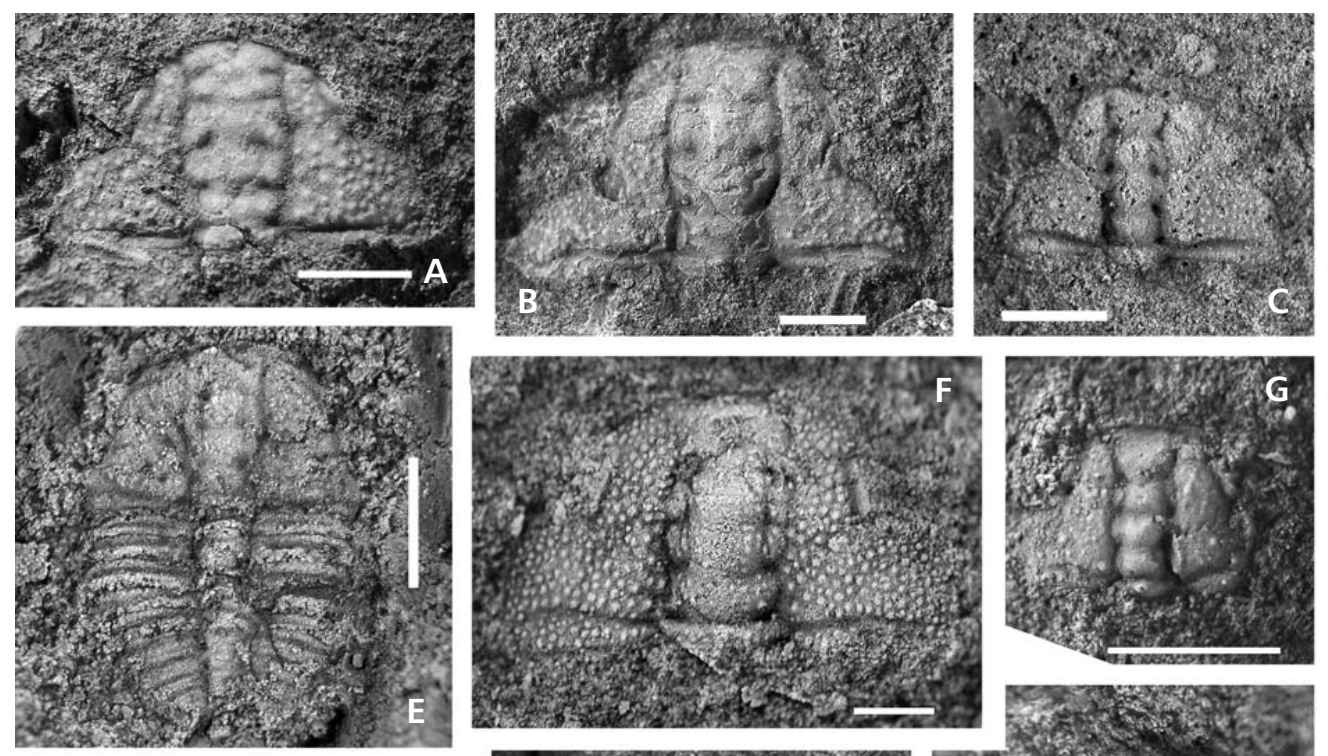

\section{0}
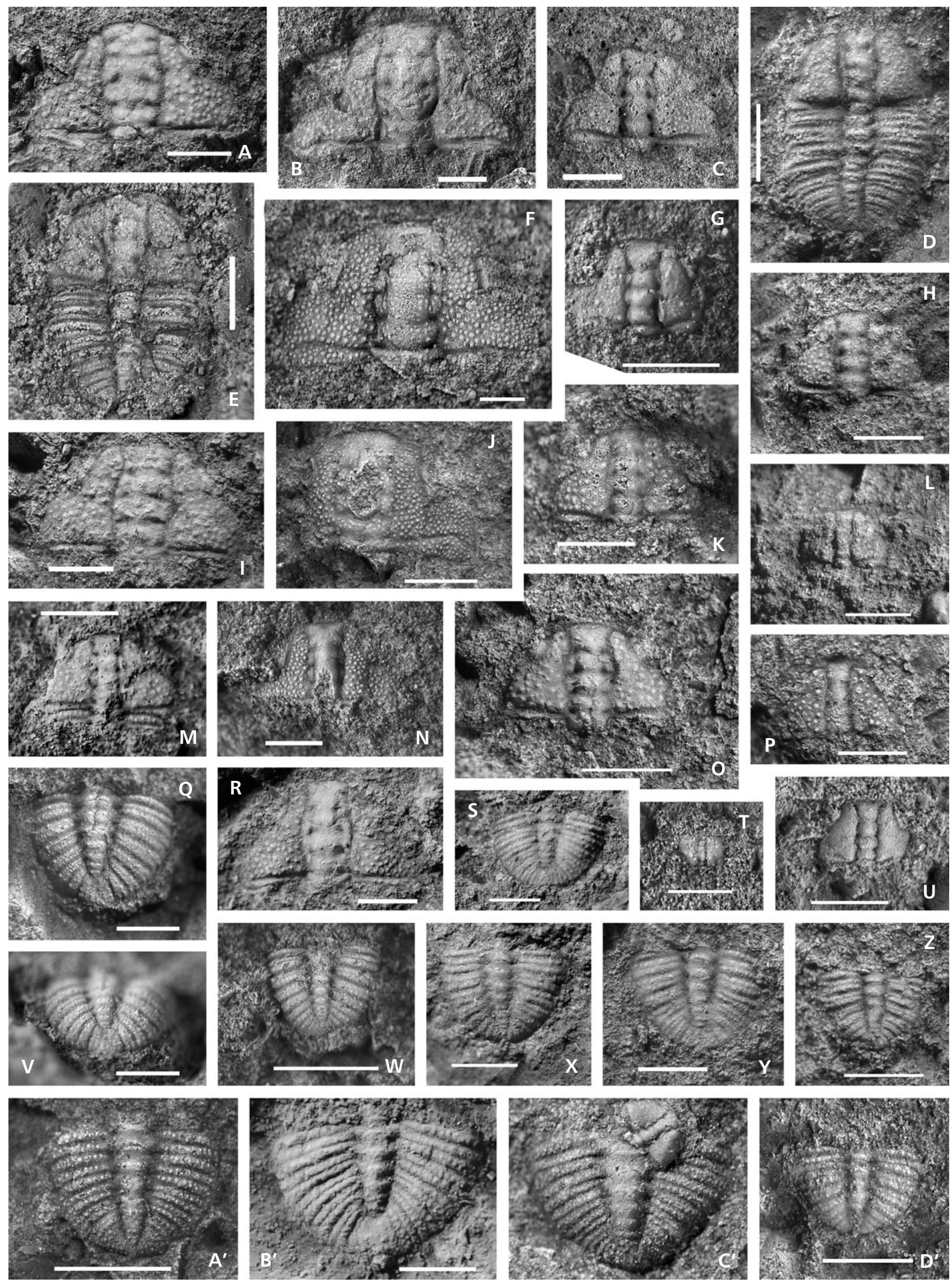
rarely with a faint kink in the course and a slightly upturned short section of the posterior margin in posterior view, when a swelling is developed. Axial rings distinctly convex (sag. and exsag.) with lateral swollen portions, separated by fairly broad (sag. and exsag.) furrows. Axial ring of anterior segment of $c a 25$ percent pygidial width. Articulating halfring crescentic, sag. moderately wide, transversely convex and well raised from articulating furrow. Pleural areas convex. Pleurae 1-5 progressively backward directed, medially divided by well impressed, slightly backward curved pleural furrows. Interpleural furrows less well developed than pleural furrows, slightly fading rearward, shallow to obsolescent and shorter between the posteriormost pleurae. Posterior pleurae and posterior area with shallower, inconspicuous furrows.

Entire carapace (except for furrows and palpebral lobes) covered by generally moderately coarse, more-orless equally spaced granules. However, the size of the granules varies considerably among individuals (Fig. 16A, F, J) independent from size and habitat. Granules on thoracic and particularly pygidial pleurae tend to be arranged in relatively ordered pair-wise rows; granules on pygidial axial ring dominated by distinct pairs of larger granules.

Ontogeny. - The morphological changes during ontogeny parallel those known from other oryctocephalids. They are most striking in the shape of the glabella and its lateral furrows, the position, size, and orientation of the eyes and, as a result, the palpebral lobes, eye-ridges and the posterior branch of the facial suture.

Early meraspids have a slender, roughly parallel-sided glabella with only a slight constriction at about S3. The glabellar front is subtruncate and composed mainly of a pair of very small, more or less bulbous lobes. During further development, the frontal part of the glabella starts to grow more quickly so that the frontal part of the glabella extends markedly (tr.) and is clearly wider than the posterior part of the glabella in middle to late meraspid individuals. A distinct broadening of the lobes centered around S2 has its onset in the late meraspid to early holaspid periods. The broadening moves forward until the typical pyriform shape is developed.

The synchronous development of the lateral glabellar furrows is combined with the shape of the glabella. Simple transverse grooves are developed in the parallel-sided glabella of the early and middle meraspid stages. A pair of longitudinal furrows develops with the onset of the broadening around S2; these furrows are enhanced in early holaspids and modified to form weakly developed pits which finally tend to assume a subtriangular outline.

The anterior border is generally developed as a narrow, thread-like band. It is barely visible in early meraspids, but has a more or less equally curved course in early to middle meraspids. With the enlargement of the frontal part of the glabella, the sagittal portion of the anterior border is pushed forward so that the anterior cephalic margin describes a slight curvature around the glabellar front; this condition persists until a gerontic exsagittal broadening of the preocular areas is attained.

The eyes develop in a conspicuously anterolateral position in the earliest meraspids. The palpebral lobes are rarely preserved in these small specimens, but seem to be quite narrow at first and sit relatively obliquely with respect to the axis. Palpebral lobes grow rapidly in width and length, and less rapidly move backward with growing size, at the same time turning into a less oblique direction. The eye ridges, first visible as relatively broad (exsag.) transverse and smooth lobes directly posterior to the anterior border furrow, move slightly backward during meraspid ontogeny, while swinging more and more backward towards the anterior ends of the palpebral lobes. Their relative exsagittal width diminishes and they are progressively covered with granules.

In early meraspids, the posterior branch of the facial suture makes up most of the lateral margin of the cranidium with a distinct rearward curvature from the posterior end of the eyes. With the posterior movement of the eyes and palpebral lobes, this part of the suture develops into an increasingly more laterally directed margin of the cranidium, finally with a section next to the posterior end of the eyes that is directed almost normal to the axis for short distance.

Changes in the pygidium during ontogeny mainly affect the number of axial rings and the relative width of the pleurae. The smallest pygidium which can be determined as Ovatoryctocara granulata has five axial rings plus a terminal axial piece; its size suggests that specimens with fewer axial rings would be difficult to identify. The axis in the smallest meraspids is slender and broadens considerably in respect to the total width by means of differential growth rates. Allometric growth is also responsible for the rearward movement of the palpebral lobes.

Discussion. - The Siberian material of Ovatoryctocara granulata indicates that the morphological plasticity of the species is considerable, particularly in the shape of the glabella and the expression of the anterior glabellar furrows. Part of this variability is a result of compaction in shaly matrix, but differences in the distance between glabella and palpebral lobes or in the degree of the expansion of the anterior glabellar lobe are certainly not effects of a differential compaction.

It is particularly noteworthy that the published pygidia which are not obviously flattened all show a relatively pronounced convexity, with wide pleural fields that distinctly slope towards the margin, and with a moderately slender axis of $c a 26$ to 29 percent of the pygidial width across the broadest part near the axial ring. The 
length:width ratio of undeformed material is in the order of 0.60 to 0.65 . Compaction creates a wide pygidium in which the axis is only ca 23 to 25 percent of the pygidial width. However, strong compaction often causes the axis to crack along the midline and the resulting halves may slip so that the axis measures more than 31 to 34 percent of the pygidial maximum width.

The axis is $\mathrm{ca} 80$ to 85 percent of the pygidial length, but it is shorter in flattened specimens. By contrast, the glabella is usually slender, often with subparallel sides with a slightly narrower (tr.) anterior section anterior to $\mathrm{S} 3$, but individuals with distinctly curved axial furrows are known. The anterior border is narrow (sag. and exsag.), nearly wire-like and prominent; it describes a uniform curve.

The largest of the complete Siberian specimens are usually 4 to $5 \mathrm{~mm}$ long. Yegorova et al. (1976, pl. 43, fig. 15) figured an almost complete carapace nearly $6.5 \mathrm{~mm}$ long which differs in possessing a slightly "extended" pygidium (ratio length : width $\mathrm{ca}$ 0.85). The short axis, in particular, suggests that these large specimens from the Amyday River region represent a different, not yet formally described species of Ovatoryctocara.

Sparse and very small specimens possibly assignable to Ovatoryctocara granulata were described by Chernysheva (in Chernysheva et al. 1971) from the eastern part of the Eldakh in the Azytal range in the Batenev Ridge of the Sayan-Altay Foldbelt. The specimens come from the lower part of the Eldakh "horizon" which correlates with the lower Amgan.

Ovatoryctocara yaxiensis appears to be present in the Siberian material, but has not yet been formally designated.

Note on the mode of life. - Ovatoryctocara granulata and O. yaxiensis are among the most frequent trilobites in the middle part of the Henson Gletscher Formation in the Fimbuldal section (Fig. 5). More than 400 specimens have been examined from this section, including individuals at nearly all growth stages, from supposed protaspids and degree 0 meraspids to holaspid phases. Depending on the various sample horizons, up to 10 percent of the specimens are complete, or nearly complete carapaces in various stages of disaggregation. Librigenae, however, appear to be generally absent. Based on this relative completeness of the moulds, these (semicomplete) specimens are interpreted as intact exuviae. Hence, the specimens in the black shale/limestone facies of the Henson Gletscher Formation appear to have undergone only limited transport prior to burial. These conditions also advocate that Ovatoryctocara had a benthic mode of life after the onset of the meraspid phase, despite the distinct black shale-type substrate which suggests an oxygen-depleted environment at the sea-bottom.
Ovatoryctocara yaxiensis

Yuan, Zhao, Peng, Zhu \& Lin, 2009

Figures 17A-W

1997 Ovatoryctocara sp. A. - Blaker \& Peel, p. 114, figs 65.1, 65.2, 66.2, 67.5 (only).

2002 Ovatoryctocara granulata Tchernysheva, 1962. Yuan et al., pp. 125, 252, pl. 29, figs 4, 5, pl. 31, figs 10-13.

2009 Ovatoryctocara yaxiensis sp. nov. - Yuan et al., pp. 213, 214, 216, 217, 218, 219, figs 4a-e, 4aa, 4bb.

Type material. - From Aoxi Formation, Yaxi, near Shizhu Town, Tongren County, eastern Guizhou, South China; housed in the Nanjing Institute of Geology and Palaeontology, Academia Sinica, Nanjing, NIGP 133180 (holotype).

Deposited material from the Henson Gletscher Formation. - From Fimbuldal section (Fig. 5), GGU collection 218610: pygidium under MGUH 29372; GGU collection 218611: cranidium under MGUH 29369; GGU collection 218682: cranidium under MGUH 29362, pygidium under MGUH 29363; GGU collection 482321: dorsal carapace under MGUH 29359, five cranidia under MGUH 29357, 29364, 29365, 29366 and 29367; GGU collection 482322: two cranidia under MGUH 29356 and 29360, pygidium under MGUH 29378; GGU collection 482328: carapace under MGUH 29370; GGU collection 482331: cranidium under MGUH 29368, four pygidia under MGUH 29371 , 29373, 29376 and 29379; GGU collection 482332: cranidium under MGUH 29358; GGU collection 482333B: cranidium under MGUH 29361, three pygidia under MGUH 29374, 29375 and 29377.

Additional material. - Abundant material from GGU collections 218610, 218611, 482331, 482321, 482326, 482322, 482328, 482332, and 482333B.

Diagnosis (new). - Species of Ovatoryctocara with moderately long ( $\mathrm{ca} 65$ to 75 percent pygidial length) and comparatively broad pygidial axis (axial ring of anterior segment of $\mathrm{ca} 29$ to 37 percent pygidial width) composed of with 6 (sometimes 5, rarely 7) axial rings; pygidial postaxial region usually slightly upturned and elevated above the adjacent posterolateral pleural areas. Cephalon of large individuals with moderately broad, medially expanded glabella.

Description of the adult morphology. - Complete dorsal carapaces up to $c a 6 \mathrm{~mm}$ in length in the present material.

Glabella lyriform with a notable median expansion across S2, and with a slightly forward expanding frontal part; divided by the occipital furrow and the pits $\mathrm{S} 1-\mathrm{S} 4$; S0 and S1-S4 more-or-less equally spaced from each 
other, the anterior glabellar lobe slightly longer (sag. and exsag.) than L0-L4; the pits of S1-S3 situated well distant from the axial furrow, the $\mathrm{S} 1, \mathrm{~S} 2$ and $\mathrm{S} 3$ pairs connected by a faint furrow, connected with the axial furrows by slightly better impressed furrows; S4 a pair of slightly shallower and smaller pits than the faintly triangular S1-S3, situated close to the axial furrow. Faint longitudinal furrows present from S1 through S3, but dorsoventral compaction regularly enhances their depth and creates conspicuous furrows across the pits of S0 through S4. Frontal lobe in younger individuals with the tendency to develop a sagittal median sulcus that creates frontal lobe consisting essentially of a pair of bulbous structures (Fig. 17E, F). Occipital furrow shallow to moderately well developed medially, with short and clearly deeper lateral sections rising from pit-like depressions. Occipital ring with slightly curved posterior margin, with a faint median node.

Eye lobe moderately long, slightly curved, somewhat oblique to axis, anterior margin in transverse line with L4, posterior end in transverse line with L2; palpebral lobe fairly narrow, rises from moderately deep and narrow palpebral furrow and proceeds into shallow and often inconspicuous to obsolescent eye ridge directed inward and forward to axial furrow. Margin between palpebral lobe and eye ridge marked by a shallow depression.

Fixigenae moderately wide, of around 20 percent cranidial width across posterior part of eye lobes and $c a$ 40-45 percent glabellar width across posterior part of eye lobes; extend into wide, wing-like postocular areas.

Anterior border narrow (sag.) and thread-like in front of the glabella, slightly wider anterior to the genal fields. Anterior border furrow a narrow (sag. and exsag.) incision. Genal field a fairly narrow (exsag.) oblique area. Posterior border narrow to moderately wide (exsag.), convex, rapidly expanding from narrow section at axial furrows and to a maximum posterior to the posterior end of the eyes. Posterior border furrow well-defined, narrow, moderately deep, more-or-less straight in the proximal portion, with a slight rearward swing starting posterior to the posterior end of the eyes and somewhat narrower and shallower towards the suture. Anterior branch of suture curves forward and slightly inward when reaching anterior border furrow. Posterior branch of the suture directed nearly straight outward, then rapidly swinging backward to create large posterolateral projections.

Thorax of four segments. Axial ring of anterior segment with wide (sag. and exsag.) rearward swinging articulating furrow with shallow apodemal pit distally. Axial rings with faint lateral inflation and a deep pit of articulating process in the axial furrow. Pleurae faintly backward directed, genal spines short. Pleural furrows moderately deep, curving slightly back from the axial furrow, then straight and directed faintly obliquely across the pleura. Second to fourth segments similar, but with a less backward swinging articulating furrow and with slightly more rearward directed pleurae.

Pygidium in adults with 6 (sometimes 5, rarely 7) axial rings and minute terminal axial piece, axis (except for articulating halfring) variably of $c a 65$ to 75 percent pygidial length. Behind this area is a slightly convex area with a faint swelling creating a faint kink in the course of the posterior margin and a slightly upturned short section of the posterior margin in posterior view. Axial rings distinctly convex (sag. and exsag.) with slightly swollen lateral portions, separated by fairly broad (sag. and exsag.) furrows. Axial ring of anterior segment of $c a 29$ to 37 percent pygidial width. Articulating halfring crescentic, sag. narrow wide, transversely convex and well raised from articulating furrow. Pleural areas convex. Pleurae 1-5 progressively backward directed, medially divided by well impressed, slightly backward curved pleural furrows. Interpleural furrows less well developed than pleural furrows, slightly fading rearward, shallow between the posteriormost pleurae. Posterior pleurae and posterior area with shallower inconspicuous furrows.

Entire carapace (except for furrows and palpebral

Figure 17. Ovatoryctocara yaxiensis Yuan, Zhao, Peng, Zhu \& Lin, 2009, Henson Gletscher Formation. • A - cranidium, MGUH 29356 from GGU collection 482322. • B - cranidium, MGUH 29357 from GGU collection 482321. • C - cranidium, MGUH 29358 from GGU collection 482332. - D - damaged dorsal carapace, MGUH 29359 from GGU collection 482321. • E - cranidium, MGUH 29360 from GGU collection 482322. - F - cranidium, MGUH 29361 from GGU collection 482333B. • G - cranidium, MGUH 29362, and damaged pygidium, MGUH 29363, from GGU collection 218682. • H - early meraspid cranidium, MGUH 29364 from GGU collection 482321 . • I - immature cranidium, MGUH 29365 from GGU collection 482321. • J - immature cranidium, MGUH 29366 from GGU collection 482321. • K - immature cranidium, MGUH 29367 from GGU collection 482321. • L - cranidium, MGUH 29368 from GGU collection 482331, and meraspid cranidium of ptychoparioid trilobite. • M - juvenile cranidium, MGUH 29369 from GGU collection 218611. • N - articulated dorsal carapace without librigenae, MGUH 29370 from GGU collection 482328. - O - pygidium with articulated thoracic segment, MGUH 29371 from GGU collection 482331, and pygidial fragment of Neopagetina rjonsnitzkii. - P - pygidium with attached thoracic segments, MGUH 29372 from GGU collection 218610. • Q - pygidium, MGUH 29373 from GGU collection 482331. $\bullet \mathrm{R}$ - pygidium with articulated thorax of four segments, MGUH 29374 from GGU collection 482333 . $\bullet$ S - pygidium with two articulated thoracic segments, flattened by compaction, MGUH 29375 from GGU collection 482333B. • T - pygidium, MGUH 29376 from GGU collection 482331, with meraspid cranidium of ptychoparioid trilobite. • U - pygidium, strongly flattened by compaction, MGUH 29377 from GGU collection 482333 B; note bulbous swelling (exfoliated) posterior to axis probably caused by early diagenetic mineralization beneath the test. $\bullet \mathrm{V}-$ pygidium, considerably flattened by compaction, MGUH 29378 from GGU collection 482322. • W - pygidium, MGUH 29379 from GGU collection 482331 . White scale bars 1 mm; black scale bars $0.5 \mathrm{~mm}$. 
Gerd Geyer \& John S. Peel • Cambrian Series 2-3 boundary in North Greenland
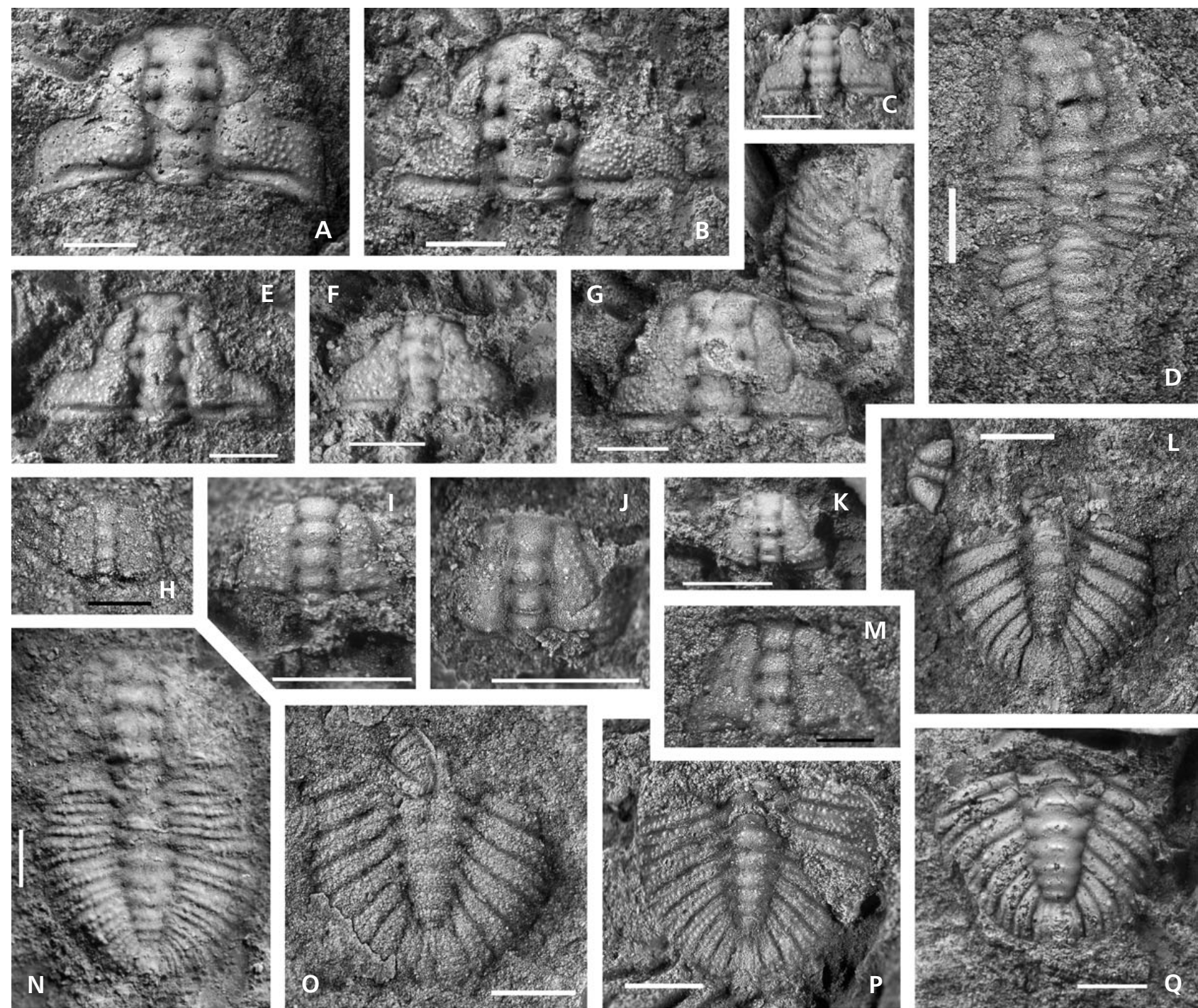

A
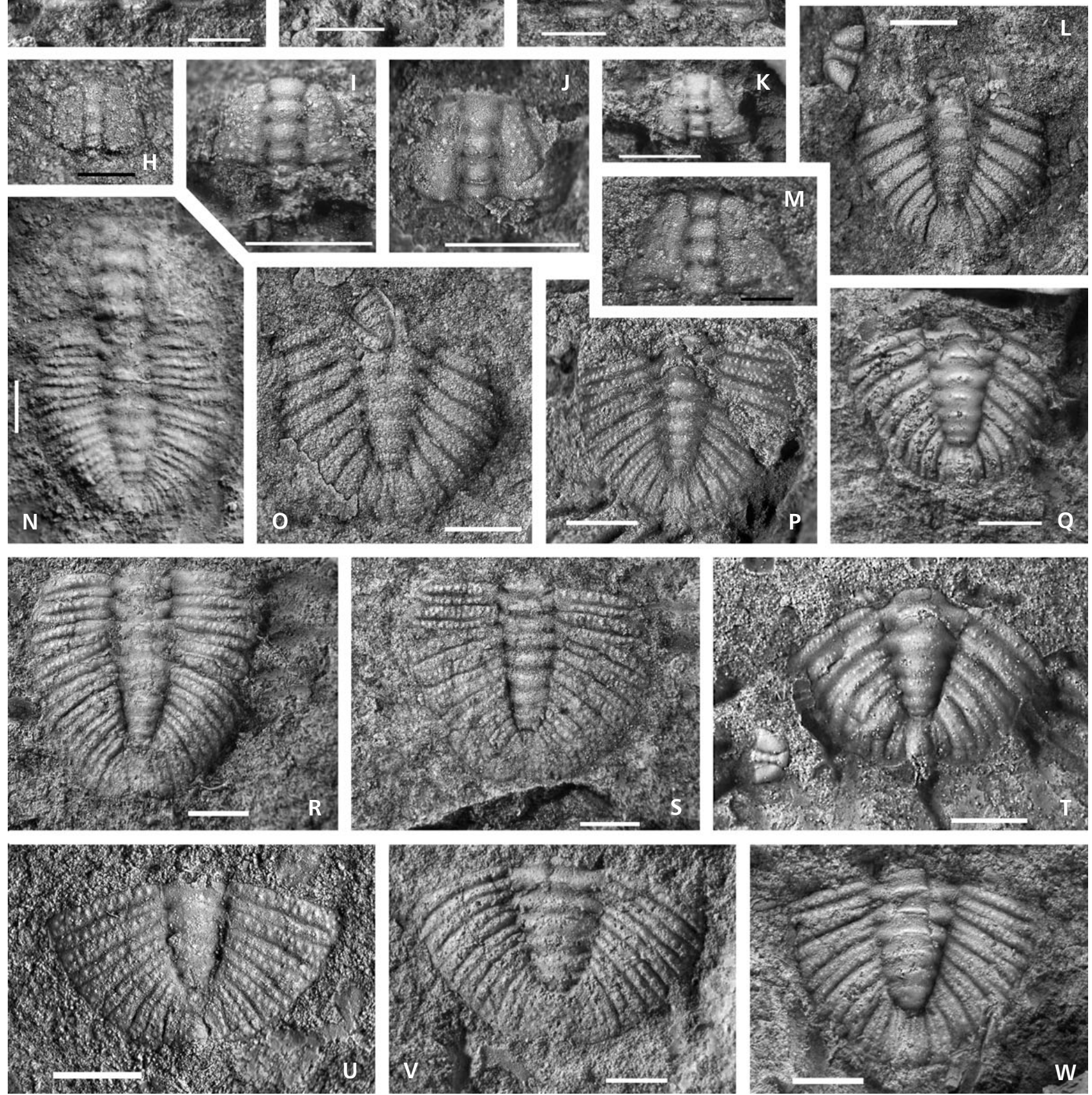
lobes) covered by moderately coarse, more-or-less equally spaced granules which are arranged in somewhat disorderly series on the pygidial pleurae. The size of the granules on the cranidia may vary considerably on the same sclerite (Fig. 17G, I).

Discussion. - See discussion under genus.

Subfamily Oryctocephalinae Beecher, 1897

\section{Genus Protoryctocephalus Chow in Lu et al., 1974}

Type species (by original designation). - Protoryctocephalus wuxunensis Chow in Lu et al., 1974, from the late Early Cambrian of the Guizhou province, south-west China.

\section{Protoryctocephalus arcticus sp. nov.} Figures 18A-Y, 19C, E, H, J

1997 Oryctocephalus vicinus Chernysheva, 1962. - Blaker \& Peel, pp. 116, 117, figs 67.1-67.3, 67.6-67.8, 68.1-68.5.

Holotype. - MGUH 23494, cranidium (Fig. 18B).

Type locality and stratum. - Fimbuldal section, Peary Land, North Greenland; Henson Gletscher Formation, horizon documented by GGU collection 216810 .

Paratypes. - Fimbuldal section (Fig. 5), from GGU collection 218610: ten cranidia under MGUH 23487-23492, 23494, 23495, 29382 and 29394, two librigenae under MGUH 23496-23497, three rostrohypostomal units under MGUH 23493, MGUH 23498 and 29397, two pygidia with articulated thoracic segment under MGUH 23499 and
29412; GGU collection 218611: librigena under MGUH 29396, posterior part of thorax and articulated pygidium under MGUH 29400, pygidium with two articulated thoracic segments under MGUH 29413; GGU collection 218682: posterior part of thorax and articulated pygidium under MGUH 29399, thoracic segment under MGUH 29414; GGU collection 482322: cranidium under MGUH 29385, posterior part of thorax and articulated pygidium under MGUH 29398; GGU collection 482330: cranidium under MGUH 29387; GGU collection 482331: eight cranidia under MGUH 29383, 29384, 29386, 29389, 29390, 23931, 29392 and 29395, librigena under MGUH 29388, incomplete rostrohypostomal unit and external mould of posterior thorax and pygidium, MGUH 29393; GGU collection 482331B: partial thorax under MGUH 29401.

Additional material. - Freuchen Land (Fig. 4), GGU collections 298545, 298553, 301340, 301349, 315097. Lauge Koch Land (Fig. 1D, 1E, locality 2, Blaker \& Peel 1997, fig. 9), GGU collections 271483, 271485. Fimbuldal section (Fig. 5), abundant in GGU collections 218610, 218611, 482330, 482331, 482321, 482326, 482322, 482328, 482332, 482333, 482333B, 482329, and 482323. Løndal section (Fig. 6), GGU collections 225709, 225714, and 271750 .

Diagnosis. - Glabella broadly club-shaped, with four pairs of pit-like glabellar furrows of which S1 is connected medially by a shallow transglabellar furrow; fixigenae of $c a$ two-thirds maximum glabellar width across anterior end of palpebral lobes; palpebral lobes long, posterior ends short distance from posterior border furrow. Thorax of more than 13 segments; thoracic pleurae with long, falcate spines. Pygidium minute, of two axial rings and a tiny terminal area; anterior axial ring with rearward directed lateral portions extending into subtriangular, wing-like pleurae

Figure 18. Protoryctocephalus arcticus sp. nov., Henson Gletscher Formation. • A - paratype, cranidium, MGUH 29380, overlain by hypostome, MGUH 29381, from GGU collection 482331. • B - holotype, cranidium, MGUH 23494 from GGU collection 218610, $\times 8$. $・$ C - paratype, cranidium, MGUH 23495 from GGU collection 218610, × 6.5. • D - paratype, damaged cranidium, MGUH 29382 from GGU collection 218610. $\bullet$ E - paratype, cranidium, MGUH 29383 from GGU collection 482331. $\bullet$ F - paratype, incomplete cranidium, MGUH 29384 from GGU collection 482331, with adjacent pygidium of Ovatoryctocara granulata. $\bullet \mathrm{G}$ - paratype, librigena, MGUH 23497 from GGU collection $218610, \times 11.5$. $\bullet$ H - paratype, cranidium, internal mould with corroded surface, MGUH 29385 from GGU collection 482322. • I - paratype, cranidium, MGUH 29386 from GGU collection 482331. - J - immature cranidium, MGUH 29387 from GGU collection 482330. • K - paratype, librigena, MGUH 29388 from GGU collection 482331. - L - paratype, immature cranidium, MGUH 29389 from GGU collection 482331, with meraspid cranidium of Neopagetina rjonsnitzkii. • M - paratype, immature cranidium, MGUH 29390 from GGU collection 482331. • N - paratype, immature cranidium, MGUH 29391 from GGU collection 482331. - O - paratype, immature cranidium, deformed by oblique compaction, MGUH 29392 from GGU collection 482331. • P - paratype, incomplete rostrohypostomal plate, MGUH 23493 from GGU collection 218610. • Q - paratype, incomplete rostrohypostomal plate and external mould of posterior thorax and pygidium, MGUH 29393 from GGU collection 482331. • R - paratype, juvenile cranidium, MGUH 29394 from GGU collection 218610. - S - paratype, juvenile cranidium, MGUH 29395 from GGU collection 482331. • T - paratype, librigena, largely exfoliated, MGUH 29396 from GGU collection 218611. • U - paratype, rostrohypostomal plate, electronically inverted photograph of external mould, MGUH 29397 from GGU collection $218610 . \bullet \mathrm{V}$ - paratype, posterior part of thorax and articulated pygidium, MGUH 29398 from GGU collection 482322 . $\bullet$ W - paratype, posterior part of thorax and articulated pygidium, MGUH 29399 from GGU collection 218682. $\bullet$ X - paratype, posterior part of thorax and articulated pygidium, MGUH 29400 from GGU collection 218611. • Y - paratype, partial thorax, MGUH 29401 from GGU collection 482331B, and immature cranidium, MGUH 29402, and overturned pygidium of Pagetides elegans; note anterolateral processes of axial rings. Scale bar $1 \mathrm{~mm}$ unless otherwise noted. 
Gerd Geyer \& John S. Peel • Cambrian Series 2-3 boundary in North Greenland
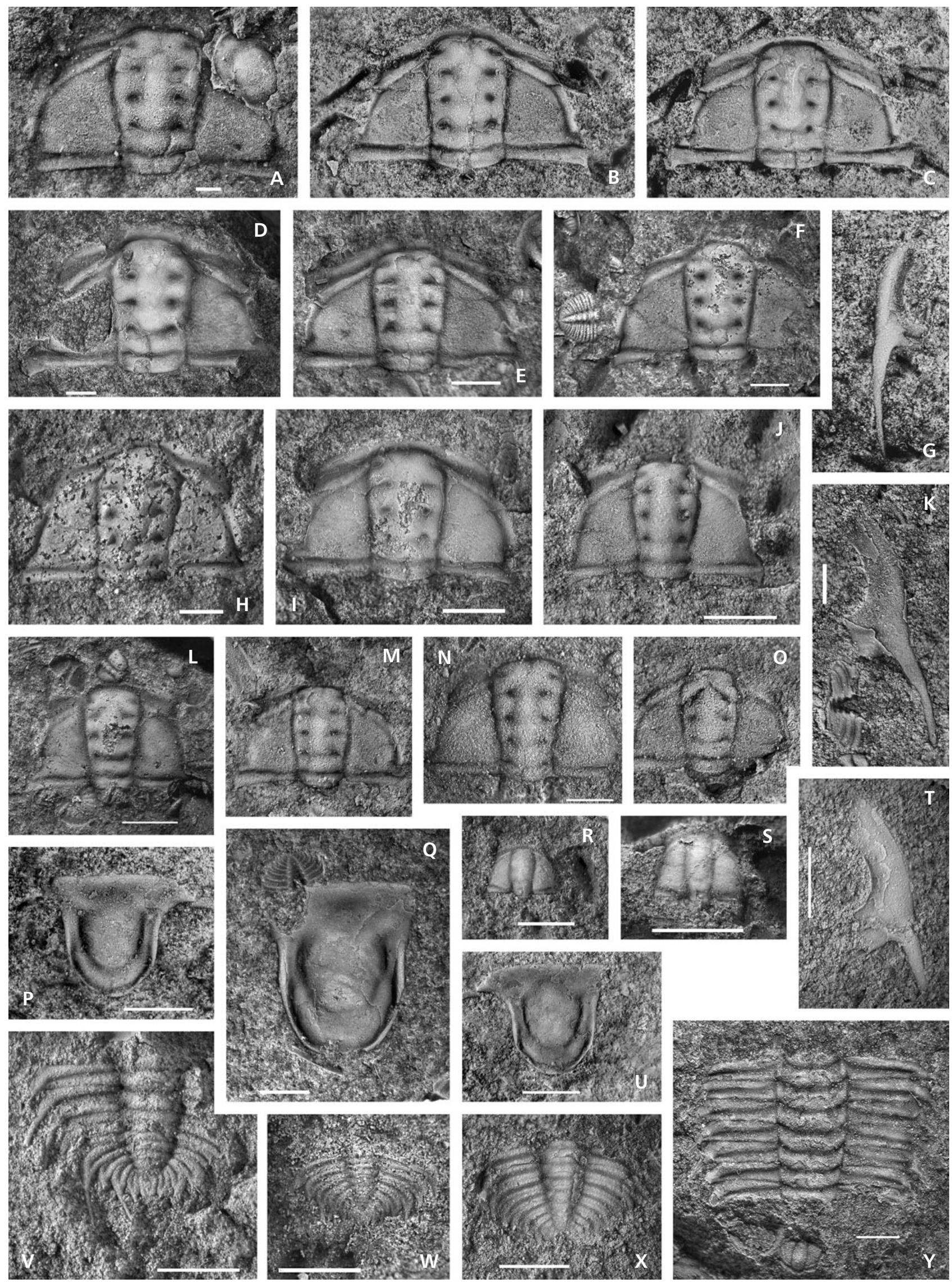
with stout spines; second axial ring with rearward directed undivided pleurae.

Description. - Cephalon subsemicircular, with somewhat shallower curvature of the anterior margin and moderately long extending genal spines. Glabella slightly club-shaped expanding forward from L1 to greatest width (tr.) across level of L3; divided by the occipital furrow and pits S1-S4, S0 and S1-S3 subequally spaced from each other; L4 and the anterior glabellar lobe slightly shorter (sag. and exsag.) than L1 through L3. Pits of S1-S3 form series at equal distances from sagittal axis, some distance in from the axial furrow, all disconnected medially and slightly transversely oval; S4 a shallow and inconspicuous slightly oblique furrow opposite eye ridges, faintly connected in some specimens, commencing close to or at the axial furrow. Occipital furrow with shallow median section which slightly swings backward, lateral sections slightly wider (exsag.) and deeper, with adjacent apodemal pit. Occipital ring moderately wide, with distinct median node; posterior margin of occipital ring with nearly straight median sector, ring thus slightly narrower (sag.) medially than at the slightly expanded lateral sectors.

Eye lobe long, moderately curved, slightly oblique to axis, situated close to the lateral and posterior borders; anterior end in transverse line with L3; palpebral lobe rises distinctly from cheek. Moderately prominent eye ridge directed inward and forward to meet axial furrow opposite S4. Distal portion of the genal field forms a depression and separates eye lobe and eye ridge from lateral border. Fixigenae slightly convex in total, with obsolescent broad obliquely directed depression.

Anterior border narrow (sag.), convex, somewhat reduced in sagittal breadth in front of the glabella and sometimes swinging somewhat anteriorly, steeply upturned from anterior border furrow, broadening laterally in front of the genal fields creating conspicuous differences in breadth in some specimens' axial furrow and merging with the convex lateral border. Anterior border furrow narrow in front of the glabella, merging with the sunken genal fields, forming conspicuously wider depressions. Anterior branch of suture curves forward and inward in a gentle curvature. Posterior border moderately wide (exsag.) and convex throughout, slightly widening and with a rearward curving distal portion posterior to the eye lobes. Posterior border furrow straight, narrow, well-defined.

Librigena with a moderately wide (tr.) and moderately convex ocular platform; lateral and posterior border moderately broad, extending into the base of a moderately long to long genal spine which tapers rapidly; posterior border obliquely dissected by the ocular suture, its librigenal sector short. Lateral and posterior border furrows a shallow and poorly defined groove. Lateral margin with a notable indentation at the base of the genal spine.
Complete thorax unknown, probably of more than 13 segments. Axial rings of more-or-less uniform length (sag. and exsag.), the length reduced progressively posteriorly; posterior lobe of axial ring highly convex to furnish well-developed and strongly convex (sag.) and broad articulating half-ring of adjacent segment. Articulating furrow narrow (sag. and exsag.). Each axial ring has a lateral, slightly inflated extension and a pit of articulating process in the shallow axial furrow. Pleurae (exclusive of spines) widest at third segment, decreasing progressively in transverse width, slightly backwardly curved in the posterior third of the thorax. Pleural furrows moderately wide, slightly backwardly directed from the axial furrow, then directed slightly obliquely across the pleura, terminating well distant from posterior margin. Pleural spines short and falcate anteriorly, becoming progressively longer and more backwardly directed, exsagittally rearward pointing from ninth or tenth thoracic segment. Pleurae of first thoracic segment reduced in exsagittal breadth abaxially due to the distal broadening of the cephalon's posterior border.

Pygidium minute, consisting of two or three axial rings and a tiny terminal area. Anterior axial ring with narrow articulating halfring, lateral portions sharply bent rearward directed, extending into subtriangular, wing-like pleurae with exsagittal pleural furrows commencing almost at the anterior margin and extending over about two-thirds the length and with stout spines. Second axial ring with rearward directed undivided pleurae. Terminal area a transversely narrow strip divided by shallow longitudinal furrows (Figs 18V, 19C, E, H).

Rostrohypostomal plate shield-shaped, subrectangular in outline, with strongly curved posterior margin. Rostral part narrow, smooth, with low curvature at anterior margin, merely a steeply upturned (in ventral view) band, which is almost perfectly fused with hypostomal sector, defined by a change in concavity. Middle body divided by a strongly arcuate middle furrow. Anterior portion pronouncedly convex, longitudinally elliptical in outline, anterolaterally proceeding into low obliquely directed lobes and with a small median depression anteriorly. Posterior portion smaller, slightly inflated, anterolaterally merged with lateral boder. Macula small, smooth externally, adjacent to the inner edge of the doublure. Lateral border anteriorly a narrow blade-like strip normal to axis, fused with anterior projections of the posterior portion of the median body and forming a moderately broad lobe, terminated posterior by extended node-like swellings. Posterior border narrow, strongly convex, defined by well-developed narrow, moderately deep border furrow. Anterior wing steeply inclined. The connective suture obviously did not only bound the rostral plate, but appears to have continued along the anterolateral edge of the anterior wing, separating it from the almost vertical inner edge of the doublure. 
Surface of glabella, fixigenae and cephalic border, as well as axial rings and thoracic pleurae, often with prosopon of inconspicuous tiny granules. Surface of fixigenae covered with caeca of irregular meshes. All furrows smooth.

Discussion. - The genus Protoryctocephalus was previously known only from species found on the Yangtze Platform, South China. The three well-known species, $P$. wuxunensis Chow in Lu et al., 1974 from the Wuxun Formation of Danzhai County, southeastern Guizhou, P. balangensis Zhao \& Yuan in Yuan et al., 2002 from the lowermost Kaili Formation of the Danzhai and Taijiang Counties, southeastern Guizhou, and P. elongatus Zhao \& Yuan in Yuan et al., 2002 from the lowermost Kaili Formation of the Taijiang County, southeastern Guizhou, form a clade of species with a high degree of similarity distinguished by slight differences in the glabellar morphology and the number of thoracic segments.

Protoryctocephalus arcticus sp. nov. has the same pattern of diagnostic characters but differs from all three species in its more slender glabella, librigenae with a narrower ocular platform, and a smaller pygidium with strongly backward directed pleurae fused medially to a small platform, but without a long sword-like median spine.

\section{Genus Oryctocephalus Walcott, 1886}

Type species (by original designation). - Oryctocephalus primus Walcott, 1886, from the Pioche Formation, Highland Range, Pioche District, Nevada, U.S.A.

\section{Oryctocephalus cf. indicus (Reed, 1910)}

Figure 19A

Material. - Single well preserved cranidium (deposited under MGUH 29403) and a cranidial fragment, both from Fimbuldal section (Fig. 5), GGU collection 482335.

Description. - Cranidium subtrapezoidal, length $2.2 \mathrm{~mm}$, three-fourths cranidial width across posterior tips of eyes, with low (sag. and tr.) convexity; anterior margin slightly curved.

Glabellar with low convexity, length more than 95 percent cephalic length, maximum width $c a 37$ percent cranidial width across centre of eyes; glabella slightly tapering forward, widest across S1, width anterior end ca 75 percent maximum glabellar width, frontal lobe not expanded, without a distinct median sulcus but with faint indentation at anterior rim. Lateral glabellar furrows a combination of subcircular, faintly longitudinally extended pits and furrows connecting them medially. S1 with quite sharply incised, slightly rearward swinging furrow across the glabella, S2 with shallow, broad furrow, S3 with smaller pits connected by a very shallow furrow; S4 consisting of pits adjacent to the axial furrows, not connected medially. Occipital furrow consists of a pair of pits close to the axial furrows, connected by a narrow, sharp, straight furrow. Occipital ring narrow to moderately wide (sag. and exsag.), its posterior rim well curved, maximum sagittal length $\mathrm{ca} 15$ percent cephalic length.

Axial furrows moderately well impressed and uniform in depth, sinuous around glabellar pits. Preglabellar field absent. Preglabellar furrow well impressed, quite narrow, merged with anterior border furrow, which is slightly wider in front of preocular fields. Anterior border narrow (sag. and exsag.), slightly convex, slightly upturned, of uniform breadth (sag. and exsag.), slightly and evenly curved.

Fixigena slightly convex, maximum width across the posterior part of the palpebral lobes $\mathrm{ca} 28$ percent cranidial width, covered by faint radial caeca. Palpebral lobe narrow, moderately curved, moderately long (33 percent cephalic length), anterior end opposite L3, posterior end opposite $\mathrm{S} 1$; palpebral furrow narrow and shallow. Eye ridge fairly well defined, reaching glabella at S4, directed back from glabella with a slight curvature. Posterior area of fixigena extending into a small posterolateral projection.

Posterior border moderately convex, slightly expanding distally. Posterior border furrow well impressed, with steeper anterior rim, nearly uniformly deep and wide, almost straight.

Librigena, thorax, and pygidium unknown.

Discussion. - The complete cranidium shows a nearly perfect congruence with cranidia from the Kaili Formation of the Guizhou Province, south-west China (e.g. Yuan et al. 2002, Zhao et al. 2008) and from the Emigrant and the Monola formations of Nevada, U.S.A. (e.g. Sundberg \& McCollum 2003), assigned to Oryctocephalus indicus. Unfortunately, the pygidium is unknown so that the determination has to remain tentative.

\section{Genus Lancastria Kobayashi, 1935}

Type species (by original designation). - Olenopsis roddyi Walcott, 1912 from the Lower Cambrian Kinzers Formation of Lancaster County, Pennsylvania, U.S.A.

Discussion. - The question as to whether or not Goldfieldia Palmer, 1964 is a junior synonym of Lancastria Kobayashi, 1935 cannot be answered with confidence at this time. Only cranidia are known of the type species, G. pacifica Palmer, 1964, from the Saline Valley Formation of the Goldfield district, Nevada, and these share almost all of the diagnostic characters with the specimens from the Henson 
Gletscher Formation. An additional species, G. ninguis Palmer \& Gatehouse, 1964, from the early Middle Cambrian Xystridura faunule of Mount Spann, Argentina Range, Antarctica, also is known only from isolated cranidia.

The type material of Lancastria roddyi (Walcott, 1912), the type species of Lancastria, consists of specimens that are considerably distorted tectonically and are characterized by transglabellar glabellar furrows S1, ocular ridges in a comparatively anterior position and lack a median sulcus on the frotal lobe of the glabella. In this respect, the species present in the Henson Gletscher Formation and described below may prove to be better placed under Goldfieldia, if regarded as a separate genus, or even dealt with under the yet monotypic genus Paraoryctocephalops Tomashpolskaya, 1960, the type species of which was originally described as Paraoryctocephalops plana Tomashpolskaya, 1960 (in Khalfin, 1960) from the SayanAltay Foldbelt (see discussion below).

Changaspis Li, 1961 (in Qian, 1961), known from several species occurring in coeval strata on the Yangtze Platform, is closely related. Yuan et al. (2001) suggested that Changaspis spp. from the Balang Formation of Guizhou differ from Lancastria in having a glabella which gradually expands forwards rather than having subparallel sides, and with pit-like glabellar furrows instead of groove-like furrows as in Lancastria plana.

The most characteristic difference, however, is that the pygidium in Changaspis is very small and consists of only one axial ring which extends posteriorly into a long and slender pygidial spine (McNamara et al. 2006). Thus, applying a strict set of characters, Changaspis should not be regarded as a junior synonym of Lancastria as proposed by earlier authors (e.g. Zhang 1989). On the other hand, the specimens described below as Lancastria cf. plana appear to bracket both genera. In addition, the characteristic pygidium (e.g. Fig. 19B) also indicates close morphological resemblance with Protoryctocephalus so that recognition of a Subfamily Lancastriinae Kobayashi, 1935 is to be regarded as arbitrary. It should be noted, however, that Sundberg \& McCollum (1997) regarded Lancastria roddyi as representing part of a stem group from which Oryctocephalus may have evolved.

\section{Lancastria cf. plana (Tomashpolskaya, 1960)}

Figures 19B, D, F-G, I, K, L, 20A-U

1986 Changaspis sp. nov. - Blaker, p. 68.

1997 Lancastria plana (Tomashpolskaya in Khalfin, 1960). - Blaker \& Peel, pp. 118-122, fig. 69.1-69.4, 70, 71.1, 71.3-71.5, 71.7, 71.8, 72.2.

2005 Lancastria plana (Tomashpolskaya, 1960). - Geyer, p. 89 , fig. $4.7-4.9$.
Deposited material. - Freuchen Land section (Fig. 4), GGU collection 315095: nearly complete carapace under MGUH 23500, partial thorax with attached pygidium under MGUH 23504, cranidium under MGUH 23509; GGU collection 301341: thorax with attached pygidium and librigenae with attached rostrohypostomal plate of the same individual as part and counterpart under MGUH 23501 and 23502, two cranidia under MGUH 23510 and 23511. Lauge Koch Land (Fig. 1D, 1E, locality 2, Blaker \& Peel 1997, fig. 9), GGU collection 271485: four cranidia under MGUH 23505-23508, librigena under MGUH 29426. Fimbuldal section (Fig. 5), GGU collection 218610: pygidium under MGUH 29407; GGU collection 218610: cranidium under MGUH 29428;GGU collection 482321: three cranidia under MGUH 29418, 29419 and 29427, articulated thoracic pleurae under MGUH 29406, posterior part of thorax and articulated pygidium under MGUH 29416, pygidium under MGUH 29408, two rostrohypostomal units under MGUH 29409 and 29410, librigena under MGUH 29411; GGU collection 482331A: fragment of librigena under MGUH 29405; GGU collection 482322: two cranidia under MGUH 29423 and 29424; GGU collection 482324: cranidium under MGUH 29415; GGU collection 482328: carapace under MGUH 29430; GGU collection 482331: three cranidia under MGUH 29416, 29417 and 29420, librigena under MGUH 29429; GGU collection 482332: cranidium under MGUH 29425; GGU collection 482333: cranidium under MGUH 29422; GGU collection 482333B: cranidium under MGUH 29427. - Løndal section (Fig. 6), GGU collection 225707: partial thorax with attached pygidium under MGUH 23503.

Additional material. - Freuchen Land section (Fig. 4), GGU collections 301341, 315095 (abundant), 315096, 315107. Lauge Koch Land (Fig. 1D, 1E, locality 2, Blaker \& Peel 1997, fig. 9), GGU collection 271485 (abundant). Fimbuldal section, GGU collections 218610, 482331, 482321, 482324, 482322, 482328, 482332, 482333, and 482333 B.

Description. - Cephalon subsemicircular, with shallower curvature of the anterior margin and moderately long posterolaterally extending genal spines.

Glabella slightly expanding forward, greatest width (tr.) across level of L4; divided by the occipital furrow and pits S1-S4, S0 and S1-S3 subequally spaced from each other; L4 and the anterior glabellar lobe slightly shorter (sag. and exsag.) than L1 through L3. Pits of S1-S3 situated a short distance in from the axial furrow, all disconnected medially and transversely subtriangular; S4 a shallower and smaller than S1-S3, mostly transversely slit-like, commencing close to the axial furrow. Occipital furrow with narrow (sag.) median section which slightly swings backward, lateral sections slightly wider (exsag.), 

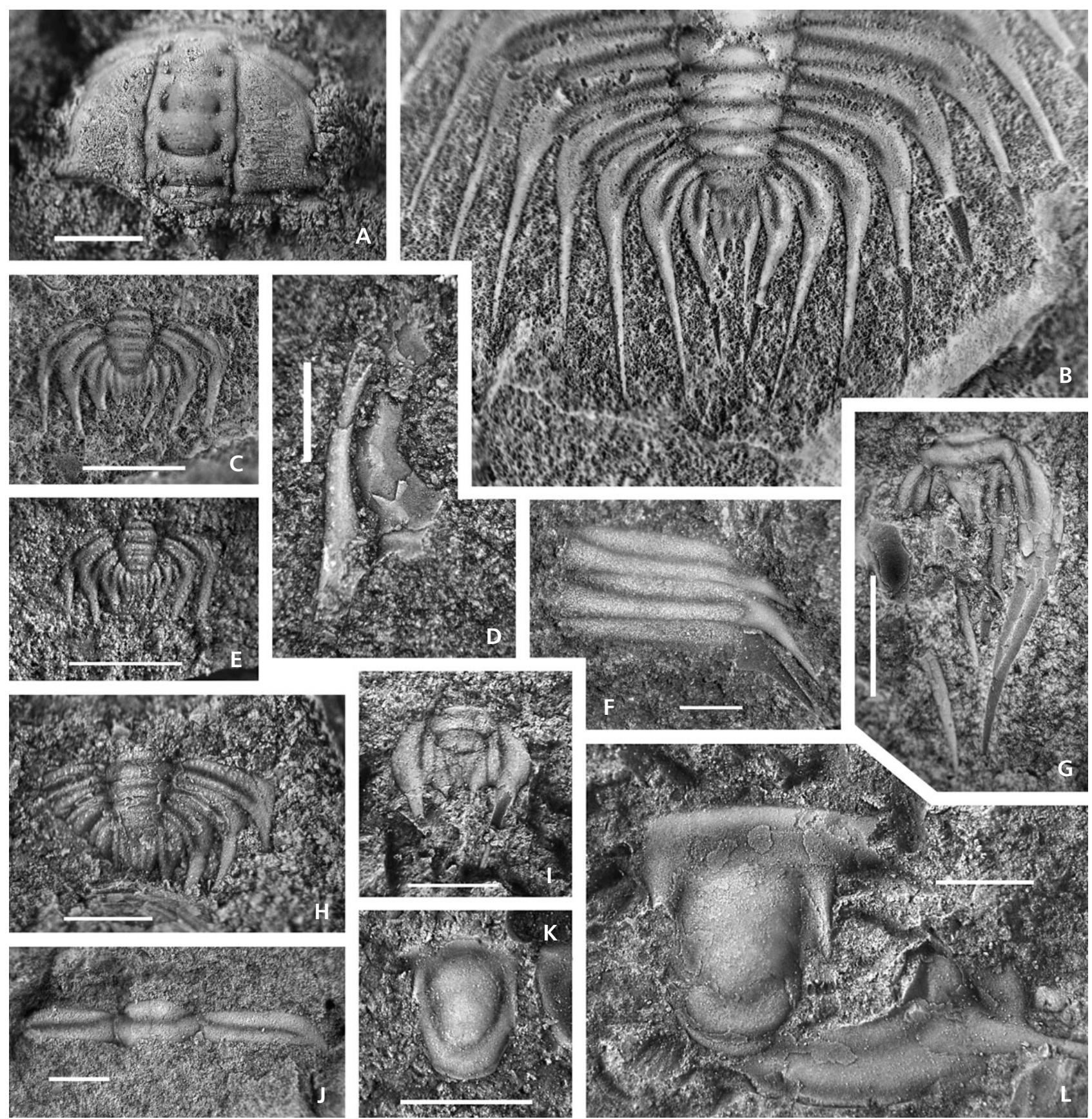

Figure 19. Henson Gletscher Formation trilobites. • A - Oryctocephalus cf. indicus (Reed, 1910), incomplete cranidium, MGUH 29403 from GGU collection 482335. B, D, F, G, I, K, L-Lancastria cf. plana (Tomashpolskaya, 1960). B - posterior part of thorax and articulated pygidium, electronically inverted photograph of external mould, MGUH 29404 from GGU collection 482331, $\times 25$. D - fragment of librigena, dorsal view showing granules on ventral doublure, MGUH 29405 from GGU collection 482331 A. F - articulated thoracic pleurae, MGUH 29406 from GGU collection 482321. G - pygidium, posteriorly directed spines partially broken off showing external mould with longitudinal fractures caused by compaction, MGUH 29407 from GGU collection 218610. I - incomplete pygidium, MGUH 29408 from GGU collection 482331. K - incomplete rostrohypostomal plate of immature individual, MGUH 29409 from GGU collection 482331. L - fragment of rostrohypostomal plate and incomplete librigena, MGUH 29410 and MGUH 29411 from GGU collection 482331. • C, E, H, J - Protoryctocephalus arcticus sp. nov. C - pygidium with articulated thoracic segment, electronically inverted photograph of external mould, MGUH 29412 from GGU collection 218610. E-pygidium with articulated thoracic segment, MGUH 23499 from GGU collection 218610. H - pygidium with two articulated thoracic segments, MGUH 29413 from GGU collection 218611. J - thoracic segment, MGUH 29414 from GGU collection 218682. Scale bars 1 mm unless magnification otherwise noted. 
with slight curvature, resembling an apodemal pit. Posterior margin of occipital ring with nearly straight median sector, ring thus narrow medially, slightly expanding towards the axial furrows.

Eye lobe long, moderately curved, situated close to the lateral and posterior borders; anterior end in transverse line with L3; palpebral lobe rises from cheek. Prominent eye ridge directed inward and forward to axial furrow opposite L4. Distal portion of the genal field forms a shallow depression and separates eye lobe and eye ridge from lateral border. Fixigenae slightly convex in total, with faint and broad, obliquely directed depression.

Anterior border very narrow (sag.), merely a slightly upturned, brim-like blade, merging with the narrow and convex lateral border. Anterior border furrow a moderately wide to wide (sag. and exsag.) depression sloping from the glabella and the genal fields distally. Genal fields distinctly convex, exsag. broad, with a median longitudinal depression starting some distance from the axial furrows and deepens and grows in exsag. width distally. Anterior branch of suture curves forward and inward in a gentle curvature. Posterior border moderately wide (exsag.) throughout, convex, slightly rearward curving distally of the eye lobes. Posterior border furrow narrow, well-defined.

Librigena with a fairly narrow (tr.) ocular platform which is moderately convex laterally and grades into a considerable convexity close to the posterior border. Lateral border broad (tr.), divided by a shallow, poorly defined longitudinal furrow into a narrow low strip and a much wider internal lobe which extends into the moderately long and slender genal spine, which tapers rapidly from the base, its tip located opposite the third (up to fifth?) thoracic segment. Posterior border relatively low, dissected by the strongly curved ocular suture, its librigenal sector short and with a clear indentation of the posterior margin at the base of the genal spine. Posterior border furrow a shallow and poorly defined groove.

Complete thorax unknown, of more than 13 segments. Axial rings of more-or-less uniform length (sag. and exsag.), the length reduced progressively posteriorly. Narrow (sag. and exsag.) articulating furrow with faint apodemal pit distally. Each ring has a very faint lateral inflation and a deep pit of articulating process in the axial furrow. Pleurae (exclusive of spines) widest at first segment, decreasing progressively in width (tr.), becoming slightly more strongly backwardly directed in the posterior third of the thorax, the third last pair directed exsagittally, the second last and last pairs curved to direct the spines adaxially in a acute angle. Pleural furrows moderately wide, curve slightly back from the axial furrow, then directed slightly obliquely across the pleura, terminating short distance from posterior margin. Pleural spines short anteriorly, progressively longer and more backwardly directed.

Pygidium with one axial ring and a terminal area. Axial ring with distinct articulating halfring, lateral portions sharply bent rearward into a long, crescent-shaped pair of spines with a pleural furrow commencing almost at the anterior margin and extending over the anterior third. Terminal area obviously with some variation in morphology, with one pair or with three sagittal and exsagittal groovelike depressions, extending into a pair of long, rearward directed spines and a tiny shorter median spine (Fig. 19B).

Rostrohypostomal plate shield-shaped, subrectangular in outline, with weakly to moderately curved posterior margin. Rostral part narrow, smooth, with low curvature at anterior margin, merely a slightly upturned (in ventral view) band, which is almost perfectly fused with hypostomal sector, defined by a change in concavity and marked by a wide elliptical median depression. Middle body divided by a strongly arcuate middle furrow. Anterior

Figure 20. Lancastria cf. plana (Tomashpolskaya, 1960), Henson Gletscher Formation. • A - incomplete cranidium with conspicuous caecal pattern on fixigenae, MGUH 29415 from GGU collection 482324. • B - cranidium, MGUH 29416 from GGU collection 482331. • C - nearly complete dorsal carapace of immature specimen with net-like caecal pattern on fixigenae, MGUH 23500 from GGU collection $315095, \times 10.5$. $\bullet$ D - cranidium with gerontic aspects, MGUH 29417 from GGU collection 482331 • E - cranidium, MGUH 29418 from GGU collection 482321 . F - cranidium, MGUH 29419 from GGU collection 482321. $\bullet \mathrm{G}$ - cranidium, MGUH 29420 from GGU collection 482331, with immature cranidium of Protoryctocephalus arcticus sp. nov. - H - cranidium, deformed by compaction, MGUH 29421 from GGU collection 482333. • I - immature cranidium, MGUH 29422 from GGU collection 482333B, overlain by pygidium of Ovatoryctocara granulata. $\bullet \mathbf{J}$ - two cranidia, dorsal side up and overturned, respectively, pressed together by compaction, MGUH 29423 and MGUH 29424 from GGU collection 482322, an example for the frequent style of preservation in shaly strata; $\times 2.1$. $\bullet$ K fragment of meraspid cranidium, MGUH 29425 from GGU collection $482332, \times 8.5$. $\bullet$ L - incomplete librigena, dorsal view of slightly compacted specimen, MGUH 29426 from GGU collection $271485, \times 8$. $\bullet$ M - fairly complete carapace, dorsal view of anterior part showing rostrohypostomal plate slightly detached from librigenae and ventral aspects of anterior part of thorax, MGUH 23501 from GGU collection 301341. • N - juvenile cranidium, MGUH 29427 from GGU collection 482321. • O - juvenile cranidium, MGUH 29428 from GGU collection 218611. • P - librigena, ventral view showing doublure of lateral border and genal spine cracked during compaction, MGUH 29429 from GGU collection 482331, × 8. • Q - imcomplete cranidium, MGUH 23505 from GGU collection 271485, × 5.5. $\bullet$ R, U - damaged carapace with incomplete cranidium and left librigena, MGUH 29430 from GGU collection 482328. R - complete specimen in dorsal view, hypostome underlying remains of glabella in place partly visible. U - detail of thorax showing lateral swellings of axial rings, falcate pleural tips and granulated surface. $\bullet \mathrm{S}$ - partial thorax with attached pygidium, latex cast of external mould with rests of test at some of the axial rings, MGUH 23509 from GGU collection 315095, $\times 9 . \bullet$ T - incomplete cranidium, MGUH 23506 from GGU collection $271485, \times 6$. Scale bar $1 \mathrm{~mm}$ unless otherwise noted. 
Gerd Geyer \& John S. Peel • Cambrian Series 2-3 boundary in North Greenland
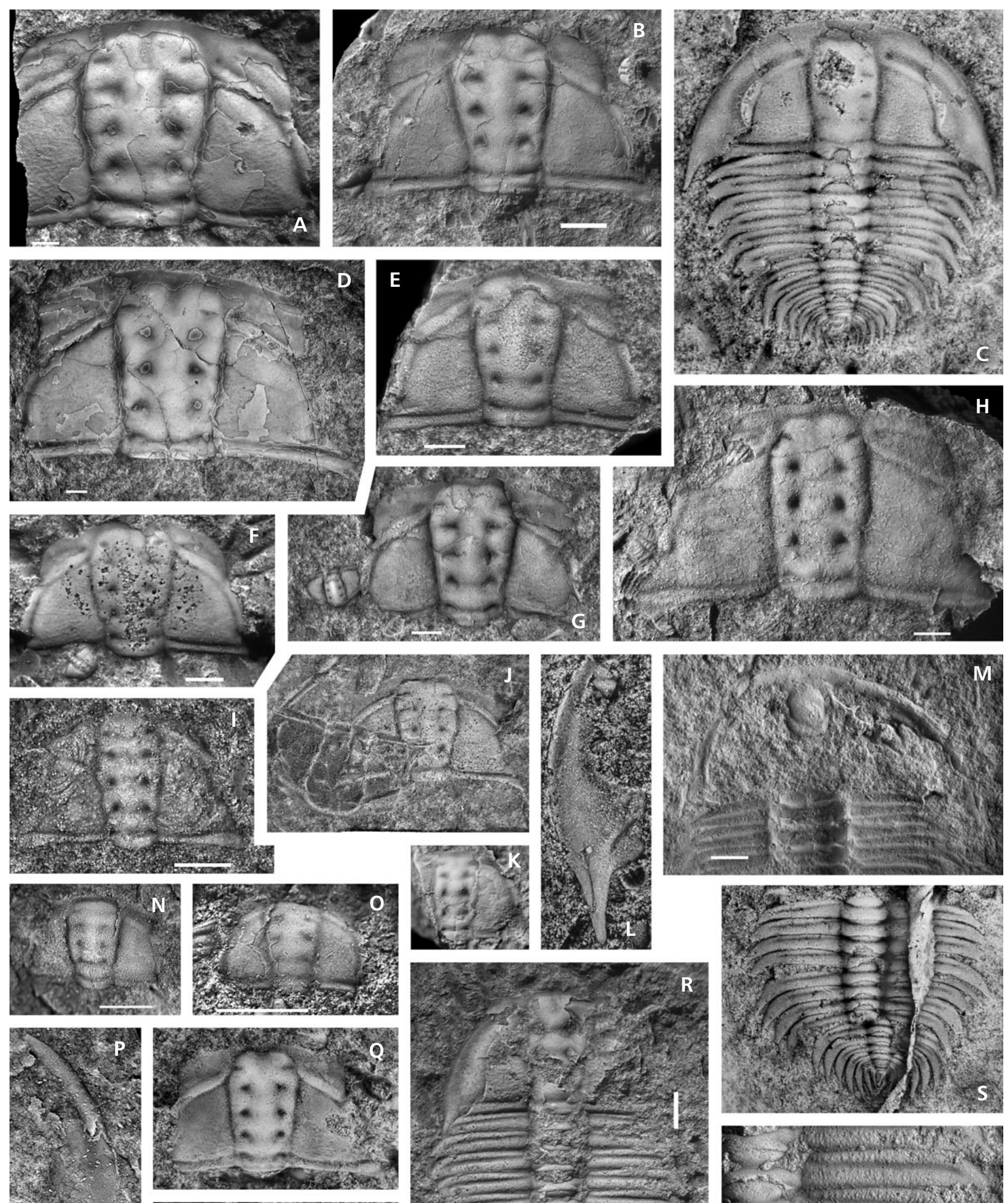

5.
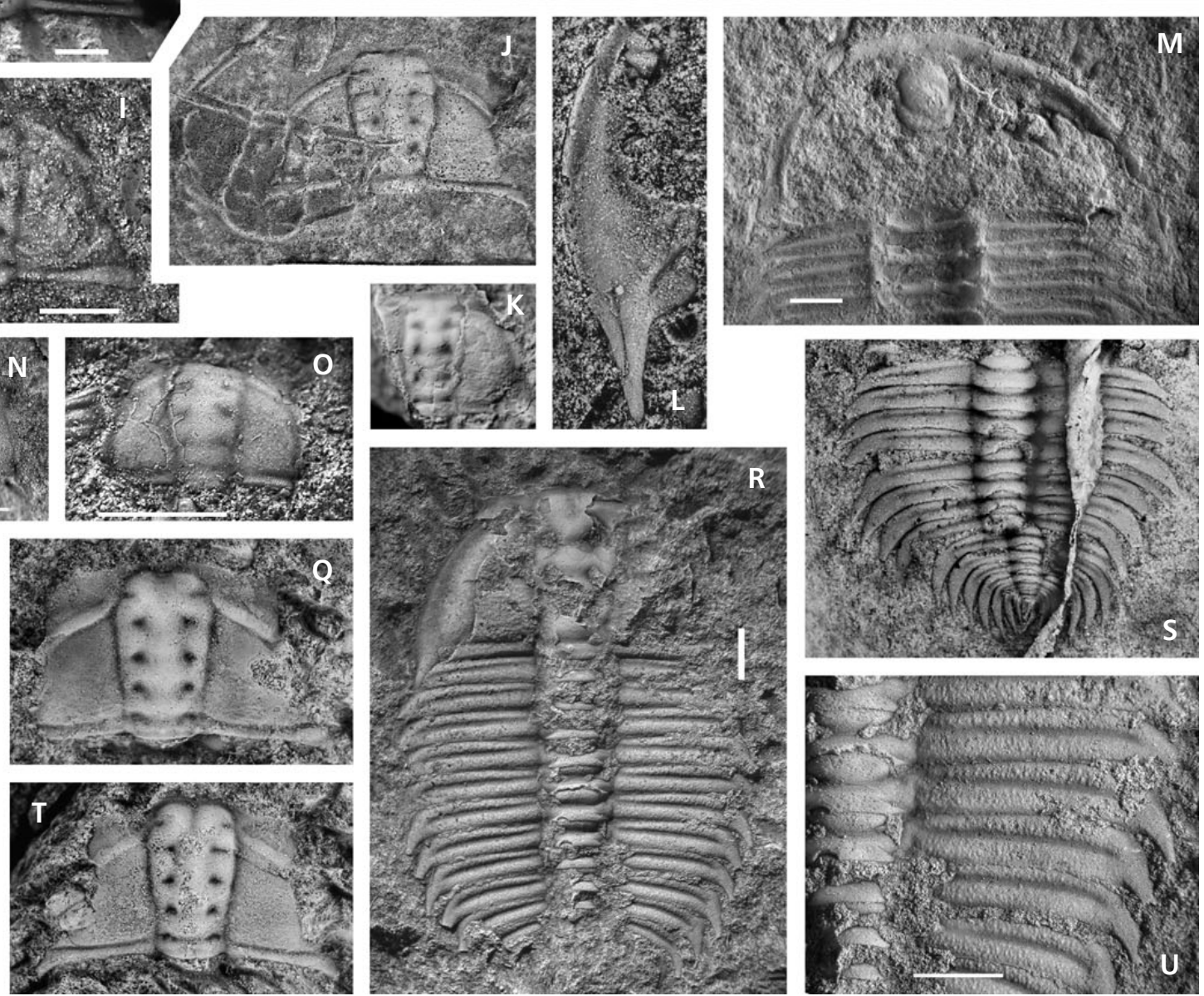
portion pronouncedly conved, longitudinally elliptical in outline, anterolaterally proceeding into low obliquely directed lobes. Posterior portion smaller, slightly inflated, dipping and hence fading anterolaterally along the anterior portion of the middle body. Macula small, smooth externally, adjacent to the inner edge of the doublure. Lateral border a narrow blade-like strip normal to axis. Posterior border equally narrow, convex, slightly lower than lateral border, defined by well-developed narrow, moderately deep border furrow. Anterior wing inclined.

Discussion. - Lancastria plana (Tomashpolskaya, 1960) was originally described as Paraoryctocephalops plana Tomashpolskaya, 1960 (in Khalfin, 1960) from the Sayan-Altay Foldbelt. In the type area it is only known from the cranidium and this has a glabella slightly expanding forward, with a relatively straight anterior rim of the frontal lobe and usually a clear median indention. The specimens from the Henson Gletscher Formation fit well into this morphology. However, the palpebral lobes are slightly longer and the glabella appears to expand more strongly than the specimens from the Sayan-Altay region. The pygidium of the Greenland specimens consists of only an axial ring plus a terminal axial piece and is further characterized by long rearward directed spines. A delicate median spine at the central plate (Fig. 19B) appears to be absent in some specimens. This pygidium resembles the pygidium seen in the holotype of Lancastria roddyi (Walcott, 1912) from the Kinzers Formation at Lancaster, Pennsylvania (see Whittington 1995, pl. 3, figs 4, 5) although Whittington (1995) assigned 7 segments to the pygidium.

A species with similar morphology was described under the name Goldfieldia kunshanensis Zhang \& Zhou, 1985 from the Jiangsu Province, South China. This species is based solely on the cranidium, of which only a single specimen with narrower, more strongly curved and slightly shorter palpebral lobes is figured. Hence, the precise morphological variability is unknown.

Zhao \& Yuan (in Yuan et al. 2002, p. 14, fig. 8) figured a complete specimen assigned to Protoryctocephalus elongatus Zhao \& Yuan, 2002 from the lowermost Kaili Formation of the Wuliu section in southeastern Guizhou. Superficially, this specimen has a very similar morphology to the specimens assigned as Lancastria cf. plana from the Henson Gletscher Formation, but the pygidium is a slightly larger unit with two axial rings and with broader spines; the thoracic segments in general have a tendency towards falcate pleural tips rather than slender spines.

McNamara et al. (2006) briefly discussed the affinities of Paraoryctocephalops plana and concurred with the placement under Lancastria. The authors characterized it as having a thorax with 14 segments and a club-shaped glabella with pit-like furrows.
Order Ptychoparioidea Swinnerton, 1915

Superfamily Ptychopariacea Matthew, 1887

Family unassigned

Discussion. - Faced with considerable morphological variation in certain assemblages of ptychoparioids from the Henson Gletscher Formation, Blaker \& Peel (1997, pp. 123, 124) synonymized a number of mono- and paucispecific ptychoparioid genera of similar, generalized, morphology with the genus Ptychoparella Poulsen, 1927, namely Syspacephalus Resser, 1936, Elrathina Resser, 1937, and Eoptychoparia Rasetti, 1955. This conclusion can not be maintained; it is evident that a more rigorous approach to the analysis of morphological characters is required to unravel the relationships of taxa within this difficult group. Blaker \& Peel (1997) grouped these taxa under a single name, Ptychoparella sp. A, but examination of the collections reveals that a plethora of ptychoparioid trilobites is present in the Henson Gletscher Formation. The precise description of these is beyond the scope of this present study, but we describe two new species which contribute to the stratigraphic correlation within the genera Eoptychoparia and Onchocephalus, respectively.

A logical assignment of the genera described below would have been the family Antagmidae Hupé, 1953. As mentioned above, however, the nominal genus Antagmus Resser, 1936 is based on specimens that are too poorly known for precise recognition (see Sundberg 2007, fig. 9b). Hence, that the genus is a nomen dubium and the name Antagmidae is to be regarded as invalid.

\section{Genus Eoptychoparia Rasetti, 1955}

Type species (by original designation). - Eoptychoparia normalis Rasetti, 1955, from Ville Guay Conglomerate (= Sillery Formation) at Bic, near Lévis, Québec, Canada.

Discussion. - Eoptychoparia Rasetti, 1955 perhaps represents the least distinctive genus of ptychoparioids and may therefore count as a perfect example of an average trilobite. The name of Rasetti's (1955) type species confirms this opinion and Rasetti (1955, p. 14) referred to this condition in differentiating the genus from similar ptychoparioids mostly on the basis of the absence of distinct characters. A very similar genus with an equally generalized character set was introduced as Ptychoparella Poulsen, 1927. The type species of Ptychoparella, P. brevicauda Poulsen, 1927 from inner platform carbonates of the Cape Wood Formation of Inglefield Land, North-West Greenland, is known only from imperfectly preserved sclerites; it shows a distinctly tapering glabella with a gently rounded front, conspicuously backward curving eye ridges leading to small palpebral lobes at the level of $\mathrm{S} 1$ and a multisegmented 

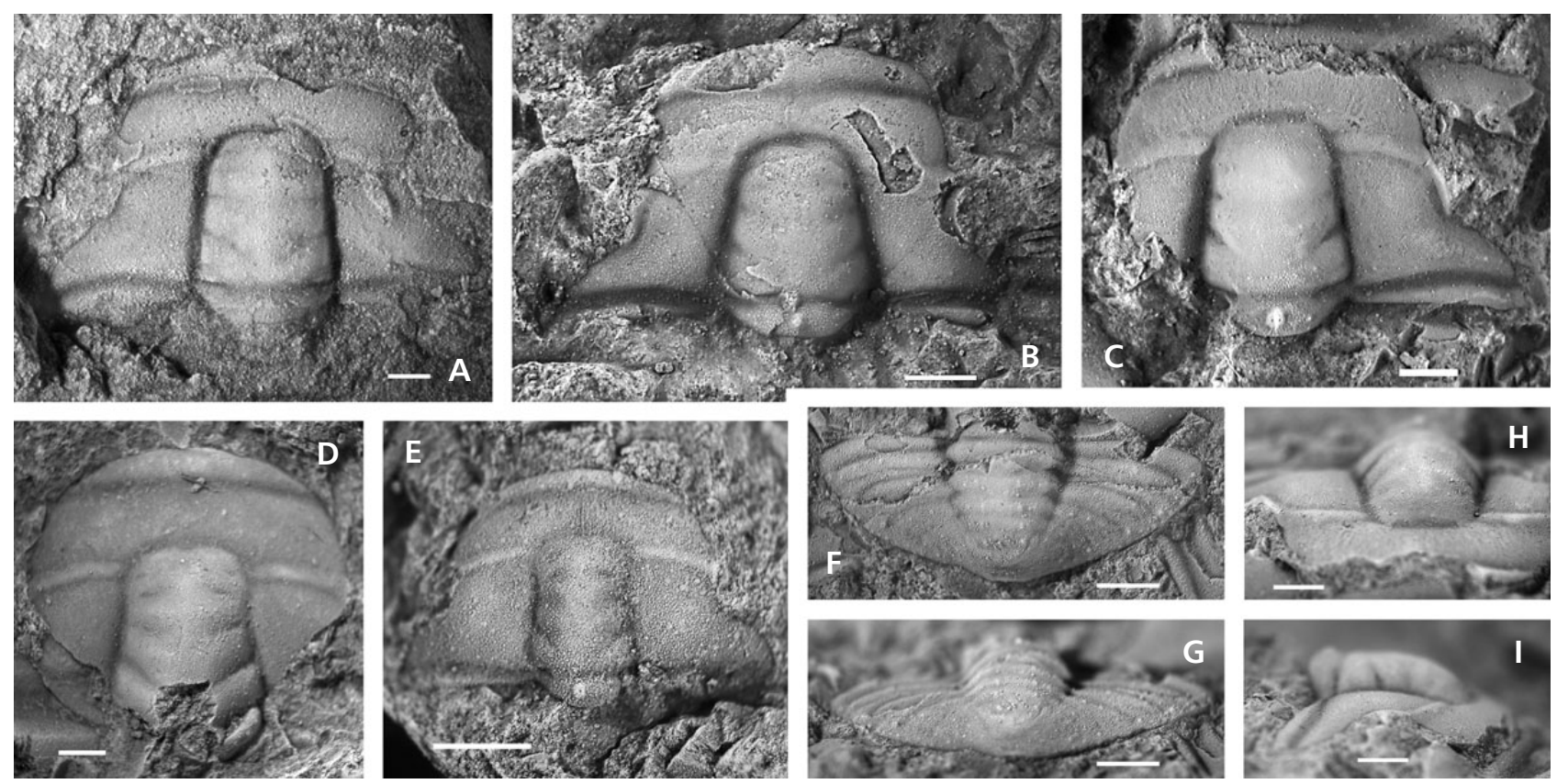

Figure 21. Eoptychoparia pearylandica sp. nov., Henson Gletscher Formation. • A - paratype, incomplete cranidium, exfoliated, MGUH 29431 from GGU collection 225706. • B - paratype, cranidium, MGUH 29432 from GGU collection 301348. • C, H, I - holotype, incomplete cranidium, MGUH 29433 from GGU collection 225707; dorsal, anterior and right lateral views. $\bullet$ D - paratype, cranidial fragment, MGUH 29434 from GGU collection 225707. • E - paratype, immature cranidium, MGUH 29435 from GGU collection 225707; note prosopon of small, densely spaced granules. - F, G - pygidium, MGUH 29436 from GGU collection 225707, showing pairs of moderately large granules on axial rings and irregularly spaced granules on pleural fields; dorsal and posterior views. White scale bars $1 \mathrm{~mm}$.

pygidium with a fairly well recognizable border. Ptychoparella brevicauda, as well as all other species assigned to this genus and with equally generalized character sets, occurs in younger strata of middle Cambrian age.

\section{Eoptychoparia pearylandica sp. nov. Figure 21A-I}

Holotype. - Cranidium, MGUH 29433 from GGU collection 225706.

Type locality and type stratum. - Løndal section (Fig. 6), Peary Land, North Greenland, Henson Gletscher Formation, horizon characterised by GGU collection 225706 .

Paratypes. - Løndal section (Fig. 6), GGU collection 225706: cranidium under MGUH 29431; GGU collection 225707: three cranidia or cranidial fragments under MGUH 29434 and 29435 one pygidium, MGUH 29436. Freuchen Land section (Fig. 5), GGU collection 301348: one cranidium under MGUH 29432.

Derivatio nominis. - Named after its occurrence in Peary Land, North Greenland.

Diagnosis. - Species of Eoptychoparia with narrow, lenti- cular palpebral lobes with anterior ends in transverse line with S3; frontal lobe subtruncate, fairly wide; occipital ring with prominent median node. Preglabellar field fairly broad (sag.), ca 1.5 times width of anterior border; anterior border moderately broad and moderately convex. Pygidium with axis of 4 rings, the posterior part of which rests on a slightly elevated platform.

Description. - Cranidium subsemicircular in outline, moderately convex. Ratio length to width $c a$ 0.6.

Glabella transversely moderately to strongly convex, lateral profile gently convex in the posterior two-thirds, rapidly sloping towards anterior; gently, more or less equally tapering forward from occipital furrow, with a minute constriction across L3; frontal lobe subtruncate, with feeble indentation; length $\mathrm{ca} 70$ percent cephalic length, transverse width across L1 slightly more than 40 percent transverse cranidial width across centre of eye lobes. Four pairs of glabellar furrows, moderately well impressed near axial furrows, slightly and progressively less well impressed from S1 to S4 and fading towards midline; S1 distinctly curved backward from axial furrows, disconnected for short distance; S2 slightly backward directed; $\mathrm{S} 3$ relatively faint, normal to axis; S4 faint, slightly forward directed and with weak curvature. Occipital furrow faintly backward directed from axial furrows, with narrow lateral sections and a much wider median section. Occipital 
ring with nearly straight, moderately backward directed posterolateral margins and a gently curved median section of its posterior margin so that the lateral portions taper to narrow lobes whereas the occipital ring measures sagittally ca 12 percent cephalic length; with prominent median node.

Axial furrows well incised laterally, less so in front of the glabella.

Eye lobe short, exsag. of $\mathrm{ca} 15$ percent cephalic length, clearly oblique to axis, anterior end in transverse line with $\mathrm{S} 3$, posterior end slightly anterior to level of S1; palpebral lobe rises steeply from cheek almost without a defined palpebral furrow, narrow lenticular in dorsal view. Prominent eye ridge directed inward and forward to axial furrow opposite immediately anterior to $\mathrm{S} 4$, with faint continuation to frontal lobe across deep axial furrow.

Fixigenae gently convex, moderately wide (tr.). Posterior area of fixigena extends into a considerably large, wing-like posterolateral projection.

Anterior border distinctly convex, moderately broad (sag.), growing from the suture to the sagittal line to nearly double breadth ( $\mathrm{ca} 12$ percent cephalic length), without median boss or notable sagittal thickening; anterior margin more or less equally curved. Anterior border furrow a moderately wide (sag. and exsag.) depression sloping from the glabella and the genal fields distally, with only a faint shallower section medially. Genal fields gently to moderately convex, exsag. broad. Anterior branch of suture parallel or faintly diverging from anterior ends of eyes, then curving inward in a gentle curvature after about one-third its length and cutting the anterior border obliquely. Posterior border moderately wide (exsag.) except for narrow adaxial section, distinctly convex, directed slightly posterolaterally. Posterior border furrow moderately wide (exsag.) and moderately deep, shallower adaxially, with slight curvature posterior to abaxial sector of fixigena.

Surface of cranidium densely covered with small granules, particularly in small individuals (Fig. 21E), except for smooth lateral glabellar, axial, and border furrows. Preglabellar field and preocular field with radially arranged caeca commencing from a subtransverse vessel which extends from the anterior ends of the palpebral lobes in a gentle arch around the front of the glabella.

Thorax unknown. Pygidial outline similar to a circular segment, length (sag.) ca 40 percent maximum width (tr.). Axis of $c a$ three-fourth pygidial length, tapering backward, width (tr.) at anterior ring $\mathrm{ca} 30$ percent maximum pygidial width; composed of 4 axial rings and a terminal axial piece, the posterior tip with a faint lunular lobe along the exterior rim . Pleural fields with $\mathrm{ca} 4$ pairs of pleural furrows, which terminate some distance from pygidial margin; anterior pleural furrow well developed, the others progressively less clearly impressed; interpleural furrow visible between first and second segment, then obsolescent or absent; pos- terior part of pleural field without clear furrows, but with low, obsolescent depressions close to the pygidial border; steeply rising towards posterior tip of pygisial axis and creating a poorly defined platform. Pygidial border obsolete, recognizable by absence of pleural furrows. Axial rings covered with fine granules and each ring with a pair of moderately coarse granules arranged in discrete rows. Pleurae covered with few irregularly spaced, medium sized granules.

Discussion. - Eoptychoparia pearylandica sp. nov. is known only from four quite well preserved cranidia and two additional fragments in the same samples, plus a well preserved pygidium. However, all specimens clearly characterize the new species and show the characteristics of Eoptychoparia Rasetti, 1955.

Eoptychoparia pearylandica differs from Eoptychoparia normalis Rasetti, 1955, the type species of Eoptychoparia from the Ville Guay Conglomerate of Bic near Lévis, Québec, in having narrower palpebral lobes in a slightly more anterior position, a slightly narrower (sag.) and less elevated anterior and posterior border, a slightly wider preglabellar field, a slightly less tapering glabella with a more subtruncate frontal lobe and a more pronounced occipital node.

Eoptychoparia angustifrons Rasetti, 1955, also from the Ville Guay Conglomerate of Bic near Lévis, differs in having a narrower glabella with a less subtruncate front, a slightly wider and more elevated anterior border, and broader palpebral lobes in a slightly more posterior position.

Eoptychoparia intermedia Rasetti, 1955, again from the Ville Guay Conglomerate of Grosses Roches near Lévis, differs in having a distinctly swollen and broader (sag.) anterior border, a slightly sunken median portion on the preglabellar field and palpebral lobes in a slightly more posterior position.

Eoptychoparia convexa Rasetti, 1963, another species from the Ville Guay Conglomerate of Québec, was found in boulders on the Island of Orléans. It differs, among other characters, in a greater overall convexity of the cephalon with a strongly vaulted glabella with a fairly well rounded front. The same species was described from eleven boulders in the Downes Point Member of the lowest part of the Cow Head Group of western Newfoundland (Young \& Ludvigsen 1989). This Zacanthoides gilberti fauna (= P. gibbus Zone) included pygidia which show a great similarity with those from the Løndal section, but differ in the less tapering axis and the absence of any recognizable furrows in the posterior part of the pleural fields.

Eokochaspis piochensis (Palmer \& Halley, 1979), originally described as Eoptychoparia piochensis, from the $\mathrm{C}$-Shale Member of the Pioche Formation (PlagiuraPoliella "Zone", basal Delamaran) of the Highland Range, 
Nevada, is based on imperfectly preserved type material, but has been subsequently described from the Eokochaspis nodosa Zone at the base of the Emigrant Formation of the Last Chance Range, eastern California (McCollum \& Sundberg 2007), the Comet Shale Member of the Pioche Formation in the Highland Range, Chief Range and Delamar Mountains, eastern Nevada (Sundberg \& McCollum 2000), and probably the Emigrant Formation of Split Mountain, western Nevada (Sundberg \& McCollum 2003). The glabella of Eokochaspis piochensis is certainly much more conical in outline than that of E. pearylandica and relatively slender, as it is characteristic for the species of Eokochaspis. In contrast to Eoptychoparia pearylandica, the anterior glabellar furrows of Eokochaspis piochensis originated close to the axial furrows. In addition, E. piochensis had fairly broad palpebral lobes and a sagittally narrower preglabellar field (see also Sundberg \& McCollum 2000).

Eoptychoparia manifesta Lazarenko, 1962 is a fairly frequent species from the Lermontovia dzevanovski-Paramicmacca petropavlovski and Anabaraspis splendens zones of the Olenek Uplift and the southeastern Prianabar regions, northern Siberian Platform (e.g. Sekten and Kuonamka formations, see Astashkin et al. 1991). It differs distinctly from the typical Laurentian species of Eoptychoparia in having a narrower glabella with only three lateral glabellar furrows, and a distinctly upturned and brim-like anterior border. In addition, it has wider (tr.) palpebral lobes than E. pearylandica.

Eoptychoparia striata Repina, 1964, described from the Solontsov "horizon" of the Kuznetsk Alatau, is clearly distinguished from the Laurentian species assigned to Eoptychoparia in having a relatively broad (tr.) glabella with a more or less rounded front; a narrow, groove-like anterior glabellar furrow from which the anterior border ascends to a brim-like blade; palpebral lobes which are longer than in the typical species of Eoptychoparia and develop anteriorly into the eye ridges; and an obviously stout occipital spine.

Eoptychoparia prominens Pegel, 1980 (in Vinkman et $a l ., 1980)$ from the Obrutchev "horizon" of the Tuva region in the Sayan-Altay Foldbelt shows a quite variable morphology which is atypical for Eoptychoparia. All of the figured material appears to have had a terminal occipital thorn, distinct anterolateral corners of the glabella, forwardly directed S3, a preglabellar field which is shorter than the anterior border, palpebral lobes in a quite posterior position, a fixigenae which tend to slope towards the glabella.

A number of species attributed to Eoptychoparia have been described from China, mostly from the South China platform. They include Eoptychoparia benxiensis Guo \& An, 1982, E. canida Nan \& Chang, 1982, E. connata Zhou, 1980 (in Zhang et al., 1980), E. gaodongensis Zhou, 1974 (in Lu et al., 1974), E. jinshaensis Zhou, 1974 (in Lu et al., 1974), E. nangaoensis Yuan, 1980 (in Zhang et al., 1980), E.? obscura Zhou, 1980 (in Zhang et al., 1980), E. taijianensis Lee, 1978, E. wutingensis (Chang, 1964) (originally described as Yuehsienszella wutingensis), and E. yunnanensis Zhou, 1980 (in Zhang et al., 1980). They all represent a certain clade of ptychoparioids with a basal set of morphological characteristics and resemble the Laurentian species of Eoptychoparia in this respect. However, only three lateral glabellar furrows can be seen in the Chinese species, with S3 directed forward from the axial furrows. Additionally, they are all distinguished from E. pearylandica by a sagittally narrower preglabellar field and distinctly broader (tr.) palpebral lobes.

Stratigraphy. - The material of Eoptychoparia pearylandica sp. nov. comes from the Løndal section (Fig. 6). Both sample horizons, GGU collections 225706 and 225707, are from just below the thick sandstone unit in the section. GGU collection 225706 represents a relatively fossiliferous horizon with Eoagnostus roddyi and the lowest occurrence of Protoryctocephalus arcticus in the section. A coeval sample from the same section, GGU collection 271750, yields Arthricocephalus cf. chauveaui. GGU collection 225707, a few metres upsection, is poorly fossiliferous, but yields the lowest occurrence of Lancastria cf. plana in the Løndal section.

\section{Genus Onchocephalus Resser, 1937}

Type species (by original designation). - Ptychoparia thia Walcott, 1917, from the Mt. Whyte Formation, Mount Bosworth, British Columbia, Canada.

Discussion. - Onchocephalus Resser, 1937, as generally viewed, belongs to the Eoptychoparia-Syspacephalus clade which is represented by genera with few morphological characteristics on a ptychoparioid body plan of generalized morphology. Diagnostic features are the highly convex glabella, a notable median swelling of the anterior border and corresponding shallow and poorly defined plectral swelling in front of the glabella, and sutures with a subparallel section from the anterior ends of the eyes. In all other aspects, the body plan of Onchocephalus agrees with that of Eoptychoparia.

Sundberg (2004), however, included species of Onchocephalus in a cladistic analysis and considered that they appear at three different places in the resulting cladogram. Onchocephalus depressus Rasetti, 1951 occurs next to an outgroup with Elrathina and Syspacephalus. Onchocephalus maior Rasetti, 1951 and O. fieldensis Rasetti, 1951 occur in the clade of miscellaneous cranidia adjacent to the Mexicella clade, whereas the type species of the 
genus, Onchocephalus thia (Walcott, 1917), occurs in an Amecephalus subclade. This apparent polyphyletic character suggests the need for a revision of the group; it can also be explained by the absence of data on the pygidial morphology and could partly be modified by a reweighting of characters.

It should be noted that Lochman (1947, p. 63) reviewed the type material and emphasized several characters which were not shown correctly in Walcott's (1917, pl. 12, fig. 6) retouched figure of the holotype of Ptychoparia thia. The problem has also been addressed by Palmer (1958), and Sundberg \& McCollum (2000) even suggested that the name Onchocephalus should be restricted to the type material of the type species. Hence, the new species described below is only tentatively placed under Onchocephalus.

\section{Onchocephalus? freucheni sp. nov.} Figure 22A-X

1997 Ptychoparella sp. A. - Blaker \& Peel, p. 124, figs $76.1-76.4,77.1-77.4,77.7,77.8,78.1-78.6$, 79.1-79.11 (only).

Holotype. - MGUH 23515, fairly complete carapace without librigenae (Fig. 22A, latex cast of external mould also figured by Blaker \& Peel 1997, fig. 76.2).

Type locality and type stratum. - Freuchen Land section (Fig. 4), Peary Land, North Greenland, Henson Gletscher Formation, horizon characterised by GGU collection 301344.

Paratypes. - Freuchen Land section (Fig. 4), GGU collection 298553: three cranidia with articulated partial or complete thorax, three cranidia and two librigenae under MGUH 23516-23519, MGUH 23536-23540); GGU col- lection 301344: cranidium with articulated partial or complete thorax under MGUH 23515, cranidium under MGUH 23520; GGU collection 301346: 15 cranidia under MGUH 23521-23535; GGU collection 301348: two unfigured cranidia under MGUH 29437 and 29438.

Derivatio nominis. - Named after Greenland explorer Peter Freuchen (1886-1957) whose name is enshrined in Freuchen Land.

Diagnosis. - Species tentatively placed under Onchocephalus with following characters in adult morphology: glabella with rounded anterolateral corners; anterior border moderately wide (sag.) and moderately convex; anterior border furrow moderately deep, with a slight backward swing to create a gentle median swelling of the anterior border; palpebral lobes of $c a 20$ percent cephalic length; fixigenae gently convex, of $c a 55$ percent maximum glabellar width.

Description of adult morphology. - Cranidium subtrapezoidal in outline, with strongly extending posterolateral portions. Ratio length to width $c a 0.55$.

Glabella transversely moderately to strongly convex, lateral profile gently convex in the posterior half, progressively sloping towards anterior; more or less equally tapering forward from occipital furrow to $S 4$ to about 60 to 65 percent maximum width; frontal lobe with rounded anterolateral corners and a shallow to subtruncate median portion, occasionally with feeble median indentation; length $\mathrm{ca} 65$ to 70 percent cephalic length, transverse width across L1 ca 45 percent transverse cranidial width across posterior tips of palpebral lobes. Four pairs of glabellar furrows, moderately well impressed near axial furrows, progressively less well impressed from S1 to S4 and fading towards midline; $\mathrm{S} 1$ directed backward from axial furrows and gently curved, shallow for most distance; S2 slightly

Figure 22. Onchocephalus? freucheni sp. nov., Henson Gletscher Formation, dorsal views of exterior unless otherwise stated. • A - holotype, almost complete carapace, latex cast of external mould, MGUH 23515 from GGU collection 301344, × 4.3. • B - paratype, cranidium with attached articulated thorax, MGUH 23516 from GGU collection 298553, $\times$ 4.5. $\bullet$ C - paratype, cranidium with attached articulated thorax, MGUH 23517 from GGU collection $298553, \times 5.7 . \cdot \mathrm{D}$ - paratype, cranidium with attached articulated partial thorax, MGUH 23518 from GGU collection $298553, \times 5 . \bullet \mathrm{E}-$ paratype, librigena, MGUH 23539 from GGU collection 298553, × 8.・F - paratype, librigena, MGUH 23540 from GGU collection 298553, $\times 7.5$. G - paratype, incomplete cranidium, MGUH 23521 from GGU collection 301346, × 4.5. $\bullet$ H - paratype, juvenile cranidium, internal mould, MGUH 23532 from GGU collection $301346, \times 7$. $・$ I - paratype, cranidium with attached partial thorax, latex cast from external mould, MGUH 23519 from GGU collection $298553, \times 5.5$. $\bullet J-$ paratype, cranidium, MGUG 23534 from GGU collection $301346, \times 6 . \bullet$ K - paratype, cranidium, partially exfoliated, MGUH 23523 from GGU collection 301346, $\times 5.5$. $\bullet$ L - paratype, juvenile cranidium, MGUH 23528 from GGU collection 301346, $\times 9$. $\bullet$ M - paratype, cranidium, MGUH 23529 from GGU collection 301346, $\times 8$. $\bullet$ N - paratype, cranidium, partly exfoliated, MGUH 23522 from GGU collection $301346, \times 5$. - O - paratype, juvenile cranidium, largely exfoliated, MGUH 23530 from GGU collection $301346, \times 8.5$. $\bullet P$ - paratype, cranidium, lateral view, MGUH 23527 from GGU collection $301346, \times 5$. $\bullet$ Q, R - paratype, cranidium, partly exfoliated, MGUH 23538 from GGU collection 298553 , left lateral and dorsal views, $\times 5$. $\bullet \mathrm{S}$ - paratype, juvenile cranidium, MGUH 23535 from GGU collection $301346, \times 7$. $\bullet$ T - paratype, juvenile cranidium, internal mould, MGUH 23524 from GGU collection $301346, \times 6$. $\bullet$ U, V - paratype, cranidium, slightly flattened and partly exfoliated, MGUH 23537 from GGU collection 298553, dorsal and left lateral views, $\times 5.5$. $\bullet$ W - paratype, juvenile cranidium, internal mould with remains of test, MGUH 23525 from GGU collection 301346, $\times 13 . \cdot \mathrm{X}$ - paratype, cranidium, internal mould, MGUH 23533 from GGU collection 301346, $\times$ 5; note distinct pattern of muscle insertions on glabella. 

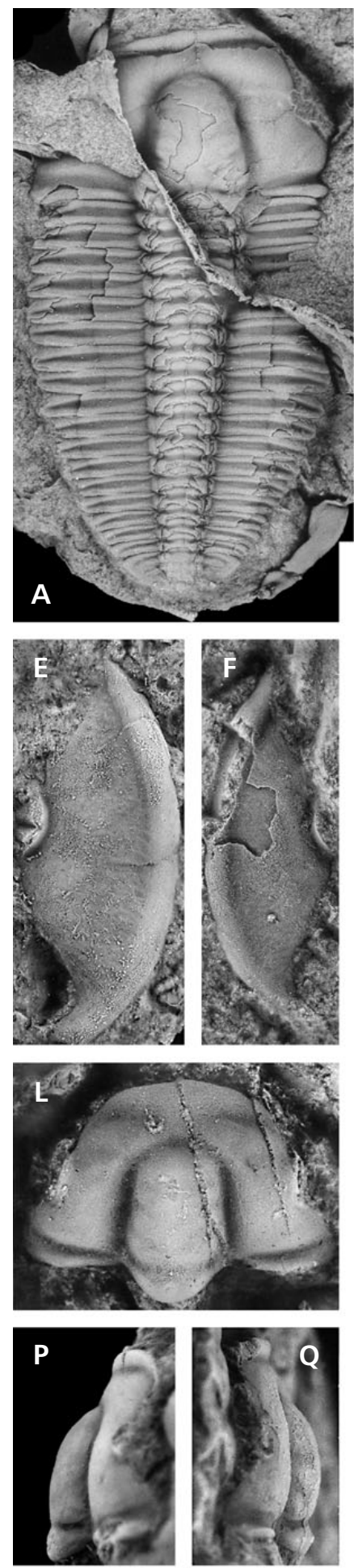
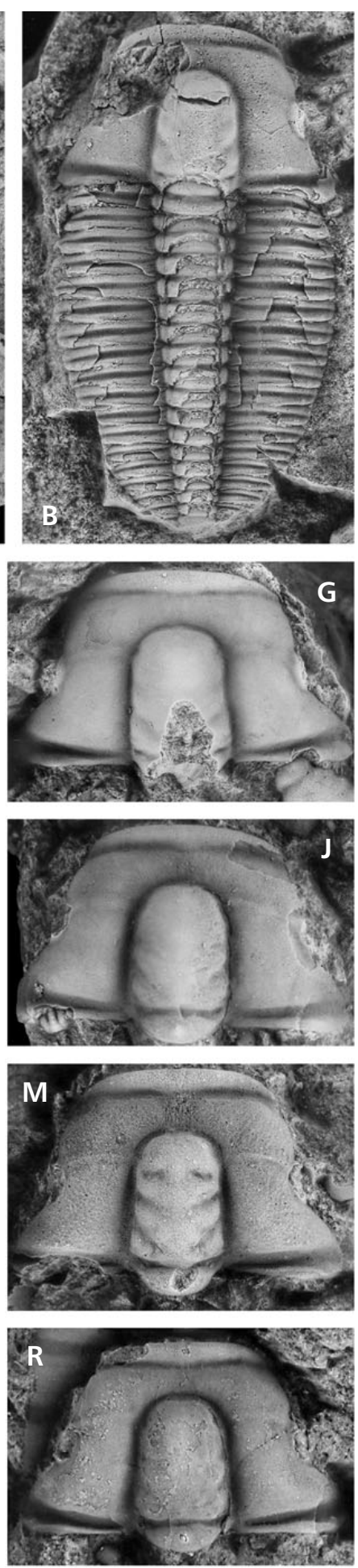
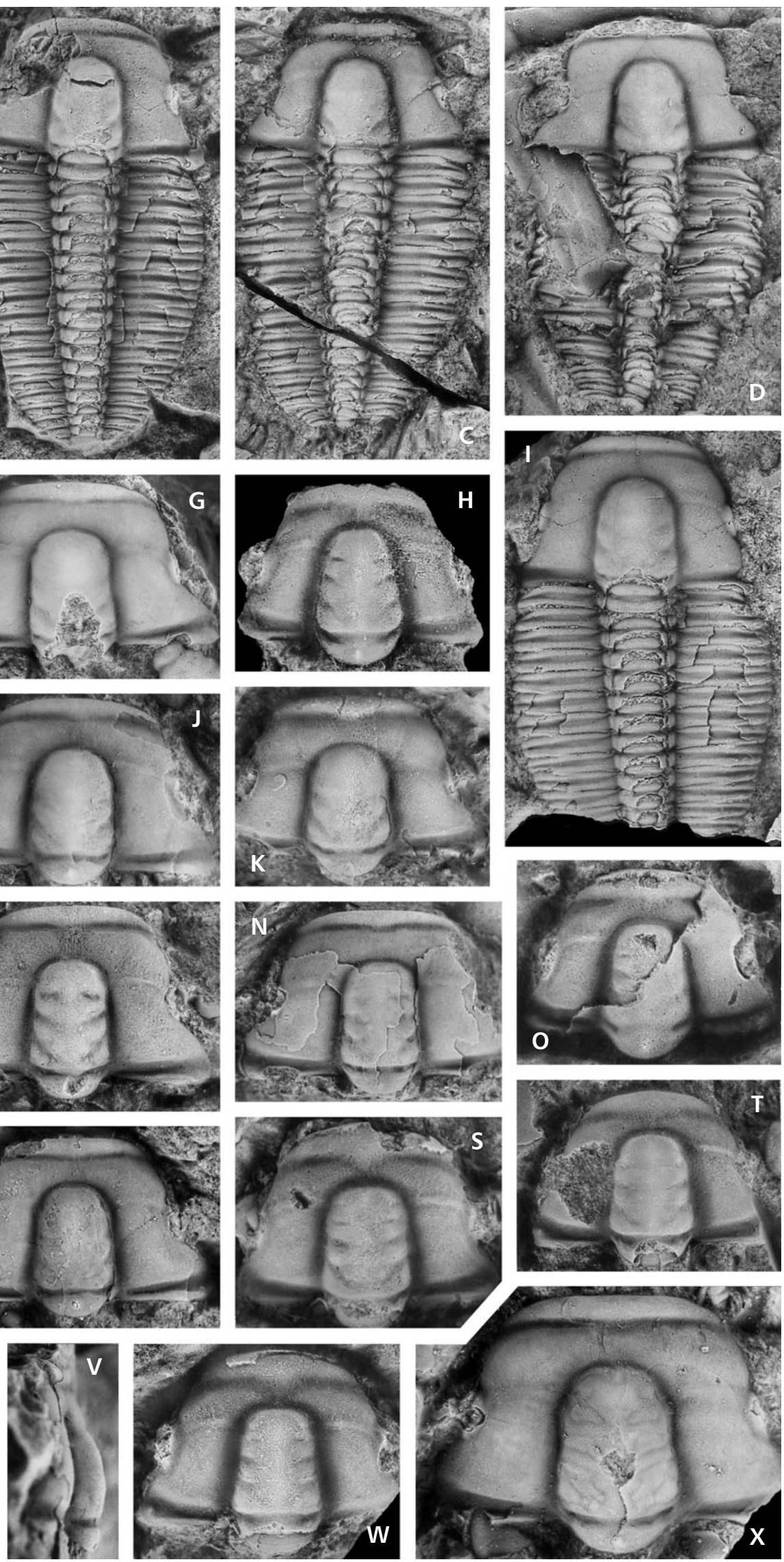
backward directed, shallow; S3 faint, slightly forward directed; S4 faint, forward directed and with weak curvature. Occipital furrow with slightly backward directed narrow and deep lateral sections and a wider somewhat shallower median section. Occipital ring with fairly equally curved margin, lateral portions narrow; sagittal length $\mathrm{ca} 12$ percent cephalic length; with prominent median node.

Axial furrows well incised and deep laterally, moderately deep in front of the glabella. Eye lobe short to moderately long, in adult individuals exsag. of $c a 20$ percent cephalic length (distinctly less in juveniles), oblique to axis, anterior end in transverse line with S3, posterior end about in transverse line with $\mathrm{S} 1$; palpebral lobe prominent, rises steeply from cheek, defined by shallow and narrow palpebral furrow, which is slightly curved adaxially near anterior end. Eye ridge form shallow elevated lobes directed inward and forward to axial furrow opposite immediately anterior to $\mathrm{S} 4$, with faint continuation to frontal lobe across deep axial furrow.

Fixigenae gently convex, moderately wide (tr.), transverse width between posterior ends of palpebral lobe and axial furrow ca 55 percent maximum glabellar width. Posterior area of fixigena extends into a considerably large and exsagittally relatively narrow, wing-like posterolateral projection.

Anterior border distinctly convex, moderately broad, growing from the suture to the sagittal line to more than double breadth (variably of $c a$ 11-17 percent cephalic length), typically with gentle median rearward extension; anterior margin with more or less equal gentle curvature in dorsal view, with slight dorsal bulge in anterior view. Anterior border furrow a moderately wide (sag. and exsag.) depression, with a median backward swing, which is strongly developed in juveniles and diminishes with growing size. Preglabellar field sagittally slightly narrower than anterior border when the median swelling is well expressed, slightly sunken in front of the glabella. Genal fields gently convex, exsag. broad, sloping towards anterior border furrow. Anterior branch of suture parallel from anterior ends of eyes, then curving inward in a gentle curvature and with a clear adaxial curvature after meeting the anterior border, cutting it very obliquely. Posterior border fairly narrow (exsag.), very narrow next to axial furrow, directed slightly posterolaterally with a gentle curvature and growing in breadth up to a fulcral point about one-fourth distance from posterolateral tips; distinctly convex. Posterior border furrow moderately wide (exsag.) and fairly deep, slightly shallower adaxially.

Surface of cranidium densely covered with small granules except for smooth lateral glabellar, axial, and border furrows. Preglabellar field and preocular field with fine radial caeca.

Librigena with gently curved lateral margin, continuous in narrowly rounded posterolateral corner of the cephalon without a genal spine. Ocular platform wide (tr.), gently convex. Lateral border gently convex, moderately wide, defined by shallow, mostly indistinct border furrow. Sutural margins reflect described courses and indicate narrow, moderately curved ocular suture. Surface of ocular platform with faint, slightly irregularly branched radial caeca (Fig. 22E).

Thorax of up to 17 segments in the present material. Axial rings of segments 3 to 17 of more-or-less uniform shape (sag. and exsag.), the length and width reduced progressively posteriorly. Transverse width of axial ring $\mathrm{ca}$ 25 percent overall width of the segment. Narrow (sag. and exsag.) articulating furrow with faint apodemal pit distally. Each ring has a faint lateral inflation indicating the attachment sites of ventral muscles. Pleurae widest (tr.) at segments 3 to 4 , decreasing progressively in width (tr.), becoming slightly more strongly backwardly directed in the posterior fifth of the thorax. Pleural furrows moderately wide, more or less straight or faintly s-shaped, fading short distance from pleural tips. Pleural ends developed as bluntly rounded tips with a faint subposterior kink. In anterior view, the pleurae show a distinct geniculation at $c a$ 60 percent of its transverse length from axial furrow, which corresponds with the articulating of adjacent segments by means of a fulcral point. As a result, the anterior flanks of the distant pleural portions have an almost flat articulating facet and the posterior margin of the distal pleural turns slightly forward to allow overlap of adjacent segments during inclination of the segments. First thoracic segment differs in having an axial ring the anterior margin of which swings backward considerable to allow a dorsal flexure of the cephalon against the thorax. Its pleurae have a particularly well developed fulcral point to fit into the socket of the cephalon's posterior border, and the distal pleura has a distinctly backward directed anterior margin and a distinct articulating facet. This configuration is repeated in a less distinct manner in the second thoracic segment.

Pygidium subsemielliptical in outline, length (sag.) ca 35 percent maximum width (tr.). Axis of $c a$ twothirds pygidial length, tapering backward, width (tr.) at anterior ring $c a$ two-fifth maximum pygidial width; composed of 3 axial rings and a terminal axial piece. Pleural fields with 3-4 pairs of pleural furrows, which terminate some distance from pygidial margin. Pygidial border obsolescent.

Surface covered with small to medium sized granules except for well developed furrows. Distinct pattern of muscle insertions marked on glabella of internal mould MGUH 23533 (Fig. 22X).

Ontogenetic and preservational differences. - The species apparently shows considerable morphologic variation (as pointed out by Blaker \& Peel 1997, p. 127, in discussing just GGU collection 301346) which is a result 
both of changes during ontogeny and preservational modification. Clear ontogenetic trends affect the following characters:

(1) The palpebral lobes grow with increased size from less than 15 to $\mathrm{ca} 20$ percent cephalic length. At the same time they turn from a slight to a distinctly oblique position and move progressively backwards.

(2) Juvenile cranidia have a distinct boss which develops from the anterior border and ideally show a complete median ridge to the glabellar front; in this respect they resemble Crassifimbra. The median swelling of the anterior border is sometimes difficult to see on specimens from shaly samples but is always detectable from the shallower sagittal part of the anterior border furrow. The thickening of the anterior border is also inconspicuous if the specimens are viewed from a slightly oblique anterior position.

(3) Juvenile cranidia show a subtruncate glabellar front, whereas adult individuals have more strongly rounded anterolateral corners of the glabella.

(4) The glabella in juveniles generally tapers more strongly than that in large specimens.

(5) Internal moulds show much better impressed lateral glabellar furrows than exterior surfaces of the test.

(6) The median swelling and the resulting boss are better visible on internal moulds than on the exterior.

(7) Internal moulds tend to show a faint median crest-line on the glabella which cannot be seen on the exterior.

Discussion. - Onchocephalus? freucheni sp. nov. is distinguished from nearly all of the species attributed to the genus in having a comparatively narrow (sag.) anterior border, a relatively shallow anterior border furrow, and a median swelling of the anterior border which is fairly moderately developed in adults. These differences indicate that $O$. ? freucheni is not a typical species of the genus, the ontogenetic development demonstrates that the species is placed within Onchocephalus with considerable qualification. It is rather obvious that the ontogenetic changes appear to indicate a trend in evolutionary development as suggested by Haeckel's recapitulation theory.

The most similar previously described species was introduced as Elrathina antiqua Palmer in Palmer \& Halley, 1979 from the Ogygopsis faunula of the "Albertella" Zone of the Belted Range, Nevada; this is tentatively transferred to Onchocephalus herewith. This species is distinguished by its sagittally shorter preglabellar, a slightly more subtruncate glabellar frontal lobe and a broader palpebral lobes as well as a broader axis in the pygidium. The holotype (Palmer \& Halley 1979, pl. 15, fig. 1) is a nearly complete carapace of an adult specimen with 16 segments. Known only from limited material, Onchocephalus? antiquus merits a redescription to clarify whether all of the specimens figured by Palmer (in Palmer \& Halley 1979, pl. 15, figs 1-3) indeed belong to the same species (see differences in, e.g., the anterior border and the inclination of the palpebral lobes).

In fact, a majority of the species once assigned to Onchocephalus were transferred to other genera based on more or less robust characters, or just excluded from Onchocephalus. This includes Nyella skapta (Walcott, 1917), Antagmus fieldensis (Rasetti, 1951), Antagmus maior (Rasetti, 1951), Onchocephalus depressus Rasetti, 1951 and Onchocephalus supremus Repina, 1960 (in Khalfin, 1960). Onchocephalus depressus, for example, from the Plagiura-Kochaspis fauna of the Mount Whyte Formation of Mount Field, British Columbia, is imperfectly known and appears to be atypical for Onchocephalus. In any case, it distinctly differs from $O$.? freucheni in characters such as the wider (tr.) and more strongly tapering glabella, and a broader (sag. and exsag.) anterior border.

Onchocephalus supremus Repina, 1960 (in Khalfin, 1960) was described from the Solontsov "horizon" of the Kusnetsk Alatau and is distinguished from O.? freucheni and species typical for Onchocephalus in having three well impressed lateral glabellar furrows, a truncate glabellar front, quite convex fixigenae, a narrow preglabellar field, and a bulging anterior border.

Onchocephalus sulcatus Rasetti, 1955 from the Ville Guay Formation at Grosses Roches, Québec, has a clearly tapering glabella with a subtruncate to gently curved frontal lobe and a slightly swollen, broader (sag. and exsag.) anterior border, a relatively narrow (sag.) preglabellar field which is sunken medially, and narrower fixigenae. Onchocephalus? limbatus Rasetti, 1963, from the Ville Guay Formation at Ville Guay, Québec, has a swelling which divides the anterior border furrow longitudinally. Onchocephalus ornatus Rasetti, 1963, from the Ville Guay Formation at Bic, Québec, differs from O.? freucheni on account of its more strongly tapering glabella and distinct fine granulation.

Onchocephalus buelnaensis Lochman, 1952 and O. mexicanus Lochman, 1952 were described from the Buelna Formation (upper Olenellus Zone) of the Proveedora Hills of the Caborca area, Sonora. Both have a glabella which distinctly tapers forward, a slightly swollen and hence broader (sag.) anterior border, and pygidia with clearly visible interpleural furrows, an anterior margin which swings distinctly backward from the axis, and the posterior end of the rhachis close to the posterior margin.

The type species, Onchocephalus thia (Walcott, 1917), is known only from poorly preserved specimens and is in need of a redescription. Walcott (1917, pl. 12, fig. 6) appears to have combined specimens from different taxa to produce his only figure (see Rasetti 1951). However, the 
type differs from $O$. ? freucheni at least in possessing a more strongly tapering glabella, slightly wider fixigenae, and a distinctly broader (sag.) preglabellar field.

Onchocephalus? freucheni is the best represented and most frequent ptychoparioid trilobite in the Henson Gletscher Formation. Its detailed description may be seen as a response to the call by Blaker \& Peel (1997, p. 124) "...for more information based on complete trilobite exoskeletons..." if the taxonomic problems associated with ptychoparioid classification are to be resolved. Onchocephalus? freucheni is apparently restricted to the Freuchen Land section (Fig. 4) where it occurs only in a narrow stratigraphic interval above the sandstone unit. Similar, but not identical, specimens occur in the Løndal and Fimbuldal sections.

Syspacephalus Resser, 1938, another candidate genus for the placement of O.? freucheni and similar species, has been synonymized with Elrathina Resser, 1937 by some authors such as Robison (1976) and Babcock (1994). However, Syspacephalus awaits a careful revision before this synonymy can be accepted. In any case, the shape of the glabella with nearly subparallel sides and the short palpebral lobes resembles species traditionally placed under Syspacephalus rather than typical species of Onchocephalus. Nevertheless, O.? freucheni shows the narrower fixigenae and particularly narrower and shorter posterior area of the fixigena, as well as a wider glabella, diagnostic to differentiate Onchocephalites from Syspacephalus.

\section{Acknowledgements}

All material described from the Henson Gletscher Formation by Mark R. Blaker and John S. Peel and in the present paper was collected during expeditions to North Greenland under the auspices of the Geological Survey of Greenland (now a part of GEUS, the Geological Survey of Denmark and Greenland). Mark Blaker, Jon Ineson, Peter Frykman and Stephen Wright assisted Peel in collecting specimens in the field during 1978, 1979, 1984, 1985 and 2006. Jon Ineson (Copenhagen) is further acknowledged for making available stratigraphic logs of the Henson Gletscher Formation and for sharing his knowledge and wide experience of North Greenland Cambrian geology.

We are also indebted to Peng Shanchi (Nanjing) for translating Chinese texts from the literature, thus making important information accessible to us. Fred A. Sundberg (Show Low, AZ) provided an extremely helpful critical review, as did Zhang Xinliang (Xi'an). Elena B. Naimark (Moscow), Yuan Jinliang (Nanjing), Fred A. Sundberg (Show Low, AZ), Zhao Yuanlong (Guiyang), and Igor V. Korovnikov (Novosibirsk) all offered information on various species and their occurrences in Siberia, South China, and western Laurentia, respectively.

Ongoing financial support from the Swedish Research Council (Vetenskapsrådet) through grants to Peel is gratefully acknowledged.

\section{References}

Astashin, V.A., Pegel, T.V., Shabanov, Y.Y., Sukhov, S.S., Sundukov, V.M., Repina, L.N., RoZANOV, A.Y. \& ZhuRAVLEV, A.Y. 1991. The Cambrian System on the Siberian Platform; correlation chart and explanatory notes. International Union of Geological Sciences, Publication 27, 1-133.

BАвСоCK, L.E. 1994. Systematics and phylogenetics of polymeroid trilobites from the Henson Gletscher and Kap Stanton formations, North Greenland. Bulletin Grønlands Geologiske Undersøgelse 169, 79-127.

BАвСоск, L.E. \& PeEL, J.S. 2007. Palaeobiology, taphonomy, and stratigraphic significance of the trilobite Buenellus from the Sirius Passet Biota, Cambrian of North Greenland. Memoirs of the Association of Australasian Palaeontologists 34, 401-418.

Banerjee, D.M., Schidlowski, M., Siebert, F. \& Brasier, M.D. 1997. Geochemical changes across the Proterozoic-Cambrian transition in the Durmala phosphorite mine section, Mussoori Hills, Garhwal Himalaya, India. Palaeogeography, Palaeoclimatology, Palaeoecology 132, 183-194. DOI 10.1016/S0031-0182(97)00060-6

BednarczyK, W. 1970. Trilobites Fauna [sic] of the Lower Paradoxides oelandicus Stage from the Brzechów Area in the Western Part of the Świętokrzyskie Mts. Bulletin de l'Académie Polonaise des Sciences, Série des sciences géologiques et géographiques 18, 29-35.

Bengtson, S., Conway Morris, S., Cooper, B.J., Jell, P.A. \& Runnegar, B.N. 1990. Early Cambrian fossils from South Australia. Memoir of the Association of Australasian Palaeontologists 9, 1-364.

Bergeron, J.N. 1899. Étude de quelques trilobites du Chine. Bulletin de la Société Géologique du France, Series 3, 27, 181-207.

BlaKeR, M.R. 1986. Notes on the trilobite faunas of the Henson Gletscher Formation (Lower and Middle Cambrian) of central North Greenland. Rapport Grønlands Geologiske Undersøgelse 132, 65-73.

BlaKeR, M.R. 1991. Early Cambrian trilobites from North Greenland. 286 pp. Unpublished Ph.D. thesis, University of Keele, U.K.

Blaker, M.R. \& Peel, J.S. 1997. Lower Cambrian trilobites from North Greenland. Meddelelser om Grønland, Geoscience 35, $1-145$.

BRASIER, M.D. 1985. Evolutionary and geological events across Precambrian-Cambrian boundary. Geology today, Sept-Oct 1985, 141-146.

BRASIER, M.D. 1991. Nutrient flux and the evolutionary explosion across the Precambrian-Cambrian boundary interval. Historical Biology 5(2-4), 85-93.

Brasier, M.D. 1992. Paleoceanography and changes in the biological cycling of phosphorus across the Precambrian-Cambrian boundary, 483-523. In LiPPS, J.H. \& SignOR, P.W. (eds) Origin and Early Evolution of the Metazoa. Plenum Press, New York. 
BRASIER, M.D. 1994. Towards a carbon isotope stratigraphy of the Cambrian System: potential of the Great Basin succession, 341-350. In HaILwood, E.A. \& KIDD, R.B. (eds) High Resolution Stratigraphy. Geological Society Special Publication 70.

Brasier, M.D., Anderson, M.M. \& Corfield, R.M. 1992. Oxygen and carbon isotope stratigraphy of early Cambrian carbonates in southeastern Newfoundland and England. Geological Magazine 129(3), 265-279.

DOI 10.1017/S001675680001921X

Brasier, M.D., Khomentovsky, V.V. \& Corfield, R.M. 1993. Stable isotopic calibration of the earliest skeletal fossil assemblages in eastern Siberia (Precambrian-Cambrian boundary). Terra Nova 5, 225-232.

Brasier, M.D., Corfield, R.M., Derry, L.A., Rozanov, A.Y. \& Zhuravlev, A.Y. 1994a. Multiple $\delta^{13} \mathrm{C}$ excursions spanning the Cambrian explosion to the Botomian [sic] crisis in Siberia. Geology 22(5), 455-458.

Brasier, M.D., Rozanov, A.Yu., Zhuravlev, A.Yu., Corfield, R.M. \& DERRY, L.A. 1994b. A carbon isotope reference scale for the Lower Cambrian succession in Siberia: report of IGCP Project 303. Geological Magazine 131(6), 767-783. DOI 10.1017/S0016756800012851

Brasier, M.D., Magaritz, M., Corfield, R., Luo, H.L, Wu, X.C., Ouyang, L., JiAnG, Z.W., Hamdi, B., He, T.G. \& Fraser, A.G. 1990. The carbon- and oxygen-isotope record of the Precambrian-Cambrian boundary interval in China and Iran and their correlation. Geological Magazine 127(4), 319-332. DOI 10.1017/S0016756800014886

Brasier, M.D. \& SuKhov, S.S. 1998. The falling amplitude of carbon isotopic oscillations through the Lower to Middle Cambrian; northern Siberia data. Canadian Journal of Earth Sciences 35(4), 353-373.

BRøGGER, W.C. 1882. Paradoxides Ölandicus-nivået ved Ringsaker i Norge. Geologiska Föreningens i Stockholm Förhandlingar 74, VI(4), 143-148.

BRøGGER, W.C. 1886. Om alderen af Olenelluszonen i Nordamerika. Geologiska Föreningens $i$ Stockholm Förhandlingar 101, VIII(3), 182-213.

Chernysheva, N.E. 1960a. Trilobita, 17-194. In Orlov, Y.A. (ed.) Fundamentals of Paleontology. Vol. 8, Arthropoda trilobites and crustaceans. 515 pp. Akademiya Nauk SSSR, Moscow. [in Russian]

Chernysheva, N.E. 1960b. New early Palaeozoic trilobites of eastern Siberia and Kazakhstan, 254-255. In MARKOvSKIY, B.P. (ed.) New species of fossil plants and invertebrates of the USSR, part 2. VSEGEI, Moscow. [in Russian]

Chernysheva, N.E. 1962. Kembriyskie trilobity semeystva Oryctocephalidae [Cambrian trilobites of the family Oryctocephalidae], 3-52. In Shvedov, N.A. (ed.) Problemy neftegazonosnosti Sovetskoy Arktiki. Paleontologiya i biostratigrafiya 3. Trudy Nauchno-issledovatel'skiy institut geologii Arktiki (NIIGA) 127(3). Gostoptekhizdat, Leningrad.

Chernysheva, N.E. (ed.) 1971. Amginskiy yarus Altae-Sayanskoy oblasti. Trudy Sibirskoy nauchno-issledovatel'skiy institut geologii, geofiziki i mineral'nogo syr'ya (SNIIGGiMS), Serya paleontologiya i stratigrafiya III. 267 pp. Zapadno-Sibirskoe nizhnoe izdatel'stvo, Novosibirsk.

Conway Morris, S., Peel, J.S., Higgins, A.K., Soper, N.J. \& DAVIS, N.C. 1987. A Burgess Shale-like fauna from the Lower Cambrian of Greenland. Nature 326, 181-183.

DOI $10.1038 / 326181 \mathrm{a} 0$

DeMOKIDOv, K.K. \& LAZARENKO, N.P. 1964. Stratigrafiya verkhnego dokembriya i kembriya i nizhnekembriyskie trilobity severnoy chasti Sredney Sibiri i ostrovov Sovetskoy Arktiki. Trudy nauchno-issledovatel'skogo instituta geologii arktiki (NIIGA) 137. 286 pp. Nedra, Moscow.

Derry, L.A., Brasier, M.D., Corfield, R.M., Rozanov, A.Y. \& Zhuravlev, A.Y. 1994. Sr and C isotopes in Lower Cambrian carbonates from the Siberian craton: A paleoenvironmental record during the 'Cambrian explosion'. Earth and Planetary Science Letters 128, 671-681.

DOI 10.1016/0012-821X(94)90178-3

Donnelly, T.H., Shergold, J.H. \& Southgate, P.N. 1988. Anomalous geochemical signals from phosphatic Middle Cambrian rocks in the southern Georgina Basin, Australia. Sedimentology 35, 549-570.

Ebneth, S., Shields, G.A., Veizer, J., Miller, J.F. \& Shergold, J.H. 2001. High-resolution strontium isotope stratigraphy across the Cambrian-Ordovician transition. Geochimica et Cosmochimica Acta 65, 2273-2292.

Elicki, O. \& GEYER, G. submitted. The Cambrian trilobites of Jordan - taxonomy, systematic and stratigraphic significance. Acta Geologica Polonica.

FLeTCHER, T.P. 1972. Geology and Lower to Middle Cambrian trilobite faunas of southwest Avalon, Newfoundland. Part Two. 295 pp. Unpublished Ph.D. thesis, University of Cambridge.

FLETCHER, T.P. 1999. Significant trilobites in the basal beds of a Cambrian stage corresponding to the Amga Stage of Siberia, 55-56. In PALmer, A.R. (ed.) Laurentia 99. $5^{\text {th }}$ Field Conference of the Cambrian Stage Subdivision Working Group, International Subcommission on Cambrian Stratigraphy. Abstracts. Institute for Cambrian Studies, Boulder, CO.

FLeTCHER, T.P. 2001. Arthricocephalus chauveaui Bergeron - a key species for the correlation of a global stage boundary, 257-260. In PenG, S.C., BABcock, L.E. \& ZhU, M.Y. (eds) Cambrian System of South China. Palaeoworld 13.

FLeTCHER, T.P. 2003. Ovatoryctocara granulata: the key to a global Cambrian stage boundary and the correlation of the olenellid, redlichiid and paradoxidid realms. Special Papers in Palaeontology 70, 73-102.

FLeTCheR, T.P. 2006. Bedrock geology of the Cape St. Mary's Peninsula, southwest Avalon Peninsula, Newfoundland. Government of Newfoundland and Labrador, Geological Survey, Department of Natural Resources, St. John's, Report 06-02, $1-117$.

FLeTChER, T.P. 2007. The base of Cambrian Series 3: the global significance of key oryctocephalid trilobite ranges in the Kaili Formation of South China. Memoirs of the Association of Australasian Palaeontologists 33, 29-33. 
Fletcher, T.P. \& Rushton, A.W.A. 2007. The Cambrian Fauna of the Leny Limestone, Perthshire, Scotland. Earth and Environmental Science Transactions of the Royal Society of Edinburgh 98, 199-218.

Geyer, G. 1988. Agnostida aus dem höheren Unterkambrium und dem Mittelkambrium von Marokko. Teil 2: Eodiscina. Neues Jahrbuch für Geologie und Paläontologie, Abhandlungen 177(1), 93-133.

Geyer, G. 1990a. Revised Lower to lower Middle Cambrian biostratigraphy of Morocco. Newsletters on Stratigraphy 22(2/3), 53-70.

Geyer, G. 1990b. Die marokkanischen Ellipsocephalidae (Trilobita: Redlichiida). Beringeria 3, 3-363.

GEYER, G. 1998. Intercontinental, trilobite-based correlation of the Moroccan early Middle Cambrian. Canadian Journal of Earth Sciences 35, 374-401.

Geyer, G. 2005. The base of a revised Middle Cambrian: are suitable concepts for a series boundary in reach? Geosciences Journal 9, 81-99. DOI 10.1007/BF02910571

Geyer, G. \& Landing, E. 1995. The Cambrian of the Moroccan Atlas region, 7-46. In GeYer, G. \& LANDing, E. (eds) MOROCCO '95 - the Lower-Middle Cambrian standard of western Gondwana. Beringeria Special Issue 2.

Geyer, G. \& Landing, E. 2001. Middle Cambrian of Avalonian Massachusetts: stratigraphy and correlation of the Braintree trilobites. Journal of Paleontology 75, 116-135.

DOI 10.1666/0022-3360(2001)075<0116:MCOAMS >2.0.CO;2

Geyer, G. \& Landing, E. 2004. A unified Lower-Middle Cambrian chronostratigraphy for West Gondwana. Acta Geologica Polonica 54, 179-218.

Geyer, G., Popp, A., Weidner, T. \& Förster, L. 2004. New Lower Cambrian trilobites from Pleistocene erratic boulders of northern Germany and Denmark and their bearing on the intercontinental correlation. Paläontologische Zeitschrift 78, $127-135$.

Geyer, G. \& Landing, E. 2006. Ediacaran-Cambrian depositional environments and stratigraphy of the western Atlas regions, 47-120. In Geyer, G. \& Landing, E. (eds) Morocco 2006 - Ediacaran-Cambrian depositional environments and stratigraphy of the western Atlas regions. UCL Maghreb Petroleum Research Group, Infracambrian / Early Palaeozic Field Guide Series 1 and Beringeria Special Issue 6.

Geyer, G. \& Shergold, J.H. 2000. The quest for internationally recognized divisions of Cambrian time. Episodes 23(3), 188-195.

Guo, H.J. \& AN, S.L. 1982. Lower Cambrian trilobites of the Benxi area, Liaoning. Acta Palaeontologica Sinica 21(6), 615-631. [in Chinese with English abstract]

Guo, Q.J., Strauss, H., Liu, C.Q., ZhaO, Y.L., Pi, D.H., Fu, P.Q., Zhu, L.J. \& YANG, R.D. 2005. Carbon and oxygen isotopic composition of Lower to Middle Cambrian sediments at Taijiang, Guizhou Province, China. Geological Magazine 142, 723-733. DOI 10.1017/S0016756805001202

Guo, Q.J., Strauss, H., Liu, C.Q., Zhao, Y.L., Yang, X.L., Peng, J. \& YANG, H. 2010a. A negative carbon isotope excursion de- fines the boundary from Cambrian Series 2 to Cambrian Series 3 on the Yangtze Platform, South China. Palaeogeography, Palaeoclimatology, Palaeoecology 285, 143-151.

DOI 10.1016/j.palaeo.2009.11.005

Guo, Q.J., Strauss, H., Liu, C.Q., Zhao, Y.L., Yang, X.L., Peng, J. \& YAnG, H. 2010b. Corrigendum to "A negative carbon isotope excursion defines the boundary from Cambrian Series 2 to Cambrian Series 3 on the Yangtze Platform, South China" [Palaeogeography, Palaeoclimatology, Palaeoecology 285 (2010) 143-151]. Palaeogeography, Palaeoclimatology, Palaeoecology 288, 118.

DOI 10.1016/j.palaeo.2010.01.022

HALL, J. 1860. Note upon the trilobites of the shales of the Hudson River Group in the town of Georgia, Vermont. New York State Cabinet of Natural History Annual Report 13, 113-119.

Higgins, A.K., Ineson, J.R., Peel, J.S., Surlyk, F. \& Sønderholm, M. 1991. Lower Palaeozoic Franklinian Basin of North Greenland, 71-139. In Peel, J.S. \& Sønderholm, M. (eds) Sedimentary basins of North Greenland. Bulletin Grønlands Geologiske Undersøgelse 160.

Hopkins, M.J. \& WeBster, M. 2009. Ontogeny and geographic variation of a new species of the corynexochine trilobite Zacanthopsis (Dyeran, Cambrian). Journal of Paleontology 83(4), 524-547. DOI 10.1666/08-102R.1

Hough, M.L., Shields, G.A., Evans, L.Z., Strauss, H. \& MaCKENZIE, S. 2006. A major sulphur isotope event at c. $510 \mathrm{Ma}$ : a possible anoxic-extinction-volcanism connection during the Early-Middle Cambrian transition? Terra Nova 18, 257-263.

HutChinson, R.D. 1962. Cambrian stratigraphy and trilobite faunas of southeastern Newfoundland. Bulletin of the Geological Survey of Canada 88, I-IX + 1-156.

Ineson, J.R. \& PeEL, J.S. 1997. Cambrian shelf stratigraphy of North Greenland. Geology of Greenland Survey Bulletin 173, $1-120$.

Ineson, J.R. \& PeEL, J.S. 2011. Geological and depositional setting of the Sirius Passet Lagerstätte (early Cambrian), North Greenland. Canadian Journal of Earth Sciences 48, 1259-1281. DOI 10.1139/e11-018

Jell, P.A. \& Hughes, N.C. 1997. Himalayan Cambrian trilobites. Special Papers in Palaeontology 58, 1-113.

Khalfin, L.L. (ed.) 1960. Biostratigrafiya paleozoya SayanoAltayskoy gornoy oblasti. Tom 1. Trudy Sibirskoy nauchnoissledovatel'skiy institut geologii, geofiziki i mineral'nogo syr'ya (SNIIGGiMS) 19. 497 pp. Novosibirsk.

Korovnikov, I.V. 2001. Lower and Middle Cambrian Boundary and trilobites from northeast Siberian Platform, 270-275. In Peng, S.C., BABCock, L.E. \& Zhu, M.Y. (eds) The Cambrian System of South China. Palaeoworld 13.

Kruse, P.D., Laurie, J.R. \& Webby, B.D. 2004. Cambrian geology and palaeontology of the Ord Basin. Memoirs of the Association of Australasian Palaeontologists 30, 1-58.

LANDING, E. 1992. Precambrian-Cambrian Boundary GSSP, SE Newfoundland: Biostratigraphy and Geochronology. Bulletin of Liason of the Subcommission on Geochronology 11, 6-8. 
LANDING, E. 2007. Ediacaran-Ordovician of East Laurentia-Geologic Setting and Controls on Deposition along the New York Promontory Region, 5-24. In LANDing, E. (ed.) S.W. Ford Memorial Volume: Ediacaran-Ordovician of East Laurentia. New York State Museum Bulletin 510.

Landing, E., Franzi, D.A., Hagadorn, J.W., Westrop, S.W., KröGER, B. \& DAwson, J.C. 2007. Cambrian of East Laurentia: Field Workshop in Eastern New York and Western Vermont, 25-71. In LANDing, E. (ed.) S.W. Ford Memorial Volume: Ediacaran-Ordovician of East Laurentia. New York State Museum Bulletin 510.

Landing, E., Geyer, G. \& Bartowski, K.E. 2002. Latest Early Cambrian small shelly fossils, trilobites, and Hatch Hill dysaerobic interval on the Québec continental slope. Journal of Paleontology 76, 287-305.

DOI 10.1666/0022-3360(2002)076<0287:LECSSF>2.0.CO;2

Landing, E., Geyer, G. \& Heldmaier, W. 2006. Distinguishing eustatic and epeirogenic controls on Lower-Middle Cambrian boundary successions in West Gondwana (Morocco and Iberia). Sedimentology 53, 899-918.

Landing, E. \& Westrop, S.R. 1996. Upper Lower Cambrian Depositional Sequence in Avalonian New Brunswick. Canadian Journal of Earth Sciences 33, 404-417.

LANE, P.D., Blaker, M.R. \& Zhang, W.T. 1988. Redescription of the Early Cambrian trilobite Arthricocephalus chauveaui Bergeron, 1899. Acta Palaeontologica Sinica 27, 553-560.

LaZARENKo, N.P. 1958. [On the discovery of Bathynotus in the Cambrian deposits of northern Siberia Platform]. Collected articles on paleontology and biostratigrophy of the Scientific Research Institute of Geology of Arctic 8, 15-19.

LAZARENKO, N.P. 1962. Novye nizhnekembriyskie trilobity Sovetskoyj Arktiki [New Lower Cambrian trilobites from the Soviet Arctic], 29-78. In Shvedov, N.A. (ed.) Sbornik statey po paleontologii i biostratigrafii, Institut geologii Arktiki 29. NIIGA, Leningrad.

Lermontova, E.V. 1940. VI Tip - Arthropoda, 112-157. In Vologdin, A. (ed.) Atlas rukovodyashchikh form iskopaemykh faun SSSR. 1. Kembriy. Gosgeoltekhizdat, Moscow \& Leningrad.

LERMONTOVA, E.V. 1951. Nizhnekembriyskie trilobity i brakhiopody Vostochnoy Sibiri. Trudy Vsesoyuznogo nauchnoissledovatel'skogo geologicheskogo instituta (VSEGEI). 218 pp. Gosgeolizdat, Moscow.

Lin, J.P. 2009. Review of the depositional environment of the Kaili Formation (Cambrian Series 2-3 boundary interval: China). Memoirs of the Association of Australasian Palaeontologists 37, 131-149.

LiN, J.P. 2010. Preliminary study of a negative carbon isotopic excursion in the middle Kaili Formation (Cambrian series 2-3) at the Miaopanbo section, Guizhou, China, 15. In FATKA, O. \& Budil, P. (eds) The $15^{\text {th }}$ Field Conference of the Cambrian Stage Subdivision Working Group, International Subcommission on Cambrian Stratigraphy. Abstracts and Excursion Guide, Prague, Czech Republic and south-eastern Germany. Czech Geological Survey, Prague.
LIN, J.P. 2011. Confirmation of a negative carbon istopic excursion in the middle Kaili Formation (Cambrian Series 2-3), Guizhou, China, 290. In Hollingsworth, J.S., SundBerg, F.A. \& FosTER, J.R. (eds) Cambrian stratigraphy and paleontology of northern Arizona and southern Nevada. The $16^{\text {th }}$ Field Conference of the Cambrian Stage Subdivision Working Group, International Subcommission on Cambrian Stratigraphy, Flagstaff, Arizona, and southern Nevada, United States. Museum of Northern Arizona Bulletin 67.

Lin, T.R. \& JAGO, J.B. 1993. Xystridura and other early Middle Cambrian trilobites from Yaxian, Hainan Province, South China. Transactions of the Royal Society of South Australia 117, 141-152.

Lindsay, J.F., Kruse, P.D., Green, O.R., Hawkins, E., Brasier, M.D., Cartlidge, J. \& Corfield, R.M. 2005. The Neoproterozoic-Cambrian record in Australia: a stable isotope study. Precambrian Research 143, 113-133.

Lochman, C. 1947. Analysis and revision of eleven Lower Cambrian trilobite genera. Journal of Paleontology 21(1), $59-71$.

Lochman, C. 1952. Trilobites in Cambrian stratigraphy and paleontology near Caborca, northwestern Sonora, Mexico. Smithsonian Miscellaneous Collections 119, 60-188.

Lu, Y.H. 1963. Supplementary notes on the Cambrian stratigraphy of China. Acta Geologica Sinica 1963(4), 314-326. [in Chinese with English summary]

Lu, Y.H., Zhang, W.T., Zhu, Z.L., Chen, Y.Y. \& Xiang, L.W. 1965. Fossils of each group of China. Chinese trilobites. 766 pp. Science Publication Company, Beijing. [in Chinese]

Lu, Y.H., Chang, W.T., Chien, Y.Y., Chu, C.L., Lin, H.L., Zhou, Z.Y., Qian, Y., Zhang, S.G. \& Yuan, J.L. 1974. Cambrian trilobites, 82-107. In NANJing Institute of GeOlogy and Palaeontology (ed.) Handbook of Stratigraphy and Palaeontology of southwest China. Science Press, Beijing. [in Chinese with English summary]

Luo, H.L., Li, Y., Hu, S.X., Fu, X.P., Hou, S.G., You, T., Pang, J.Y. \& Liu, Q. 2007. On the genus Megapalaeolenus Chang, 1966. Acta Palaeontologica Sinica 46(3), 314-326.

Luo, H.L., Hu, S.X., Hou, S.G., GaO, H.G., Zhan, D.Q. \& Li, W.C. 2009. Cambrian stratigraphy and trilobites from Southeastern Yunnan, China. 252 pp. Yunnan Science and Technology Press, Kunming. [in Chinese with English summary]

Maxey, G.B. 1958. Lower and Middle Cambrian stratigraphy in northern Utah and southeastern Idaho. Bulletin of the Geological Society of America 69(6), 647-688.

McCollum, L.B. \& Sundberg, F.A. 2002. Correlation of the Lower-Middle Cambrian boundary interval in the Circum-Pacific region based on oryctocephalid trilobites. First International Palaeontological Congress, Geological Society of Australia Abstracts 68, 242-243.

McCollum, L.B. \& Sundberg, F.A. 2007. Cambrian trilobite biozonation of the Laurentian Delamaran Stage in the southern Great Basin, U.S.A.: Implications for global correlations and defining a Series 3 global boundary stratotype. Memoirs of the Association of Australasian Palaeontologists 34, 147-156. 
McNamara, K., Feng, Y. \& Zhou, Z. 2003. Ontogeny and heterochrony in the oryctocephalid trilobite Arthricocephalus from the Early Cambrian of China. Special Papers in Palaeontology 70, 103-126.

Montañez, I.P., Osleger, D.A., Mack, L.E. \& Musgrove, M. 2000. Evolution of the Sr and C isotope composition of Cambrian oceans. GSAToday 10(5), 1-7.

Montañez, I.P., Nest, D., GragG, K., McCollum, L.B., McCollum, M. \& Osleger, D. 2002. Carbon cycling perturbation through the Lower-Middle Cambrian boundary interval and olenelloid biomere extinction as revealed by $\delta^{13} \mathrm{C}_{\text {org. }}$. Geological Society of America, 2002 Annual meeting, Abstracts with Programs 34(6), 413.

Naimark, E.B. 2008. Morphogenez predstaviteley roda Peronopsis Hawle et Corda (Agnostina). Paleontologicheskiy Zhurnal 42(4), 53-64 [also Palaeontological Journal 42(4), 389-400].

Naimark, E.B., Shabanov, Y. \& Korovnikov, I. 2011. Cambrian trilobite Ovatoryctocara Tchernysheva, 1962 from Siberia. Bulletin of Geosciences 86(3), 405-422.

DOI 10.3140/bull.geosci.1272

Neltner, L. 1938. Etudes géologiques dans le Sud marocain (Haut Atlas et Anti-Atlas). Notes et Mémoirs de la Service des Mines et Carte géologique du Maroc 42, 1-298.

ÖPIK, A.A. 1956. Cambrian geology of the Northern Territory, 25-54. In Rodgers, J. (ed.) El sistema Cámbrico, su paleogeografía y el problema de su base. Part II (Australia, America). XX Congrès Geologique International, Mexico 1956, Mexico City.

ÖPIK, A.A. 1968. The Ordian Stage of the Cambrian and its Australian Metadoxididae. Bureau of Mineral Resources of Australia, Bulletin 92, 133-166.

ÖPIK, A.A. 1975a. Cymbric Vale Fauna of New South Wales and Early Cambrian Biostratigraphy. Bureau of Mineral Resources of Australia, Bulletin 159(1-4), 1-78.

ÖPIK, A.A. 1975b. Templetonian and Ordian xystridurid trilobites of Australia. Bureau of Mineral Resources, Bulletin 121, 1-84.

OGienKo, L.V., Byalyi, V.I. \& Kolosnitsina, G.R. 1974. Biostratigrafiya kembriyiskikh i ordovikskikh otlozheniy yuga Sibirskoy platformy. 206 pp. Nedra, Moscow.

OGIEnKo, L.V. \& Garina, S.Y. 2001. Stratigrafiya I trilobity kembriya Sibirskoy platformy [Stratigraphy and trilobites of Cambrian of the Siberian Platform]. 380 pp. Nauchniy mir, Moscow. [in Russian].

PALMER, A.R. 1958. Morphology and ontogeny of a Lower Cambrian ptychoparioid trilobite from Nevada. Journal of Paleontology 32, 154-170.

Palmer, A.R. 1964. An unusual Lower Cambrian trilobite fauna from Nevada. U.S. Geological Survey, Professional Paper 483-F, 1-13.

Palmer, A.R. 1968. Cambrian trilobite of east-central Alaska. U.S. Geological Survey, Bulletin 559-B, 1-115.

Palmer, A.R. 1988. Terminal Early Cambrian extinction of the Olenellina: documentation from the Pioche Formation, Nevada. Journal of Paleontology 72, 650-672.
Palmer, A.R. \& Halley, R.B. 1979. Physical stratigraphy and trilobite biostratigraphy of the Carrara Formation (Lower and Middle Cambrian) in the southern Great Basin. United States Geological Survey, Professional Paper 1047, 1-131.

Palmer, A.R. \& James, N.P. 1980. The Hawke Bay Event; a circum-Iapetus regression near the lower Middle Cambrian boundary. Virginia Polytechnic Institute, Department of Geological Sciences, Memoir 2, 15-18.

Palmer, A.R. \& Peel, J.S. 1979. New Cambrian faunas from Peary Land, eastern North Greenland. Rapport Grønlands geologiske Undersøgelse 91, 29-36.

PARnES, A. 1971. Late Lower Cambrian trilobites from the Timna Area and Har 'Amram (Southern Negev, Israel). Israel Journal of Earth Sciences 20, 179-205.

Paterson, J.R. \& Brock, G.A. 2007. Early Cambrian trilobites from Angorichina, Flinders Ranges, South Australia, with a new assemblage from the Pararaia bunyerooensis Zone. Journal of Paleontology 81(1), 116-142.

DOI 10.1666/0022-3360(2007)81[116:ECTFAF]2.0.CO;2

PeEL, J.S. 2010. Articulated hyoliths and other fossils from the Sirius Passet Lagerstätte (early Cambrian) of North Greenland. Bulletin of Geosciences 85, 385-394. DOI 10.3140/bull.geosci.1207

Peel, J.S. \& Ineson, J.R. In press. The Sirius Passet Lagerstätte (early Cambrian) of North Greenland. Palaeontographica canadiana.

Pegel, T.V. 2000. Evolution of trilobite biofacies in Cambrian basin of the Siberian Platform. Journal of Paleontology 74, $1000-1019$.

DOI 10.1666/0022-3360(2000)074<1000:EOTBIC>2.0.CO;2

Peng, J., Zhao, Y.L., Yuan, J.L., Yu, L. \& Hong, Y. 2009. Bathynotus: A key trilobite taxon for global stratigraphic boundary correlation between Cambrian Series 2 and Cambrian Series 3. Progress in Natural Science 19(1), 99-105.

Peng, S.C. \& Babcock, L.E. 2001. Cambrian of the HunanGuizhou region, South China, 3-51. In Peng, S.C., BABCock, L.E. \& Zhu, M.Y. (eds) Cambrian System of South China. University of Science and Technology of China Press, Hefei.

Peng, S.C., Yuan, J.L. \& Zhao, Y.L. 2000. The Taijiangian Stage; a new chronostratigraphic unit for the traditional lower Middle Cambrian in South China. Dicengxue Zazhi [Journal of Stratigraphy] 24(1), 53-54. [in Chinese with English abstract]

QIAN, Y.Y. 1961. Cambrian trilobites from Sandu and Duyun, southern Kweichow. Acta Palaeontologica Sinica 9, 91-129. [in Chinese]

RASETt, F. 1945. Fossiliferous horizons in the "Sillery Formation" near Levis, Quebec. American Journal of Sciences 243(6), 305-319.

RASETTI, F. 1948a. Middle Cambrian trilobites from the conglomerates of Quebec (exclusive of the Ptychoparioidea). Journal of Paleontology 22(1), 1-24. 
RasetTI, F. 1948b. Middle Cambrian trilobites from the conglomerates of Quebec (exclusive of the Ptychoparioidea). Journal of Paleontology 22(3), 315-339.

RASETTI, F. 1951. Middle Cambrian stratigraphy and faunas of the Canadian Rocky Mountains. Smithsonian Miscellaneous Collections 116(5), v + 1-277.

RasetTI, F. 1955. Lower Cambrian ptychopariid trilobites from the conglomerates of Quebec. Smithsonian Miscellaneous Collections 128(7), 1-35.

RasetTi, F. 1963. Middle Cambrian ptychoparioid trilobites from the Conglomerates of Quebec. Journal of Paleontology 37(3), 575-594.

RasetTI, F. 1967. Lower and Middle Cambrian trilobite faunas from the Taconic sequence of New York. Smithsonian Miscellaneous Collections 152(4), 1-111.

Rasetti, F. \& Theokritoff, G. 1967. Lower Cambrian agnostid trilobites of North America. Journal of Paleontology 41, 189-196.

REED, F.R.C. 1910. The Cambrian fossils of Spiti. Memoirs of the Geological Survey of India, Palaeontologia Indica 15(7), Memoir 1, 1-76.

Repina, L.N., Khomentovskiy, V.V., Zhuravleva, I.T. \& RoZANov, A.Y. 1964. Biostratigrafiya nizhnego kembriya SayanoAltayskoy skladchatoj oblasti [Biostratigraphy of the Lower Cambrian of the Sayan-Altay fold region]. Akademiya Nauk SSSR, Sibirskoe otdelenie, Trudy Instituta geologii i geofiziki. 363 pp. Nauka, Moscow.

RESSER, C.E. 1936. Second contribution to nomenclature on Cambrian trilobites. Smithsonian Miscellaneous Collections 95(4), $1-29$.

RESSER, C.E. 1937. Third contribution to nomenclature on Cambrian trilobites. Smithsonian Miscellaneous Collections 95(22), 1-59.

Resser, C.E. 1939. The Ptarmigania strata of the northern Wasatch Mountains. Smithsonian Miscellaneous Collections 98(24), 1-72.

Resser, C.E. \& Howell, B.F. 1938. Lower Cambrian Olenellus Zone of the Appalachians. Bulletin of the Geological Society of America 49, 195-248.

RoBison, R.A. 1976. Middle Cambrian trilobite biostratigraphy of the Great Basin, 39-50. In Robison, R.A. \& Rowell, A.J. (eds) Paleontology and depositional environments: Cambrian of western North America. Brigham Young University Geology Studies 23(2).

Robison, R.A. 1984. Cambrian Agnostida of North America and Greenland. Part I, Ptychagnostidae. University of Kansas Paleontoleontological Contributions, Paper 109, 1-59.

Romanenko, M.F. \& Romanenko, E.V. 1962. Trilobity suyarykskoy svity srednego kembriya Gornogo Altay. Materialy po geologii zapadnoy Sibirskogo kraya 63, 16-29.

Rozanov, A.Y., Zhu, M.Y., Pak, K.L. \& Parkhaev, P.Y. 2008. 2-y Kitaysko-Rossiyskiy simpozium po raschleneniyu nizhnego kembriya. Paleontologicheskiy Zhurnal 2008(4), 1-6.

Savitskiy, V.E., Shabanov, Y.Y., Evtushenko, V.M. \& ShishKIN, B.B. 1972. Opornyy razrez kembriya Khorbusunskoy fatsial'noy oblasti (severo-vostok Sibirskoy platformy), 53-60. In Sukhov, S.V. \& Krasnov, V.I. (eds) Materialy po stratigrafii i paleontologii Sibiri. Trudy Sibirskoy nauchnoissledovatel'skiy institut geologii, geofiziki $i$ mineral'nogo syr'ya (SNIIGGiMS) 146. Novosibirsk.

Savitskiy, V.E., Yevteshenko, V.M., Egorova, L.I., KontoRovitch, A.E. \& Shabanov, Y.Y. 1972. Kembriy Sibirskoy platformy (Yudomo-Olenekskiy tip razreza. Kuonamskiy kompleks otlozheniy). Trudy Sibirskoy nauchno-issledovatel'skiy institut geologii, geofiziki i mineral'nogo syr'ya (SNIIGGiMS) 130. 199 pp. Nedra, Moscow.

Semashкo, A.K. 1969. Novye srednekembriskivkie trilobiti peschano-slantsevoi tolshchi rayona Rudinka yuliya (Batenevskiy Kryazh). Proceedings of Tomsk Polytechnic Institute 196, 71-76. [in Russian]

Shabanov, Y.Y., Korovnikov, I.V., Pereladov, V.S. \& Fefelov, A.F. 2008a. Excursion 1. The traditional Lower-Middle Cambrian boundary in the Kuonamka Formation of the Molodo River section (the southeastern slope of the Olenek Uplift of the Siberian Platform) proposed as a candidate for GSSP of the lower boundary of the Middle Cambrian and its basal (Molodian) stage, defined by the FAD of Ovatoryctocara granulata, 8-59. In The Cambrian System of the Siberian Platform. Part 2: North-East of the Siberian Platform. XIII International Field Conference of the Cambrian Stage Subdivision Working Group, Yakutia, Russia, July 20 - August 1, 2008. PIN, RAS, Moscow, Novosibirsk.

Shabanov, Y.Y., Korovnikov, I.V., Pereladov, V.S., PaK, K.L. \& Fefelov, A.F. 2008b. Kuonamka Formation section on Molodo River - a candidate for global stratotype of the lower boundary of the Middle Cambrian (East of the Siberian Platform). Cambrian Sections of the Siberian Platform - a candidate for statotypes of subdivisions of the International Stratigraphical scheme (stratigraphy and paleontology), 59-70. In Materials for 13 International Field Conference of the Cambrian Stage Subdivision Working Group, Novosibirsk. Sb. RAS, Moscow, Novosibirsk.

Shergold, J.H. 1995. Timescales 1. Cambrian. Australia Phanerozoic timescales, biostratigraphic charts and explanatory notes ( $2^{\text {nd }}$ series). Australian Geological Survey Organisation, Record 1995/30, 1-32.

Shergold, J.H. \& Whittington, H.B. 2000. The Cambrian trilobite Bathynotus (?Redlichioidea) in the Northern Territory, Australia. Alcheringa 24, 1-10.

DOI 10.1080/03115510008619519

SundBerg, F.A. 2004. Cladistic analysis of Early-Middle Cambrian kochaspid trilobites (Ptychopariida). Journal of Paleontology 78(5), 920-940.

DOI 10.1666/0022-3360(2004)078<0920:CAOECK>2.0.CO;2

SunDBERG, F.A. 2007. Nightmare on Resser Street - dealing with Resser's trilobite taxonomy, 213-224. In Mikulic, D.G., LAnding, E. \& Kluessendorf, J. (eds) Fabulous Fossils - 300 Years Of Worldwide Research On Trilobites. University of the State New York, The State Education Department, Albany, NY. 
SundBerg, F.A. 2009. Placement of the Stage 5, Series 3 GSSP (approximately the "Lower-Middle" Cambrian boundary): an update, 90-91. In Smith, M.R., O'Brien, L.J. \& CARON, J.-B. (eds) Walcott 2009. International Conference on the Cambrian Explosion. Abstract volume.

Sundberg, F.A. \& McCollum, L.B. 1997. Oryctocephalids (Corynexochida: Trilobita) of the Lower-Middle Cambrian boundary interval from California and Nevada. Journal of $\mathrm{Pa}$ leontology 71, 1065-1090.

Sundberg, F.A. \& McCollum, L.B. 2000. Ptychopariid trilobites of the Lower-Middle Cambrian boundary interval, Pioche Shale, southeastern Nevada. Journal of Paleontology 74(4), 604-630.

DOI 10.1666/0022-3360(2000)074<0604:PTOTLM>2.0.CO;2

Sundberg, F.A. \& McCollum, L.B. 2003. Early and Mid Cambrian trilobites from the outer-shelf deposits of Nevada and California, USA. Palaeontology 46, 945-986.

Sundberg, F.A., McCollum, L.B., Yuan, J.L. \& Zhao, Y.L. 1999. The near synchronicity of trilobite extinctions at the traditional Lower-Middle Cambrian boundary of eastern Gondwana and Laurentia. Geological Society of America, 1999 Annual Meeting, Abstracts with Programs 31(7), 465.

Sundberg, F.A., Zhao, Y.L., Yuan, J.L. \& Lin, J.P. 2011. Detailed trilobite biostratigraphy across the proposed GSSP for Stage 5 ("Middle Cambrian" boundary) at the WuliuZengjiayan section, Guizhou, China. Bulletin of Geosciences 86(3), 423-464. DOI 10.3140/bull.geosci.1211

Terfelt, F. \& Butterfield, N.J. 2010. A new record of the important Cambrian genus Ovatoryctocara Tchernysheva, 1962 from the Series 2-Series 3 boundary interval, Mount Cap Formation, Mackenzie Mountains, northwestern Canada, 25. In FAtKa, O. \& Budil, P. (eds) The $15^{\text {th }}$ Field Conference of the Cambrian Stage Subdivision Working Group, International Subcommission on Cambrian Stratigraphy. Abstracts and Excursion Guide, Prague, Czech Republic and south-eastern Germany. Czech Geological Survey, Prague.

TomashrolskayA, V.D. \& KarPinSKIY, R.B. 1962 (dated 1961). O nakhodke srednekembriyskikh trilobitov v rayone derevni Verkhney Yerby (Batenevsky kryazh). Tomskogo Politekhnicheskogo Instituta 120, 152-160.

Vinkman, M.K., Gintsinger, A.B., Zhuravleva, I.T., Pegel, T.V. \& Fefelov, A.F. 1980. Stratigraficheskiy ob'em nizhnekembriyskikh otlozheniy na severo-zapadnoy okranie Nagor'ya Sangilen v Tuve, 95-115. In ZhURAVLEVA, I.T. (ed.) Kembriy Altae-Sayanskoy skladchatoy oblasti. Akademiya Nauk SSSR, Sibirskoe otdelenie, Utverzhdeno k pechati Institut geologii i geofiziki. Nauka, Moscow.

Walcott, C.D. 1886. Second contribution to studies on the Cambrian Faunas of North America. Bulletin of the U.S. Geological Survey 30, 727-1095.

Walcott, C.D. 1905. Cambrian faunas of China. Proceedings of the U.S. National Museum 29, 1-106.

WalcotT, C.D. 1908. Cambrian sections of the Cordilleran area. Smithsonian Miscellaneous Collections 53(5), 167-230.

WalcotT, C.D. 1912. Middle Cambrian Branchiopoda, Malaco- straca, Trilobita and Merostomata. Smithsonian Miscellaneous Collections 57, 145-228.

WaLcotT, C.D. 1916a. Cambrian geology and palaeontology 3. Cambrian trilobites. Smithsonian Miscellaneous Collections 64(3), 157-258.

WaLCotT, C.D. 1916b. Cambrian geology and palaeontology 3. Cambrian trilobites. Smithsonian Miscellaneous Collections 64(5), 303-457.

WALCotT, C.D. 1917. Cambrian geology and palaeontology IV. Fauna of the Mount Whyte Formation. Smithsonian Miscellaneous Collections 67, 61-114.

WANG, Y. (ed.) 1964. Handbook of index fossils of South China. 173 pp. Science Press, Beijing. [in Chinese]

WeBster, M. 2009. Systematic revision of the Cambrian trilobite Bathynotus Hall, 1860, with documentation of new occurrences in western Laurentia and implications for intercontinental biostratigraphic correlation. Memoirs of the Association of Australasian Palaeontologists 37, 369-406.

Whittington, H.B. 1988. Hypostomes and ventral cephalic sutures in Cambrian trilobites. Palaeontology 31(3), 577-609.

Wotte, T., Álvaro, J.J., Shields, G.A., Brown, B., Brasier, M.D. \& VeIzer, J. 2007. C-, O- and Sr-isotope stratigraphy across the Lower-Middle Cambrian transition of the Cantabrian Zone (Spain) and the Montagne Noire (France), West Gondwana. Palaeogeography, Palaeoclimatology, Palaeoecology 256, 47-70.

Wotte, T., Strauss, H. \& Sundberg, F.A. 2011. Carbon and sulfur isotopes from the Cambrian Series 2-Cambrian Series 3 of Laurentia and Siberia, 43-63. In Hollingsworth, J.S., SundBerg, F.A. \& Foster, J.R. (eds) Cambrian stratigraphy and paleontology of northern Arizona and southern Nevada. The $16^{\text {th }}$ Field Conference of the Cambrian Stage Subdivision Working Group, International Subcommission on Cambrian Stratigraphy, Flagstaff, Arizona, and southern Nevada, United States. Museum of Northern Arizona Bulletin 67.

YANG, R.D., Zhu, L.J.N. \& WANG, S.J. 2003. Negative carbon isotopic excursion on the Lower/Middle Cambrian boundary of Kaili Formation, Taijiang County, Guizhou Province, China: Implications for mass extinction and stratigraphic division and correlation. Science in China, Series D 46(9), 872-881.

Yegorova, L.I. 1967. Nekotorye trilobity nizhnego i srednego kembriya Sibirskoy platformy. Paleontologicheskiy Zhurnal 1967(1), 68-78.

Yegorova, L.I., Hsiang, L.W., Lee, S.C., NAn, J.S. \& Kuo, Z.M. 1963. Cambrian trilobites from Kweichou and western Hunan. Special Publication of the Chinese Academy of Geological Sciences, Series B, Stratigraphy and Palaeontology 3, 1-88. [in Chinese]

Yegorova, L.I. \& SAVITSKy, V.E. 1969. Stratigrafiya i biofatsii kembriya Sibirskoy platformy (Zapadnoe Prianabar'e). Trudy Sibirskoy nauchno-issledovatel'skiy institut geologii, geofiziki i mineral'nogo syr'ya (SNIIGGiMS) 43. 407 pp. Nedra, Moscow. 
Yegorova, L.I., Shabanov, Y.Y., Rozanov, A.Y., Savitskiy, V.E., Chernysheva, N.E. \& Shishrin, B.B. 1976. Elanskiy $i$ kuonamskiy fatsiostratotipy nizhney granitsy srednego kembriya Sibiri. Trudy Sibirskoy nauchno-issledovatel'skiy institut geologii, geofiziki i mineral'nogo syr'ya (SNIIGGiMS) 211. 168 pp. Nedra, Moscow.

Yin, G.Z. \& LeE, S.J. 1978. Trilobita, 385-594. In Stratigraphy and Palaeontology Work Team (eds) Atlas of fossils of southwest China. Guizhou province. 1. Cambrian to Devonian. Geological Publishing House, Beijing. [in Chinese]

Young, G.A. \& Ludvigsen, R. 1989. Mid-Cambrian trilobites from the lowest part of the Cow Head Group, western Newfoundland. Geological Survey of Canada Bulletin 392, 1-49.

Yuan, J.L., Zhao, Y.L., Wang, Z.Z., Zhou, Z. \& Chen, X.Y. 1997. A preliminary study on Lower-Middle Cambrian boundary and trilobite fauna at Balang, Taijiang, Guizhou, South China. Acta Palaeontologica Sinica 36(4), 494-514. [in Chinese with English abstract]

YuAn, J.L. \& LI, Y. 1999. Lower-Middle Cambrian boundary and trilobite fauna at Laoyingshan, Huainan, Anhui. Acta Palaeontologica Sinica 38(4), 407-422. [in Chinese with English summary]

YuAN, J.L. \& ZHAO, Y.L. 1999. [Subdivision and correlation of Lower Cambrian in Southwest China, with a discussion of the age of Early Cambrian Series Biota]. Acta Palaeontologica Sinica 38 (Supplement), 116-131. [in Chinese]

YUAN, J.L., ZHAO, Y.L. \& LI, Y. 2001. Biostratigraphy of oryctocephalid trilobites. Acta Palaeontologica Sinica 40 (Supplement), 143-156.

Yuan, J.L., Zhao, Y.L., Li, Y. \& HuAnG, Y.Z. 2002. Trilobite fauna of the Kaili Formation (uppermost Lower Cambrian-lower Middle Cambrian) from southeastern Guizhou, South China. 422 pp. Earth, Shanghai Scientific and Technical Publisher, Shanghai. [in Chinese with English summary]

YuAn, J.L., ZhaO, Y.L. \& YANG, X.L. 2006. Speciation of the genus Arthricocephalus Bergeron, 1899 (Trilobita) from the late Early Cambrian and its stratigraphic significance. Progress in Natural Science 16(6), 614-623.

Yuan, J.L., Zhao, Y.L., Peng, S.C., Babcock, L.E., Peng, J., Lin, J.P., GuO, Q.J. \& WANG, Y.X. 2007. New data on the WuliuZengjiayan section (Balang, South China), GSSP candidate for the base of Cambrian Series 3. Memoirs of the Association of Australasian Palaeontologists 33, 57-65.

Yuan, J.L., ZhaO, Y.L., Peng, J., Zhu, X.J. \& Lin, J.P. 2009. Cambrian trilobite Ovatoryctocara granulata Tchernysheva, 1962 and its biostratigraphic significance. Progress in Natural Science 19(2), 213-221.

Zhang/Chang, Q. \& Li, C. 1984. Cambrian trilobites from Guizhi, Gaotan, Anhui, China. Nanjing Institute of Geology and Mineralogy, Chinese Geological Publications 5(4), 78-84.

ZHANG, Q.Z. \& ZHOU, Z.M. 1985. Early Cambrian trilobite fauna of Kunshan, Jiangsu. Acta Palaeontologica Sinica 24, 259-266. [in Chinese with English summary]
Zhang, T. 1981. Trilobita, 134-213. In Geological Bureau of Xinjiang (ed.) Palaeontological Atlas of Northwest China, Xinjiang, vol. 1. Geological Publishing House, Beijing. [in Chinese]

Zhang, W.T. 1985. Synonyms of Ordovician and Cambrian trilobites. Palaeontologica Cathayana 2, 177-178.

Zhang, W.T. 1989. World Cambrian biogeography. Chinese Academy of Science, Developments in Geoscience, Contributions to the $28^{\text {th }}$ International Geological Congress 1989 Washington, 209-220.

Zhang, W.T. 2003. Cambrian biostratigraphy of China, 55-119. In Zhang, W.T., Chen, P.J. \& Palmer, A.R. (eds) Biostratigraphy of China. Science Press, Beijing.

Zhang, W.T., Lu, Y.H., Zhu, Z.L., Qian, Y.Y., Lin, H.L., Zhou, Z.Y., Zhang, S.G. \& YuAN, J.L. 1980. Cambrian trilobite faunas of southwestern China. Palaeontologica Sinica 159, New Series B 16, 1-497. [in Chinese with English summary]

Zhao, Y.L., Gong, X. \& Huang, Y. 1990. A new species of Bathynotus from Lower Cambrian Kaili Formation, Taijiang, Guizhou, China. Journal of the Guizhou University of Technology 16(1), 43-47. [in Chinese with English summary]

ZhaO, Y.L., Huang, Y.Z., Gong, X.Y. \& DaI, X.C. 1990. Bathynotus from Kaili Formation (Lower-Middle Cambrian) of Kaili Area, Guizhou. Acta Palaeontologica Sinica 29(1), 43-53. [in Chinese with English summary]

ZhaO, Y.L., Yu, Y.Y., Yuan, J.L., YANG, X.L. \& GuO, Q.J. 2001b. Cambrian Stratigraphy at Balang, Guizhou Province, China: candidate section for a global unnamed series and stratotype section for the Taijiangian Stage, 189-208. In PENG, S.C., BАвсоск, L.E. \& ZHU, M.Y. (eds) Cambrian system of South China. University of Science and Technology Press, Hefei.

Zhao, Y.L., Yuan, J.L., McCollum, L.B., Sundberg, F.A., YANG, R.D., Guo, Q.J., Zhu, L.J. \& YANG, X.L. 2001a. A potential GSSP for the Lower and Middle Cambrian boundary near Balang Village, Taijiang County, Guizhou Province, China. Acta Palaeontologica Sinica 40 (Supplement), 130-142.

Zhao, Y.L., Yuan, J.L., Peng, S.C., Babcock, L.E., Peng, J., GuO, Q.J., Lin, J.P., TAI, T.S., YANG, R.D. \& WANG, Y.X. 2008. A new section of Kaili Formation (Cambrian) and a biostratigraphic study of the boundary intercal across the undefined Cambrian Series 2 and Series 3 at Jianshan, Jianhe County, China with a discussion of global correlation based on the first appearance datum of Oryctocephalus indicus (Reed, 1910). Progress in Natural Science 18, 1549-1556.

Zhao, Y.L., Yuan, J.L., Peng, S.C., Babcock, L.E., Peng, J., Lin, J.P., Guo, Q.J. \& WANG, Y.X. 2007. New data on the Wuliu-Zhengjiayan section (Balang, South China), GSSP candidate for the base of Cambrian Series 3. Memoir of the Association of Australasian Palaeontologists 33, 57-65.

Zhao, Y.L., Yuan, J.L., Peng, S.C., Guo, Q.L., Zhu, L., Peng, J. \& WANG, P. 2004b. Proposal and prospects for the global Lower-Middle Cambrian boundary. Progress in Natural Science 14, 1033-1038. 
Zhao, Y.L., Yuan, J.L., Peng, S.C., Peng, J., Wang, P.L. \& WANG, Y. 2004a. Oryctocephalus indicus is the best trilobite of FAD of the Middle Cambrian, 32. In CHOI, D.K. (ed.) IX International Conference of the Cambrian Stage Subdivision Working Group, Taebaek, Korea, 16-21 September, 2004, Abstracts with Program.

Zhao, Y.L., Yuan, J.L., Zhang, Z.H., Mao, J.R., Huang, Y.Z., GonG, X.Y. \& WANG, K. 1993. Preliminary study of the Cambrian Kaili Formation and its synchronous strata in transitional area, South China. Journal of Stratigraphy 17, 171-178. [in Chinese]

Zhou, T.M., Liu, Y.R., Meng, X.S. \& Sun, Z.H. 1977. Trilobita. Palaeontological Atlas of Central and South China 1. 470 pp. Geological Publishing House, Beijing. [in Chinese]

Zhou, Z.Y. \& YuAN, J.L. 1980. Lower Cambrian trilobite succes- sion in Southwest China. Acta Palaeontologica Sinica 19(4), 331-339. [in Chinese with English summary]

Zhu, M.Y., BABCock, L.E. \& Peng, S.C. 2006. Advances in Cambrian stratigraphy and paleontology: integrating correlation techniques, palaeobiology, taphonomy and paleoenvironmental reconstruction. Palaeoworld 15, 217-222.

DOI 10.1016/j.palwor.2006.10.016

Zhu, M.Y., Zhang, J.M., Li, G.X. \& YANG, A.H. 2004. Evolution of $\mathrm{C}$ isotopes in the Cambrian of China: implications for Cambrian subdivision and trilobite mass extinctions. Géobios 37, 287-301. DOI 10.1016/j.geobios.2003.06.001

Zhu, M.Y., ZhANG, J. \& YANG, A.H. 2007. Integrated Ediacaran (Sinian) chronostratigraphy of South China. Palaeogeography, Palaeoclimatology, Palaeoecology 254, 7-61. DOI 10.1016/j.palaeo.2007.03.025 